\title{
Qualidade e valorização do camarão sete-barbas (Xiphopenaeus kroyeri, Heller, 1862): aspectos sensoriais e vida útil em gelo
}

\author{
Érika Fabiane Furlan
}

Tese apresentada ao Programa de Pós-graduação em Nutrição em Saúde Pública da Faculdade de Saúde Pública da Universidade de São Paulo para obtenção do título de Doutor em Ciências.

Área de Concentração: Nutrição em Saúde Pública Orientadora: Profa. Dra. Elizabeth A.F.S.Torres

São Paulo 
É expressamente proibida a comercialização deste documento, tanto na sua forma impressa como eletrônica. Sua reprodução total ou parcial é permitida exclusivamente para fins acadêmicos e científicos, desde que na reprodução figure a identificação do autor, do título, instituição e ano da tese. 
Não há escola que se iguale a um lar decente, nem professores que se igualem a pais honestos e virtuosos

(Mahatma Ganthi). 
Aos meus pais, itacyr $e$ Tereza, pelo carinho, credibilidade e principalmente, pela educação e valores proporcionados, que me levam a qualquer lugar.

Aos meus sobrinhos Pedro, Jordano, Julia e Nicoly pelo carinho.

Dedico 


\section{AGRADECIMENTOS}

Primeiramente à Deus, pelas belas oportunidades que coloca em meu caminho.

À colega Rúbia Yuri Tomita, pela orientação e dedicação na realização do projeto de pesquisa Processo FAPESP 10/06525-0, que deu origem a esta Tese e ainda, pela amizade, muito obrigada Rú!!

À Karoline Barbosa, Eduardo Oliveira, Bruno Hara, Marina Carrato, Ana Ramos, Lilia Evans, Thais Farina e André Balbino, pela dedicação, aprendizado e carinho.

À minha orientadora professora Dra Elizabeth Aparecida Ferraz da Silva Torres por me receber de braços abertos nesta renomada instituição que é a FSP, por acreditar no meu potencial, pelo incentivo nas minhas buscas.

Ao Instituto de Pesca/Apta/SAA por toda estrutura disponibilizada para a realização satisfatória desta pesquisa.

A minha equipe de julgadores Gastão Bastos, Luiz Miguel, Ana Ramos, Rúbia Tomita, Camila Ataliba, Acácio Tomás, Juliana Kolling, Natália, Willian Francisco e Thais Farina pela dedicação incansável.

À Faculdade de Saúde Pública da Universidade de São Paulo e seus gentis funcionários sempre dispostos a auxiliar, em especial à Vânia e Alessandra da Seção de PG, Rosana Soares do Laboratório de Nutrição, Márcia e Matheus do comitê de ética, João do financeiro, entre outros que me auxiliaram neste meu percurso.

Aos colegas da Estatística Pesqueira do Instituto de Pesca, em especial Marcus Carneiro, Camila Ataliba e coletores da Baixada Santista, por toda colaboração na definição e viabilização das coletas dos camarões e ainda pelas conversas amistosas.

Ao Dr. Evandro Rodrigues pelas elucidações quanto a espécie alvo do estudo.

À Fundação de Apoio à Pesquisa do Estado de São Paulo - FAPESP pelo apoio financeiro ao projeto FAPESP 10/06525-0

À Coordenação de Aperfeiçoamento de Pessoal de Nível Superior - CAPES pela bolsa concedida para a realização de estágio de doutoramento no exterior.

À Dra. Leonor Nunes do IPIMAR/INRB, I.P. - Lisboa -PT pelo convite a desfrutar do aprendizado junto a sua experiente equipe da Unidade de Investigação de Valorização dos Produtos da Pesca e Aquicultura, muito obrigada pela oportunidade! 
Aos pesquisadores, técnicos e bolsistas do IPIMAR, Tereza Gama Pereira, Suzana Gonçalves, Margarida Muro, Manuel, Marta Sá, Sônia Pedro, Dra. Fernanda, Lena Lourenço, Lena Silva, Cristina Nunes, Tereza Moita, Narcisa Bandarra, entre outros simpáticos colegas, pelo intenso aprendizado em Qualidade do Pescado, bem como, em culinária e cultura portuguesa. Em especial à Dra. Amparo Gonçalves, responsável pelo meu treinamento no QIM-Eurofish, pesquisadora generosa e de excelência, cujos conhecimentos me trouxeram motivação que muito me marcaram na realização deste doutorado. Minha profunda gratidão pela amizade, incentivo contínuo e apoio incansável.

As doutoras Geni Sampaio, Telma Faraldo e Tatiana Saldanha pelos ensinamentos, apoio e amizade.

Às colegas da Unidade Laboratorial de Tecnologia do Pescado, do Instituto de Pesca, Cristiane Rodrigues Pinheiro Neiva, Thais Moron Machado, Marildes Josefina Lemos Neto, pelo estímulo, disposição e colaboração nas mais diferenciadas atividades.

A prof. Dra. Débora Bastos pelas conversas sempre amigáveis e produtivas.

Aos colegas do Instituto Adolfo Lutz Dr. Mário Tavares e Estevão Passos pelo apoio nas análises de clostrídios.

As colegas e amigas da ESALQ/USP Juliana Galvão, Luciana Kimie, Ligianne Shirahigue, Tatiana Pacheco e Lia Ferraz por sempre poder contar com vocês para todas as ??????? profissionais, intelectuais ou não!rs

À Carmem Pestana pelo apoio constante com as questões burocráticas, pela sempre disposição em ajudar e pelo sorriso involuntário.

À minha família em Portugal: Maurício, Alessandra, Miguel, Débora, Toninho, Mônica e Maria pelos momentos incríveis que passamos juntos, pelo cuidado, carinho e longas conversas regadas a um bom vinho português.

Aos meus amigos de todas as horas Priscila Rocha, Maria Augusta, Mariana Daher, Karin Forti, Gica Boni, Eduardo Leal, Ana Paula Galdino e Karin Borges por todo o apoio, torcida e por aquecerem meu coração.

À minha família querida por todo o apoio e compreensão de sempre!! 
Furlan ÉF. Qualidade e valorização do camarão sete-barbas (Xiphopenaeus kroyeri, Heller, 1862): aspectos sensoriais e vida útil em gelo [Tese de Doutorado]. São Paulo: Faculdade de Saúde Pública da USP; 2012

\section{Resumo}

Introdução: Os crustáceos ocupam o quarto lugar em volume de captura no mundo e o seu elevado valor comercial, os tornam relevantes em relação ao montante financeiro gerado pela atividade pesqueira. Atualmente, a garantia da qualidade é requisito para a permanência no mercado, sendo exigida dentro de especificações previamente estabelecidas, tanto pelas autoridades sanitárias brasileiras como dos países para os quais o pescado é exportado. Objetivo: Caracterizar a qualidade dos camarões sete-barbas desembarcados na região Metropolitana da Baixada Santista, visando a segurança alimentar e a sustentabilidade da cadeia produtiva e, a partir do método do índice de qualidade (QIM), desenvolver um protocolo de avaliação do frescor para o camarão marinho Xiphopenaeu kroyeri inteiro armazenado em gelo. Métodos: Após o levantamento dos principais pontos de desembarque do camarão sete-barbas na região Metropolitana da Baixada Santista, SP., considerando a produção e frota pesqueira; realizou-se a caracterização da qualidade do camarão desembarcado na região pela determinação da biometria e dos parâmetros físicos, químicos e microbiológicos regulados $(\mathrm{pH}$, bases nitrogenadas voláteis totais (BNVT), trimetilamina (TMA), residual de dióxido de enxofre, mercúrio e pesquisa de Staphylococcus aureus e Salmonella spp). Foi realizada a determinação instrumental de cor e textura; a quantificação das substâncias reativas ao ácido tiobarbitúrico (TBARS), as contagens de coliformes totais e termotolerantes, de clostrídios sulfito redutores e testes sensoriais de aceitação. Para otimizar o protocolo de avaliação do frescor do camarão X. kroyeri armazenado em gelo, com e sem o uso de sulfito, foram conduzidos ensaios de vida útil empregando-se as análises física e químicas (pH, BNVT, TMA, TBARS e aminas biogênicas), microbiológicas (S.aureus, Salmonella spp, coliformes totais, bolores e leveduras, contagens padrão 
de bactérias heterotróficas aeróbias psicrotróficas e mesófilas) e testes sensoriais, onde se utilizou o protocolo elaborado. Resultados: A análise global dos parâmetros de qualidade de 20 desembarques mostra que os camarões apresentavam-se em desacordo com os limites propostos pelo Regulamento de Inspeção Industrial e Sanitária de Produtos de Origem Animal, embora atendessem aos padrões microbiológicos do Ministério da Saúde e, em alguns casos, foram qualificados sensorialmente como "muito bons". Indicando a necessidade de adequação dos limites estipulados para os parâmetros físico e químicos nacionais vigentes para o consumo do camarão sete-barbas. Os padrões de coloração para a espécie parecem bem promissores, mas devem ser mais estudados, frente a gama de fatores que afetam a mesma. A rejeição sensorial do produto sem sulfito ocorreu primeiro, pelo escurecimento do cefalotórax do camarão (melanose) no $2^{\circ}$ dia de armazenamento em gelo, tanto para o produto cru como para o cozido. A eficiência do uso de sulfitos, em solução a $1,25 \%$, na conservação do camarão foi indicada pela rejeição sensorial que ocorreu com 3 ou 4 dias e foi determinada pela presença de odores não característicos (amoniacal, ácido e/ou sulfídrico) no camarão cozido, os quais apresentaram correlação com o período de armazenamento em gelo ( $\mathrm{r}=0,70 ; \mathrm{p}<$ 0,05). O limite residual de dióxido de enxofre em camarões provenientes de pescas longas (3 a 10 dias) apresentou-se sempre acima do limite permitido pela Agência Nacional da Vigilância Sanitária, confirmando que o uso do metabissulfito de sódio para retardar o aparecimento da melanose, deve ser cauteloso, com vistas a não causar prejuízos à saúde do consumidor. A regressão linear dos parâmetros sensoriais propostos no protocolo QIM (cor, odor, melanose, aderência do cefalotórax ao corpo e aderência da carapaça) mostrou a correlação dos mesmos com o período de estocagem em gelo, tanto para os camarões do controle, como para os tratados com sulfito. Conclusão: Com vistas à classificação de um lote de camarão sete-barbas como aceitável para o consumo são sugeridos os seguintes limites: $\mathrm{pH} \leq 7,7$; BNVT $\leq 35 \mathrm{mg} .100 \mathrm{~g}^{-1}$ de músculo; firmeza muscular (entre os 2 primeiros segmentos da cauda) > $6 \mathrm{~N}$, sendo desejável valores superiores para o camarão recém desembarcado. Há necessidade de melhorias nas práticas a bordo das embarcações pesqueiras. O protocolo QIM para o camarão X.kroyeri inteiro e conservado em gelo, 
consiste de 5 parâmetros e seus descritores, os quais somam 11 pontos de demérito e pode ser utilizado em camarões tratados ou não com sulfitos.

Descritores: Crustáceos, Sete-barbas, Segurança do alimento, Índice de Qualidade, Sulfitos. 
Furlan ÉF. Quality and value added for seabob shrimp (Xiphopenaeus kroyeri, Heller, 1862): sensory aspects and shelf life on ice [Thesis]. Sao Paulo (BR): School of Public Health of University of São Paulo; 2012

\section{Abstract}

Introduction: Crustaceans occupy the fourth place in world capture volume and their high economic value makes them relevant fishery activity in the market share. Nowadays, quality assurance is a mandatory requirement to be kept in market, due specific established requirements from national sanitary authorities or from imported countries. Objectives: Characterize the quality of the seabob-shrimp landed in Santos, SP (BR), to food security and sustainability of supply chain and, using the quality index method (QIM) to develop a protocol for freshness evaluation of Raw whole Xiphopenaeus kroyeri shrimp stored on ice. Methods: After the assessment of the main landing points of the seabob-shrimp in the metropolitan area of Santos, SP (BR), considering the production and shipping fleet; the characterization of the shrimp quality landed in the region was carried out by biometry determination and physical, chemical and regulated microbiological parameters $(\mathrm{pH}$, total volatile basic nitrogen (TVB-N), trimethylamine (TMA), sulfur dioxide residue, mercury, $S$. aureus and Salmonella spp,). Instrumental determination of the color and texture, substances thiobarbituric acid reactive quantification (TBARS), total and fecal coliforms counts, Clostridium sulfide reductors and sensory acceptance tests were also performed. To optimize the protocol for the evaluation of ice stored X. kroyeri shrimp freshness, treated or not with sulfite, trials of shelf life were conducted using physical and chemicals analyzes (pH, TVB-N, TMA, TBARS and biogenic amines), microbiological (S.aureus, Salmonella spp, total coliforms counts, molds and yeasts, Mesophilic and Psychrotrophic Bacteria) and sensory analysis, where established protocol was used. Results: Overall analysis of the quality parameters of 20 landings has shown that the shrimps were in disagreement with limits proposed by the Regulation of Industrial and Sanitary Inspection of Animal Products, although the 
microbiological standards requirements of the Ministry of Health were attended and, in some cases, were sensorially qualified as "very good". This implies the necessity of physical and chemical parameters adequacy for the current national seabob-shrimp consumption. The staining patterns for the species look very promising, but should be further studied, since the great range of factors that affect it. The sensory rejection of products without sulfite occurred first with a darkening of the shrimp carapace (melanosis) in the 2nd day of storage on ice, as much to the crude product as cooked one. The efficiency of the sulphites, in solution at $1.25 \%$, in the seabob-shrimp conservation was indicated by the sensory rejection that occurred in 3 or 4 days and was determined by the presence of uncharacteristic odors (ammonia, acid and/ or hydrogen sulfide) in cooked shrimp, that showed correlation with ice storage period $(\mathrm{r}=0.70, \mathrm{p}<0.05)$. Results of residual sulfur dioxide in shrimps from long fisheries (3 to 10 days) were always above the limit allowed by ANVISA, which confirms that the usage of sodium metabisulfite to delay the onset of melanosis should be cautious to avoid consumer health. The linear regression of the parameters proposed in the protocol QIM (color, odor, melanosis, adhesion of the cephalothorax and of the carapace to the body) showed a correlation between the period of storage on ice for both, control shrimps and treated with sulphite. Conclusion: In order to classify a batch of seabob-shrimp as acceptable for consumption the following limits are suggested: $\mathrm{pH} \leq 7.7$; TVB-N $\leq 35 \mathrm{mg} .100 \mathrm{~g}-1$ of muscle; muscle firmness (between the first and second segment of tail) $>6 \mathrm{~N}$, with higher values for freshly landed shrimp. It is necessary to improve practices onboard of fishing vessels. The Quality Index protocol for shrimp X. kroyeri "in natura" consists of five parameters and their descriptors, with total 11 demerit points and can be used in shrimps treated or not with sulfite.

Key-words: Shellfish, Sea-bob, Food safety, Quality Index Method, Sulfite. 


\section{ÍNDICE}

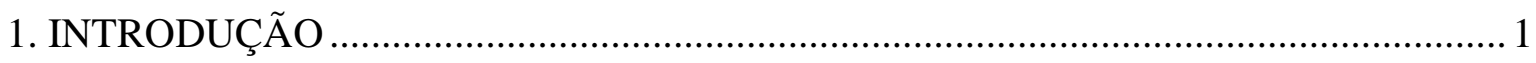

1.1 JUSTIFICATIVA ……………………………………………………………. 2

2. CAPÍTULO 1 - REVISÃO DE LITERATURA ……………………………………...... 4

2.1 PANORAMA DA PRODUÇÃO DE CAMARÕES MARINHOS .............................. 4

2.2 O CAMARÃO Xiphopenaeus kroyeri (Heller, 1862).................................................. 5

2.3 DIAGNÓSTICO DO MERCADO DE CAMARÕES …………………………….....

2.4 QUALIDADE DOS PRODUTOS PESQUEIROS ………….................................. 8

2.4.1 Padrões brasileiros para aferição da qualidade de camarões ...................................................11

2.4.2 Aspecto sensorial do pescado: método do índice de qualidade ................................................ 13

2.4.3 Aspecto microbiológico ................................................................................................ 14

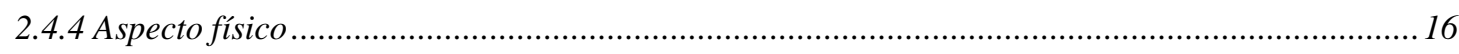

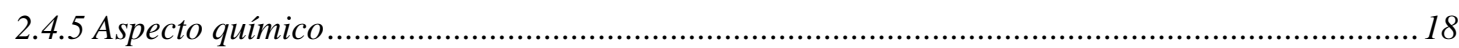

2.5 SEGURANÇA ALIMENTAR NA CADEIA PRODUTIVA DO PESCADO ...........20

2.6 MELANOSE EM CAMARÕES ............................................................................. 22

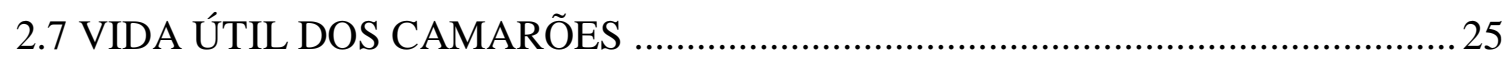

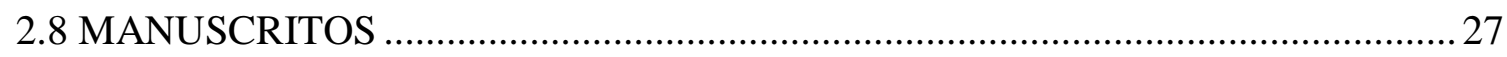

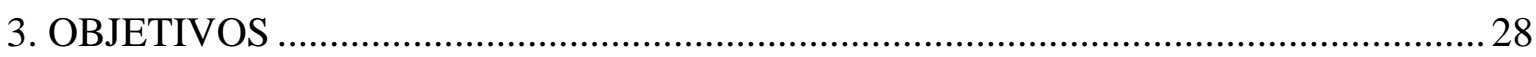

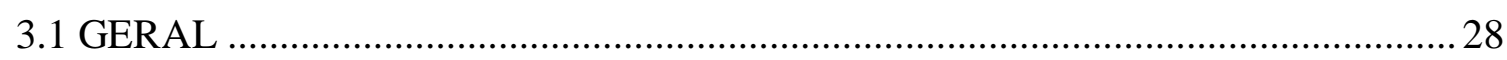

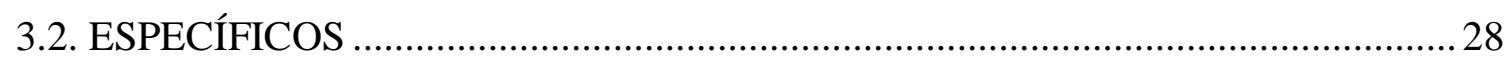

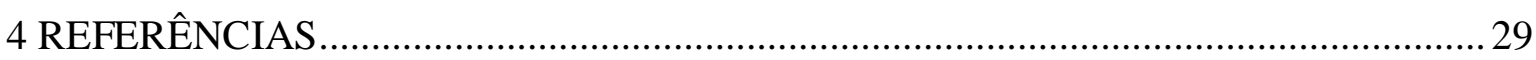

5. CAPÍTULO 2 - QUALIDADE DO CAMARÃO SETE-BARBAS (Xiphopenaeus kroyeri, HELLER, 1862) DESEMBARCADO NA REGIÃO METROPOLITANA DA BAIXADA SANTISTA, SP - BRASIL...................................................................... 41

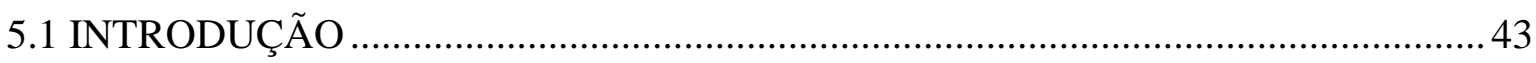

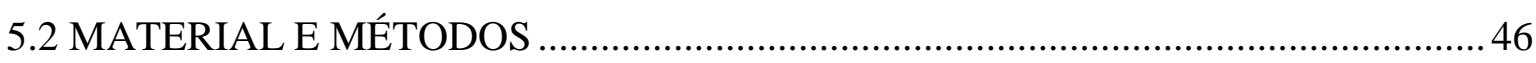

5.2.1 DELINEAMENTO DO ESTUDO …………………....................................... 46

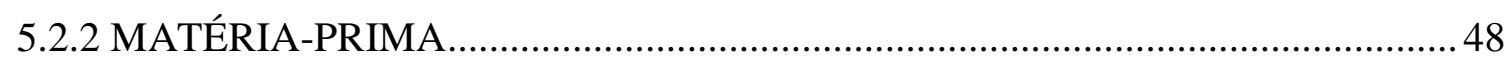

5.2.3 ANÁLISES FÍSICAS, FÍSICO QUÍMICA E QUÍMICAS ....................................49

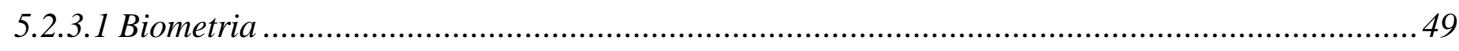

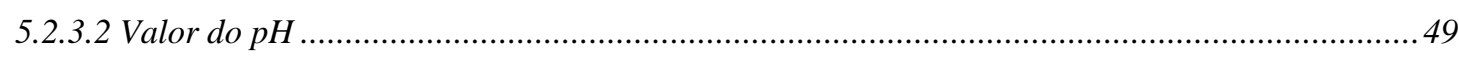


5.2.3.3 Bases Nitrogenadas Voláteis Totais $(B N V T)$.................................................................. 50

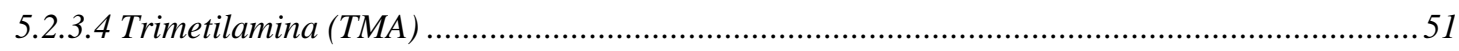

5.2.3.5 Substâncias reativas ao ácido tiobarbitúrico (TBARS) ...........................................................51

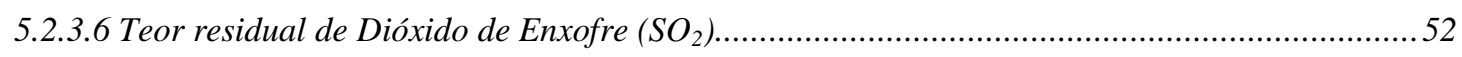

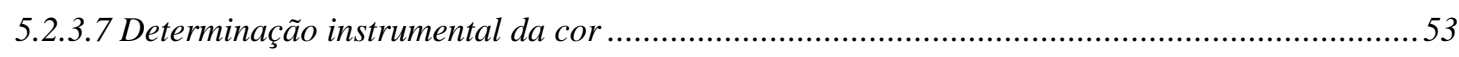

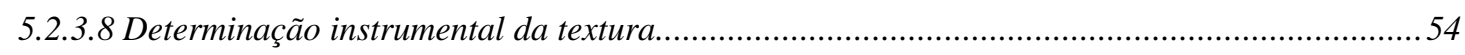

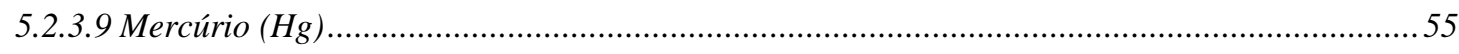

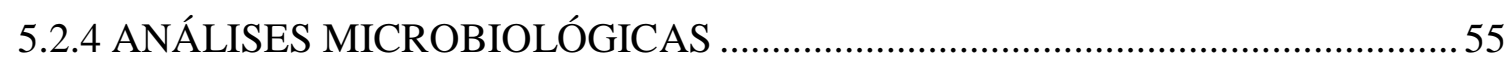

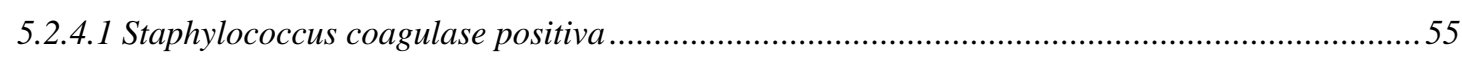

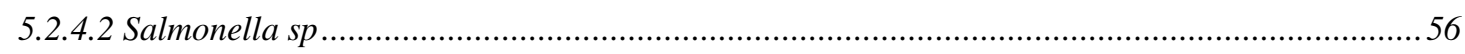

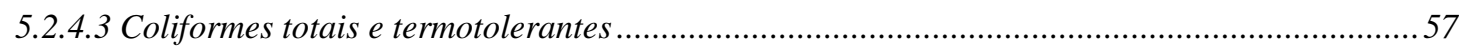

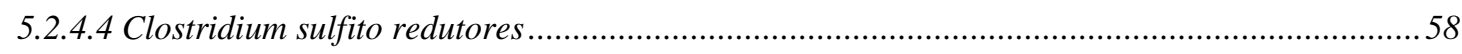

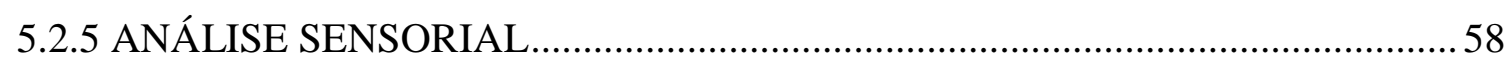

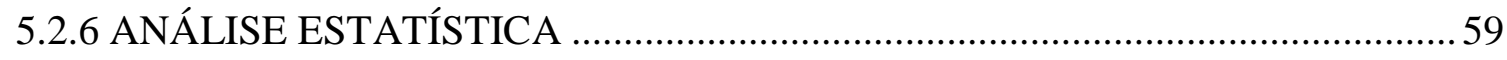

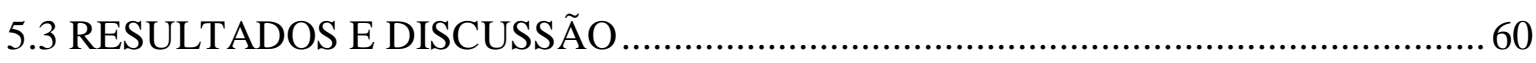

5.3.1 LEVANTAMENTO DOS PRINCIPAIS PONTOS DE DESEMBARQUE DO CAMARÃO Xiphopenaeus kroyeri NO ESTADO DE SÃO PAULO E

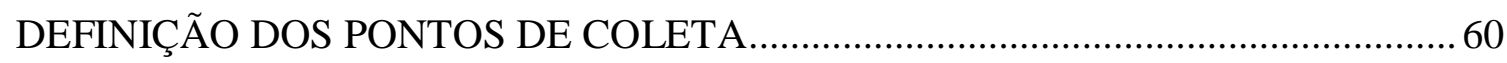

5.3.2 ANÁLISES FÍSICAS, FÍSICO QUÍMICA E QUÍMICAS .....................................62

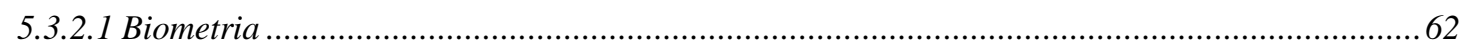

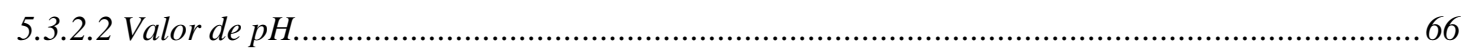

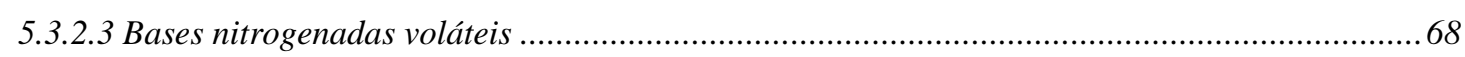

5.3.2.4 Substâncias reativas ao ácido tiobarbitúrico .................................................................... 71

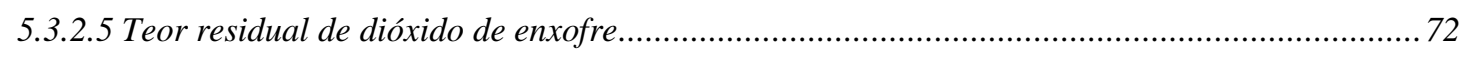

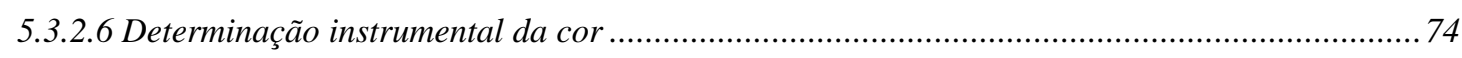

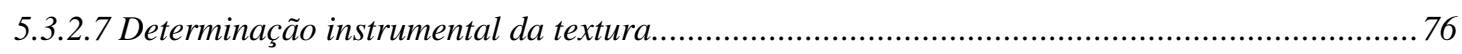

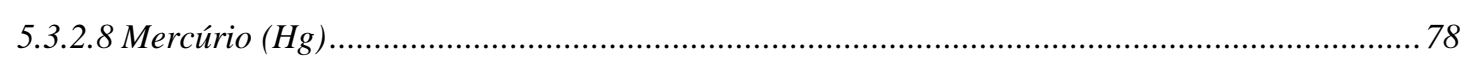

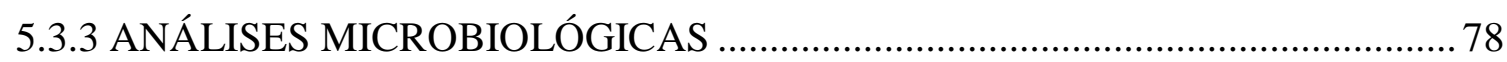

5.3.3.1 Staphylococcus coagulase positiva e Salmonella spp ............................................................... 78

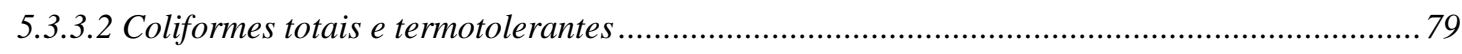

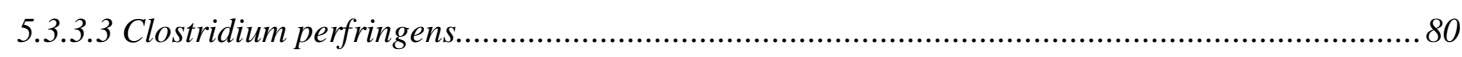

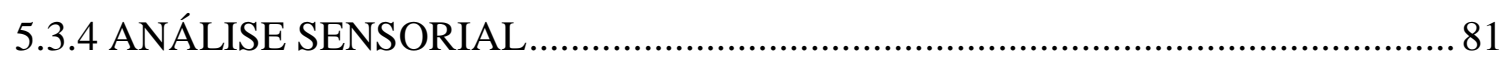

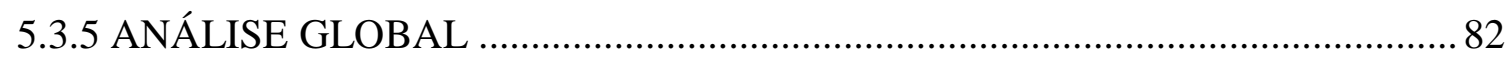

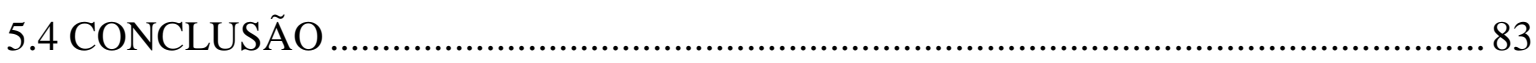

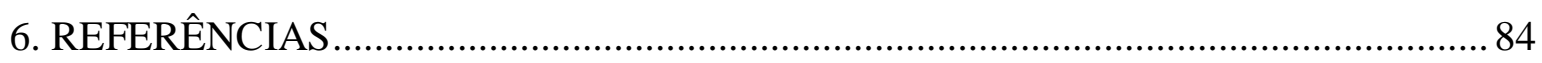


7. CAPÍtUlO 3 - DESENVOLVIMENTO DE PROTOCOLO PARA OTIMIZAÇÃO DA AVALIAÇÃO SENSORIAL DO FRESCOR PARA O CAMARÃO MARINHO Xiphopenaeus kroyeri ARMAZENADO EM GELO..................92

7.1 INTRODUÇÃ

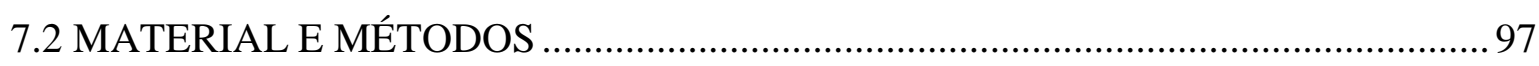

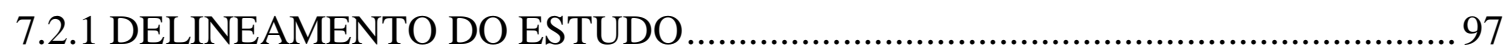

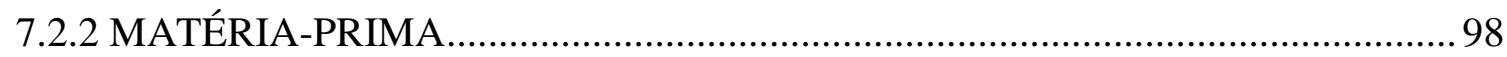

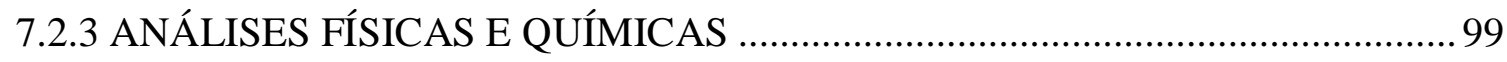

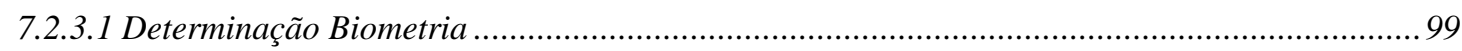

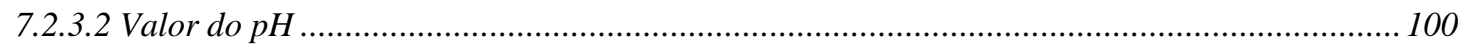

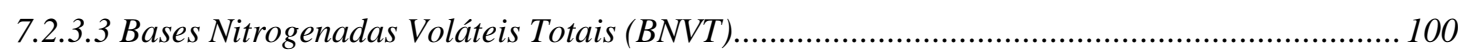

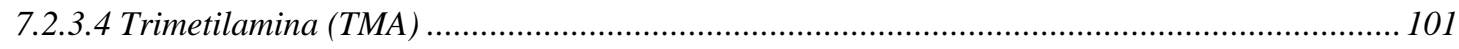

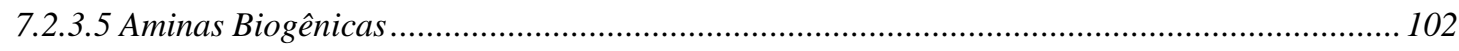

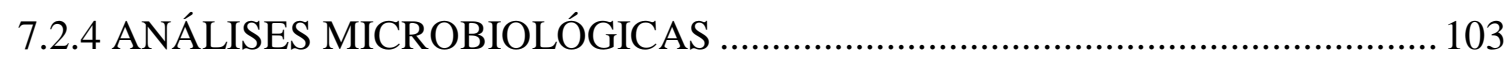

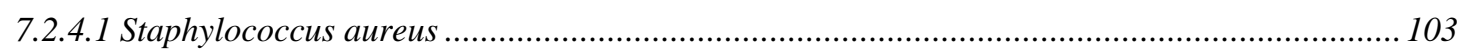

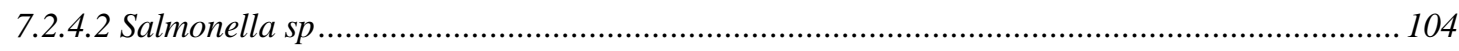

7.2.4.3 Contagem de coliformes totais e termotolerantes ................................................................. 105

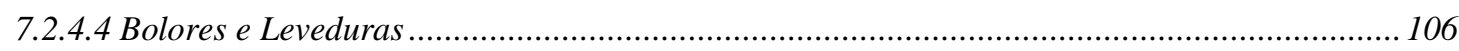

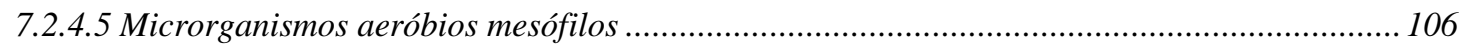

7.2.4.6 Microrganismos aeróbios psicrotróficos ………………………………………................... 107

7.2.5 ANÁLISE SENSORIAL E DESENVOLVIMENTO DO PROTOCOLO

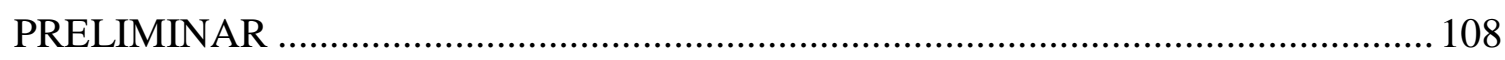

7.2.6 VERIFICAÇÃO DA VIDA ÚTIL E OTIMIZAÇÃO DO PROTOCOLO QIM PARA O CAMARÃO MARINHO Xiphopenaeus kroyeri INTEIRO, ESTOCADO

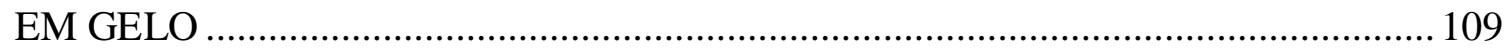

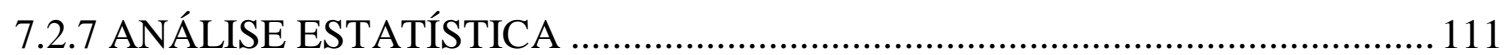

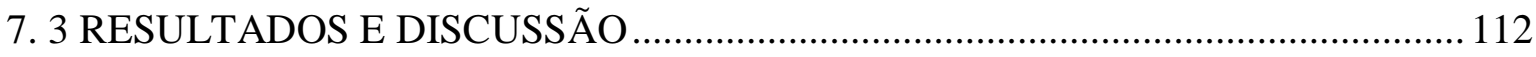

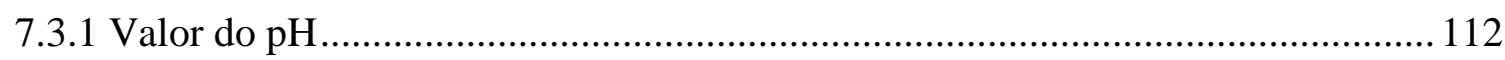

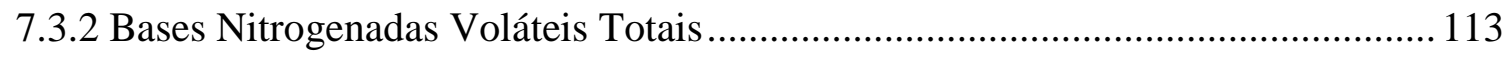

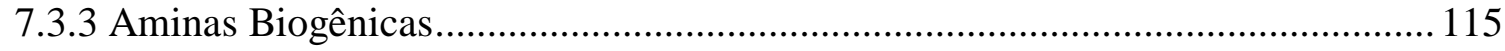

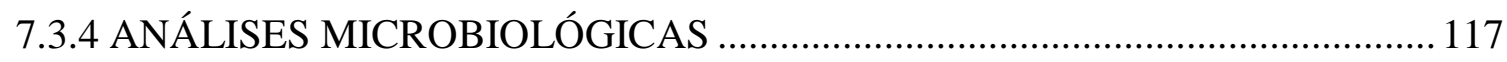

7.3.5 ANÁLISE SENSORIAL E VERIFICAÇÃO DA VIDA ÚTIL DO CAMARÃO Xiphopenaeus kroyeri INTEIRO ESTOCADO EM GELO ...................... 118 


\subsubsection{OTIMIZAÇÃO DO PROTOCOLO QIM PARA O CAMARÃO Xiphopenaeus}

kroyeri INTEIRO ARMAZENADO EM GELO ………………………………........ 120

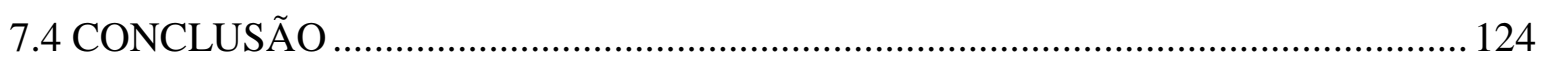

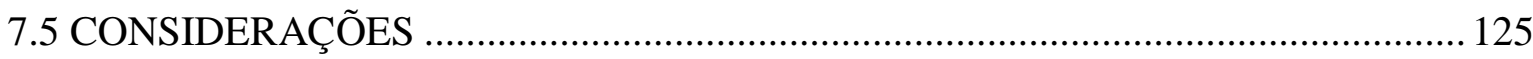

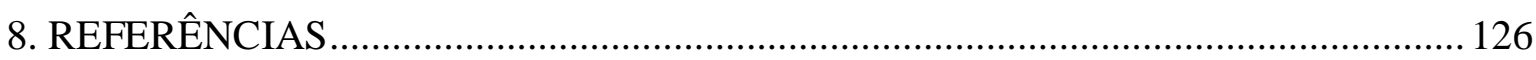

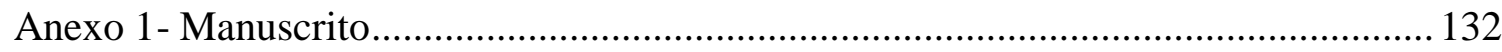

Anexo 2 - Capa do Livro publicado em novembro/2012 - Capítulo 6 - Manuscrito 2.142 Anexo 3 - Ficha da análise sensorial de aceitação do camarão sete-barbas in natura. . 143 Anexo 4 - Ficha de análise sensorial de camarões sete-barbas cozido............................. 144

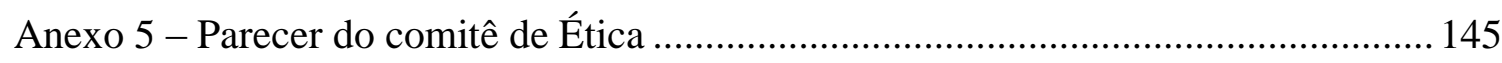

Anexo 6 - Primeira página do Currículo Lattes da aluna ................................................... 146

Anexo 7 - Primeira página do Currículo Lattes da orientadora....................................... 147 


\section{Lista de tabelas}

Tabela 1. Principais espécies de pescado (t) descarregado na Baixada Santista, SP.,

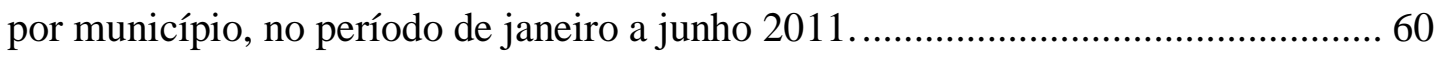
Tabela 2. Comprimento médio $(\mathrm{cm})$ de camarões sete-barbas (X. kroyeri) desembarcados na região metropolitana da Baixada Santista, de outubro/2011 à

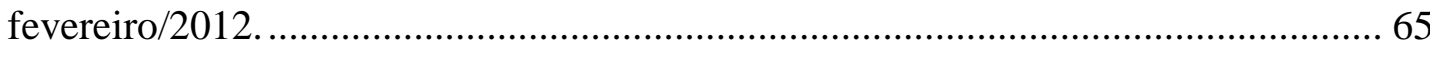
Tabela 3. Valores médios de BNVT, pH, TBARS, residual de SO2, firmeza, mercúrio e aceitação sensorial de camarões X.kroyeri desembarcados na região Metropolitana da Baixada Santista, de outubro de 2011a fevereiro de 2012 ............ 67

Tabela 4. Coeficiente de correlação da coloração de camarões sete-barbas, determinada pelo CIELab sistem, com os parâmetros sensoriais e físico e químico,

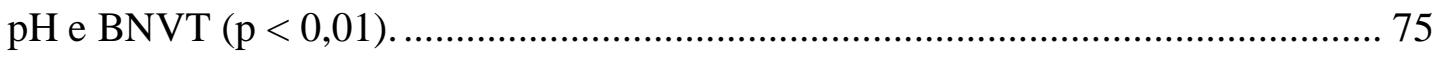




\section{Lista de figuras}

Figura 1. Camarão Xiphopenaeus kroyeri - Extraído de: IBAMA, (2011).

Figura 2. Aspectos da qualidade do pescado. Adaptado de ÓLASFSDÓTTIR et al., (1997).

Figura 3. Fluxograma dos procedimentos para a caracterização da qualidade do camarão sete-barbas desembarcado na Baixada Santista, SP - Brasil 47

Figura 4. Amostras de camarão sete-barbas. 48

Figura 5. Amostra em cápsula preta, colorímetro CR-400 e placa de calibração (branco).

Figura 6. Ilustração de um camarão e destaque da região do corte efetuado para avaliação da textura. 54

Figura 7. Mapa do Estado de São Paulo e abaixo dos municípios da Baixada Santista.

Figura 8. Amostras por município (\%).

Figura 9. Amostras por tipo de pesca $(\%)$.

Figura 10. Camarão sete-barbas colhidos na Baixada Santista, SP., por faixas de comprimento $(\%)$

Figura 11. Dispersão dos valores médios de BNVT $\left(\mathrm{mg} \mathrm{N} 100 \mathrm{~g}^{-1}\right)$ pelo comprimento $(\mathrm{cm})$

Figura 12. Coloração de camarões sete-barbas inteiros (CIELab system), valores médios de $\mathrm{L}^{*} \mathrm{a}^{*} \mathrm{~b}^{*}$.

Figura 13. Camarões sete-barbas com 3 dias de vida útil, tratados com sulfito (esquerda) e sem sulfito (direita).

Figura 14. Procedimentos para a determinação da vida útil do camarão sete-barbas e para desenvolvimento e otimização do protocolo QIM para avaliação do seu frescor.

Figura 15. Lote de camarão sete-barbas in natura.

Figura 16. Preparo da solução de sulfito de sódio. 98

Figura 17. Protocolo de avaliação do frescor do camarão Xiphopenaeus kroyeri armazenado em gelo 
Figura 18. Variação dos valores de $\mathrm{pH}$ de camarões sete-barbas durante armazenamento em gelo

Figura 19. Valores de BNVT em camarões sete-barbas durante armazenamento em gelo.

Figura 20. Valores médios do parâmetro odor não característico (amoniacal, ácido e/ou sulfídrico) detectado no camarão sete-barbas com sulfito, durante o armazenamento em gelo.

Figura 21. Regressão linear entre os valores médios dos parâmetros sensoriais (escore) e o período de armazenamento em gelo do camarão sete-barbas sem sulfito, referentes a 3 ensaios independentes (fevereiro/2012, julho/2012 e agosto/2012, $\mathrm{n}=3)$ 121

Figura 22. Regressão linear entre os valores médios dos parâmetros sensoriais (escore) e o período de armazenamento em gelo do camarão sete-barbas tratado com sulfito (1,25\%), referentes a 3 ensaios independentes (fevereiro/2012, julho/2012 e agosto/2012, $\mathrm{n}=3$ )

Figura 23. Evolução do Índice de Qualidade do camarão sete-barbas inteiro durante o armazenamento em gelo $\left(2 \pm 2^{\circ} \mathrm{C}\right)$, baseado em três ensaios de vida útil independentes. 


\section{Lista de abreviaturas}

ABNT - Associação Brasileira de Normas Técnicas

ADP - Adenosina Difosfato

AM - (Di) Aldeído Malônico

AMP - Adenosina Monofosfato

ANVISA - Agência Nacional da Vigilância Sanitária

AOAC - Association of Official Analytical Chemists

APHA - American Public Health Association

APPCC - Análise de Perigos e Pontos Críticos de Controle

APTA - Agência Paulista de Tecnologia dos Agronegócios.

ATP - Adenosina Trifosfato

BNVT - Bases Nitrogenadas Voláteis Totais

BPM - Boas Práticas de Manipulação

CLAE - Cromatografia Líquida de Alta Eficiência

CLAE/UV - Cromatografia Líquida de Alta Eficiência com gradiente de eluição e detecção ultravioleta

CEBImar - Centro de Biologia Marinha

CFSAN - Center for Food Safety and Applied Nutrition

CNNPA - Comissão Nacional de Normas e Padrões para Alimentos

CONAMA - Conselho Nacional do Meio Ambiente

CSSP - Canadian Shellfish Sanitation Program

DMA - Dimetilamina

DTA - Doença Transmitida por Alimentos

FA - Formaldeído

FAO - Food and Agricultural Organization

FDA - Food and Drug Administration

Hx - Hipoxantina

ICMSF - International Commission on Microbial Specifications for Foods

IEA - Instituto de Economia Agrícola

IMP - Inosina Monofosfato 
INO - Inosina

LANAGRO - Laboratório Nacional Agropecuário

NACMCF - National Advisory Committee on Microbiological Criteria for Foods

NSSP - National Shellfish Sanitation Program

OTMA - Óxido de trimetilamina

PCC - Ponto Crítico de Controle

PMAP - Programa de Monitoramento da Atividade Pesqueira

QIM - Quality Index Method

RIISPOA - Regulamento da Inspeção Industrial e Sanitária de Produtos de Origem

Animal

SAN - Segurança Alimentar e Nutricional

SAA - Secretaria de Agricultura e Abastecimento do Estado de São Paulo

SOFIA - The State of World Fisheries and Aquaculture

TBA - Ácido Tiobarbitúrico

TBARS - Substâncias reativas ao Ácido Tiobarbitúrico

TCA - Ácido Tricloroacético

TMA - Trimetilamina

UFC - Unidade Formadora de Colônia

VHA - Vírus da Hepatite tipo A 


\section{INTRODUÇÃO}

O consumo brasileiro de pescado está em pleno crescimento e o camarão Xiphopenaeus kroyeri (Heller, 1862) foi a segunda principal espécie marinha desembarcada no Estado de São Paulo - Brasil, em 2011 (INSTITUTO DE PESCA, 2011).

Por ser uma espécie costeira, o camarão sete-barbas é acessível à pesca de pequena escala, destacando-se entre as espécies marinhas desembarcadas no Estado de São Paulo em volume capturado e número de embarcações envolvidas na atividade (SEVERINO-RODRIGUES et al., 1993; INSTITUTO DE PESCA, 2011), tendo relevância econômica e social (GRAÇA LOPES et al., 2007).

Os camarões são normalmente comercializados frescos ou congelados. Uma vez capturados estes devem ser imediatamente lavados, classificados por tamanho e pesados. Todo camarão mesmo se comercializado in natura, deve passar por um processo de beneficiamento, seja este primário ou integral. O beneficiamento primário deve ser realizado ainda na embarcação (PINHEIRO; CINTRA, 1999) e o integral deverá ser realizado por uma unidade credenciada pelo Ministério da Agricultura, que obedeça a um sistema de controle da qualidade de Análise de Perigos e Pontos Críticos de Controle (APPCC). A adoção deste critério é exigência dos mercados internacionais e, mais recentemente, nacional e requer, em suma, a implementação de princípios que objetivam prevenir ou eliminar as condições de risco durante a despesca e/ou colheita até o processamento dos camarões (NUNES, 2001).

Após a morte do pescado, as enzimas presentes na carne e vísceras passam a atacar as substâncias do seu próprio corpo. Esta ação, conhecida como autólise, provoca o amolecimento da carne e a produção de odores desagradáveis. Outra consequiência deste fenômeno é o aparecimento de manchas pretas (melanose) em lagostas e camarões, principal agravante para os países que exploram tais recursos, devido as grandes perdas comerciais. 
A inocuidade dos alimentos é fator de preocupação das autoridades sanitárias e consumidores. Essa preocupação recai, entre outros aspectos, sobre a contaminação por produtos químicos, como a presença de agrotóxicos, aditivos e antibióticos.

O uso excessivo de sulfitos para a prevenção da melanose em camarões, a deficiente qualidade do camarão desembarcado e comercializado no Brasil, bem como o impacto da manipulação inadequada levando à contaminação de camarões vem sendo apontados em alguns estudos (THAMPURAN; GOPAKUMAR, 1990; MOURA et al., 2003; OGAWA et al., 2003; YOKOYAMA, 2007; FURLAN; TORRES, 2010; MACHADO et al., 2010; FURLAN et al., 2012).

Aliando estas problemáticas à antiga legislação vigente para pescado (BRASIL, 1952) e à falta de especificidade da mesma frente as várias espécies exploradas comercialmente no país, vê-se a necessidade de desenvolvimento de ferramentas que contribuam para redução dos riscos à saúde associados ao consumo do pescado e que em contrapartida, valorizem a sua qualidade.

\subsection{JUSTIFICATIVA}

O setor pesqueiro brasileiro apresenta carência por métodos de padronização rápida para avaliação da qualidade do pescado e seus produtos. No Brasil, o principal método utilizado pelas indústrias e serviço de inspeção para a avaliação do frescor em pescado in natura ou de produtos derivados é o sensorial, visto que os demais métodos existentes, físico-químicos e microbiológicos, muitas vezes são morosos e/ ou de alto custo.

No entanto, não existe um regulamento técnico de produção, identidade e qualidade para o camarão marinho X. kroyeri, comprometendo a eficácia desta avaliação, embora haja no país uma crescente preocupação em aumentar a oferta de alimentos com condições físicas, químicas e microbiológicas satisfatórias, apresentando assim maior qualidade e segurança. 
Neste contexto, torna-se imprescindível o estabelecimento de uma metodologia eficiente na averiguação da qualidade do camarão $X$. kroyeri, que ofereça informação necessária e de forma simples, viabilizando sua aplicação na rotina dos inspetores e das plantas de processamento.

O Quality Index Method (QIM) é um método rápido e tem sido indicado como referência na padronização e harmonização da avaliação sensorial de pescado na Europa (MARTINSDÓTTIR et al., 2003). Segundo alguns autores o QIM tem se mostrado uma ferramenta útil no planejamento da produção e no trabalho de garantia da qualidade (BREMNER, 1985; HYLDIG; NIELSEN, 2004; NUNES; BATISTA, 2004; ESTEVES; ANÍBAL, 2007). 


\section{CAPÍTULO 1 - REVISÃO DE LITERATURA}

\subsection{PANORAMA DA PRODUÇÃO DE CAMARÕES MARINHOS}

A pesca e aquicultura mundial contribuíram com, aproximadamente, 148 milhões de toneladas do pescado destinado ao consumo humano em 2010, tendo propiciado um consumo médio aparente, per capita, de 18,4 $\mathrm{kg}$ em 2009, o mais alto já registrado. A aquicultura continua sendo o setor de produção de alimentos de origem animal que mais cresce no mundo, enquanto a produção pesqueira mundial tem permanecido estável nas últimas décadas, aproximadamente 90 milhões de toneladas, com exceção do mercado da anchoveta, que é mais suscetível às flutuações em função das condições ambientais (FAO, 2012b).

Segundo o documento The State of World Fisheries and Aquaculture (FAO, 2008) a produção mundial de camarões, capturados e de cultivo, encontra-se ao redor dos 6 milhões de toneladas. O camarão é o produto pesqueiro mais importante comercializado no mercado internacional e a atividade extrativa ainda é a principal responsável pela oferta global do produto (PAIVA; RODRIGUES; AMORIM, 2003; FAO, 2012a).

No mundo inteiro, um pouco menos de 300 espécies de camarão são de interesse econômico. Destes, aproximadamente 100 espécies compõem as principais capturas. Sendo o camarão Acetes japonicus a mais importante espécie em volume no mundo (FAO, 2008).

Globalmente, pouco se conhece quanto ao número de embarcações e profissionais envolvidos na pesca do camarão. Contudo, estatísticas de produção e comércio indicam a importância desta atividade, uma vez que o camarão sete-barbas encontra-se entre as 10 espécies de camarão mais capturadas em volume no mundo, tendo atingido 41.716 t em 2010 (FAO, 2007, 2012a). 
O Xiphopenaeus kroyeri (Heller, 1862), também conhecido como camarão sete-barbas, é uma espécie da família Penaeidae que se distribui desde o litoral da Carolina do Norte (E.U.A) até Santa Catarina (BR). No Brasil, é desembarcado nos litorais do Paraná, Espírito Santo, Rio de Janeiro, Santa Catarina e São Paulo, tendo alcançado uma produção de mais de 6.000 t, em 2007 (IBAMA, 2011).

No Estado de São Paulo operam, atualmente, seis frotas ou categorias de barcos de pesca classificadas segundo o equipamento de pesca utilizado, entre elas, os arrasteiros-de-portas são os responsáveis pela pesca do camarão. As principais espécies de camarão desembarcadas para o comércio local são o carmarão-setebarbas (X.kroyeri), o camarão-rosa (Farfantepenaeus paulensis, F. brasiliensis e F. subtilis) e o camarão legítimo (Litopenaeus schmitti). Sendo, o camarão sete-barbas, a segunda principal espécie de pescado desembarcada no Estado de São Paulo em 2011, com uma produção de 2.862,4 t (INSTITUTO DE PESCA, 2011).

Por ser uma espécie costeira, o camarão sete-barbas é acessível à pesca de pequena escala, destacando-se entre as espécies marinhas desembarcadas no Estado de São Paulo pelo volume capturado e pelo número de embarcações envolvidas na atividade (SEVERINO-RODRIGUES et al., 1993; INSTITUTO DE PESCA, 2011), possuindo grande relevância social e econômica (GRAÇA LOPES et al., 2007). Segundo Valentini et al.(1991ab), a pesca de camarões na costa do Estado de São Paulo é importante para a economia pesqueira no litoral Sudeste do Brasil, desde a década de 1960.

2.2 O CAMARÃO Xiphopenaeus kroyeri (Heller, 1862)

O gênero Xiphopenaeus é representado no Brasil por uma única espécie, Xiphopenaeus kroyeri (Figura 1), comercialmente denominada por camarão setebarbas. 
O camarão sete-barbas é uma espécie da família Penaeidae e que apresenta ampla distribuição no Atlântico ocidental, da Carolina do Norte (Estados Unidos) ao Rio Grande do Sul (Brasil), incluindo o Caribe e a América Central. No Brasil tem ocorrência registrada em todos os estados, desde o Amapá até o Rio Grande do Sul, neste último apenas com frequência ocasional. Caracteriza-se pelo pequeno tamanho e apresenta $4^{\circ}$ e $5^{\circ}$ pereiópodos alongados, rostro longo, fino e encurvado para cima e télico fechado (IBAMA, 2011).

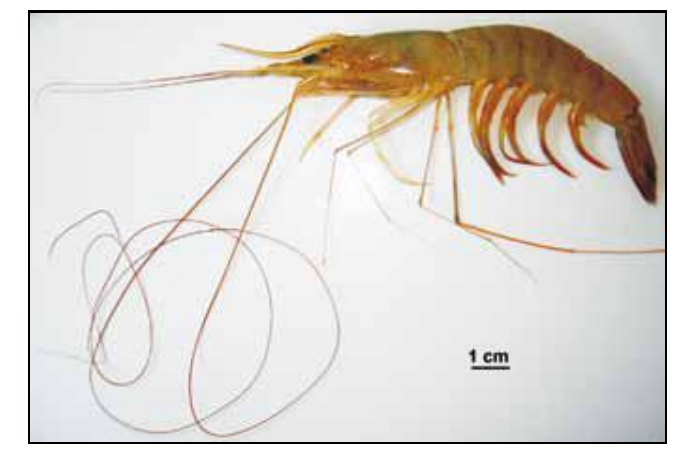

Figura 1. Camarão Xiphopenaeus kroyeri - Extraído de: IBAMA, (2011).

Por não apresentar estratificação populacional bem definida em seu ciclo de vida, a presença de larvas, jovens e adultos de Xiphopenaeus kroyeri é comum na mesma área onde ocorre a pesca da espécie, sendo tradicionalmente capturada com o emprego de arrasto de fundo. Por habitar águas costeiras rasas é principalmente acessível à pesca de pequena escala, embora embarcações consideradas industriais façam parte dessa frota, em especial nos estados de São Paulo e de Santa Catarina (SEVERINO-RODRIGUES et al., 1993).

Os desembarques dessas pescarias ocorrem em muitas comunidades ao longo de todo o litoral da região e são importantes tanto do ponto de vista da segurança alimentar, garantido o alimento na mesa do pescador, como fonte geradora de renda para grande massa de pescadores (IBAMA, 2011). 


\subsection{DIAGNÓSTICO DO MERCADO DE CAMARÕES}

O preço dos produtos pesqueiros seguiu a tendência geral de aumento junto com outros gêneros alimentícios no curso de 2007 e princípio de 2008. Esta foi a primeira vez, em décadas, que o preço do pescado aumentou (FAO, 2008).

$\mathrm{O}$ pescado e seus produtos derivados são altamente comercializados, com mais de $37 \%$ da produção total voltada para o comércio internacional. Embora um enfraquecimento na demanda no final de 2007 e início de 2008, resultante da agitação do setor financeiro e que afetou a confiança do consumidor nos principais mercados, a tendência, em longo prazo, para o comércio de pescado é positiva, com aumento parcial da produção tanto em países desenvolvidos como em desenvolvimento (FAO, 2008).

Segundo o documento The State of World Fisheries and Aquaculture (FAO, 2012b), apesar do ceticismo e preocupação com a situação econômica nos EUA e Europa, as importações de camarão, em 2011, aumentaram em comparação ao ano anterior. No mercado japonês, o camarão cru foi substituído por produtos congelados a base de camarão cozido, com valor agregado, assim pagou-se mais pelas importações. Os mercados nacionais e regionais na Ásia e América Latina também consumiram mais camarão, por isso os preços mantiveram-se relativamente elevados e estáveis ao longo do referido ano.

Dados da FAO (2012b) demonstram que, em 2010, os camarões representaram $15 \%$ do valor total dos produtos pesqueiros comercializados internacionalmente, classificando-os como o mais importante produto pesqueiro comercializado no mercado internacional.

O camarão é um excelente candidato a fonte de proteína alimentar, dado sua popularidade, valor agregado e elevada demanda nos mercados dos EUA, Japão e Europa. Em muitas regiões do mundo faz parte da dieta alimentar e representa importante fonte de proteína de origem animal (HORTON; WRIGHT; WRIGHT, 2008; FAO, 2012b). 
Atualmente, um número cada vez maior de pessoas prefere o pescado, como uma alternativa saudável à carne e, conforme exposto, grande parte do pescado ainda é proveniente do extrativismo. Assim, a indústria de processamento de pescado marinho no Brasil encontra-se limitada na escolha de suas matérias-primas, ao que está disponível em termos de tamanho, condição e espécies.

Neste contexto, o pescador é a pedra fundamental desta cadeia produtiva, pois não existe procedimento posterior à colheita que reconstitua a qualidade inicial da matéria prima a ser utilizada pelas processadoras. Cabendo às instituições governamentais, indústrias e órgãos de ensino e pesquisa aproximarem a comunidade de pescadores dos avanços científicos e da realidade do comércio globalizado (YOKOYHAMA, 2007).

\subsection{QUALIDADE DOS PRODUTOS PESQUEIROS}

O termo "qualidade" com referência aos produtos alimentares pode ter diversos significados. Pode se referir às características sensoriais de um produto, como aparência, sabor, odor e textura, mas pode indicar também o valor nutricional e dietético, o frescor, higiene, facilidade de utilização pelo consumidor, segurança e disponibilidade (Figura 2). No caso do pescado, o frescor assume particular relevância, pois constitui o primeiro critério para a sua aceitação ou rejeição (NUNES; BATISTA, 2004). 


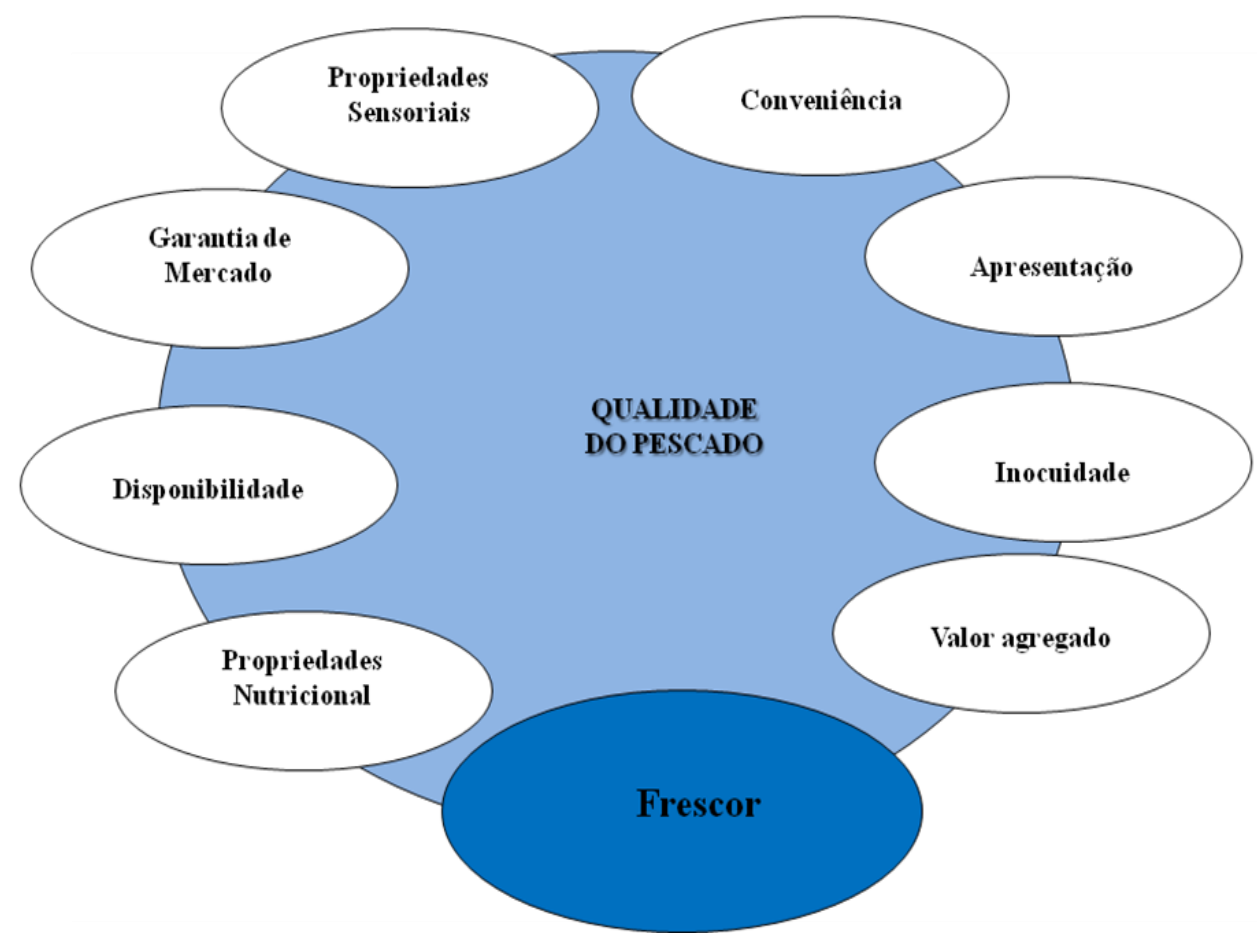

Figura 2. Aspectos da qualidade do pescado. Adaptado de ÓLASFSDÓTTIR et al., (1997).

Os produtos pesqueiros são altamente perecíveis e a manutenção da cadeia do frio, com flutuações mínimas na temperatura, é fundamental para a obtenção de um produto de alta qualidade, principalmente se levarmos em conta a distância transcorrida pelos produtos alimentícios num país de grandes extensões como o Brasil.

Os processos de autólise ou de perda da qualidade iniciam-se logo após a morte do pescado. Em muitos destes processos estão envolvidas substâncias que derivam da metabolização do nitrogênio. Dentre estas substâncias há de se salientar o óxido de trimetilamina (OTMA), um agente osmoregulador em peixes (SORENSEN; GLOB, 1987).

O OTMA pode ser transformado em trimetilamina (TMA), por ação bacteriana ou dimetilamina (DMA) e formaldeído (FA), por influência enzimática (HUSS; ABABOUCH; GRAM, 2004).

Grande parte das alterações da qualidade do pescado é consequência da atividade de microrganismos deteriorantes, como a Shewanella putrefaciens, Vibronaceae, Enterobacteriaceae, Photobacterium sp., Halococcus sp. e 
Halobacterium sp. A deterioração do pescado é acelerada quando a carga microbiana supera $10^{7} \mathrm{UFC} / \mathrm{g}$ (HUSS, 1995).

As modificações químicas que acontecem durante a deterioração ocorrem também ao nível da fração lipídica do pescado. Esta fração pode sofrer reações de oxidação e hidrólise, as quais resultam na produção de substâncias responsáveis pela rancidez e por sabores desagradáveis (HUSS; ABABOUCH; GRAM, 2004).

No caso do camarão marinho, o conceito de qualidade envolve atributos físicos, químicos, biológicos, sensoriais, e ainda as técnicas de captura, processamento, apresentação do produto, armazenamento, distribuição, rastreabilidade e rotulagem, atenção da empresa com os aspectos ambientais e contribuição para o bem estar social. O consumidor moderno está mais exigente quanto ao cumprimento dos requisitos de qualidade por parte das empresas produtoras nos aspectos de segurança do alimento, padronização e fraude econômica, além de responsabilidade ambiental e social.

Os produtos pesqueiros em geral devem concordar com os padrões de qualidade e segurança estabelecidos para plantas de processamento, bem como estar de acordo com a legislação para o tipo de produto. No Brasil, os padrões de qualidade do pescado e derivados estão baseados nos limites estaelecidos para compostos como BNVT e TMA, bem como, na mensuração do pH (BRASIL, 1952). Para a determinação das BNVT, emprega-se um método relativamente simples e consequentemente, muito utilizado para avaliar quimicamente a deterioração do pescado.

Atualmente, com a abertura dos mercados internacionais, processadores devem não somente atender as expectativas nacionais quanto a qualidade, mas também adquirir competitividade no mercado internacional; a análise sensorial é um dos métodos mais utilizados pelos serviços de inspeção do pescado para garantir o frescor e a qualidade no setor pesqueiro.

De acordo com Martinsdóttir (2002), os consumidores, cada vez mais exigentes quanto à qualidade dos alimentos, escolhem o pescado especialmente pela sua aparência a fresco. Portanto, a aceitação do pescado pelo consumidor também é determinada pela qualidade sensorial do produto ofertado. Sendo assim, faz-se extremamente útil o desenvolvimento de métodos que descrevam as propriedades 
sensoriais do alimento, caracterizando os atributos iniciais e as principais mudanças que ocorrem ao longo do seu armazenamento (HUIDOBRO; PASTOR; TEJADA, 2000).

Segundo Bonilla (2004), o QIM poderá se tornar um método sensorial de referência na avaliação de qualidade de pescado fresco dentro da Europa.

2.4.1 Padrões brasileiros para aferição da qualidade de camarões

Grande parte das alterações na qualidade do pescado é consequência da atividade de microrganismos deteriorantes. No entanto, a contagem do número de células viáveis é complexa e consome tempo, não sendo um método prático para definir o frescor. Alguns países, como os Estados Unidos, praticam o monitoramento microbiano das águas de cultivo.

No Brasil não existe ainda um programa de monitoramento efetivo das águas nas áreas de criação e/ou pesca; o Conselho Nacional do Meio Ambiente (CONAMA), por meio da resolução 357, considera que as águas para a criação natural e/ ou intensiva de espécies destinadas à alimentação humana não devem exceder um limite de 1.000 coliformes termotolerantes por $100 \mathrm{~mL}$, em $80 \%$ ou mais de pelo menos 6 amostras coletadas durante o período de um ano, com periodicidade bimestral. (BRASIL, 2005).

Os coliformes termotolerantes são indicadores específicos e apresentam uma elevada correlação positiva com a contaminação fecal por animais de sangue quente. A enumeração de coliformes totais em água é menos representativa como indicação de contaminação fecal que a enumeração de coliformes termotolerantes ou Escherichia coli. No entanto, sua enumeração é muito utilizada em indústrias alimentícias indicando poluição pré-sanitização, contaminação pós-sanitização ou pós-processo (PADUA, 2003).

No Brasil, a Agência Nacional da Vigilância Sanitária (ANVISA), órgão que regulamenta os padrões microbiológicos em alimentos, por meio da resolução RDC 
$\mathrm{n}^{\circ} 12$, preconiza que o camarão in natura, resfriado ou congelado e que não será consumido cru, apresente-se livre de Salmonella sp. em $25 \mathrm{~g}$ e limita em $10^{3}$ a contagem de Staphylococcus coagulase positiva. ${ }^{-1}$ do pescado (BRASIL, 2001).

O Ministério da Saúde, na da Portaria n. 685, de 27 de agosto de 1998, estabelece os limites máximos de tolerância para contaminantes inorgânicos em produtos da pesca, a saber: arsênio $1 \mathrm{mg}$. $\mathrm{Kg}^{-1}$; chumbo $2 \mathrm{mg}$. $\mathrm{Kg}^{-1}$; cádmio $1 \mathrm{mg}$. $\mathrm{Kg}^{-}$ ${ }^{1}$ e mercúrio 0,5 mg. $\mathrm{Kg}^{-1}$ (BRASIL, 1998).

Segundo o Regulamento de Inspeção Industrial e Sanitária dos Produtos de Origem Animal (RIISPOA) (BRASIL, 1952), os crustáceos devem apresentar aspecto brilhante, úmido; corpo em curvatura natural, rígido e com artículos firmes e resistentes; carapaça bem aderente ao corpo; coloração própria da espécie, sem qualquer pigmentação estranha; olhos vivos, destacados; cheiro próprio e suave.

Os padrões analíticos da qualidade do camarão também estão baseados na análise de compostos como BNVT, TMA e ainda, na mensuração do pH e do teor de indol (BRASIL,1952). Para Botta (1995), estes parâmetros não são capazes de identificar estágios iniciais da perda do frescor; indicando apenas se o produto encontra-se em estágios avançados de deterioração. O mesmo autor alerta que estudos visando o estabelecimento de limites críticos mais adequados são necessários, com monitoramento das amostras imediato após a captura e ao longo da sua vida útil, sob condições ideais de armazenamento.

Sendo uma prática comum o uso de sulfitos em crustáceos, a legislação brasileira, por meio da Resolução CNS/MS N. 04, de 24 de novembro de 1988, aprova o uso do metabissulfito de sódio, metabissulfito de potássio, metabissulfito de cálcio, sulfito de sódio, sulfito de cálcio, sulfito de potássio, bissulfito de cálcio, bissulfito de sódio e bissulfito de potássio em camarões e lagostas (exclusivamente na matéria-prima após a captura); limitando o teor residual de dióxido de enxofre a $100 \mathrm{mg}$. $\mathrm{Kg}^{-1}$ de camarão cru, e a $30 \mathrm{mg}$. $\mathrm{Kg}^{-1}$ no produto cozido (BRASIL, 1988). 
2.4.2 Aspecto sensorial do pescado: método do índice de qualidade

A análise sensorial tem tido papel fundamental como um dos métodos mais utilizados para garantir o frescor e a qualidade do pescado pelos serviços de inspeção (ABBAS et al., 2008). No entanto, é uma metodologia subjetiva, que apesar das vantagens como baixo custo, rapidez e apresentar relação direta com os padrões de aceitação do consumidor; exige a participação de um número representativo de julgadores treinados para obtenção de resultados confiáveis e reprodutíveis, o que na prática, muitas vezes, não é viável.

Neste contexto, alternativamente, em tempos recentes, alguns autores vêm estabelecendo o Método do Índice de Qualidade, ou “QIM” para diferentes espécies de pescado de importância comercial, a saber: Merluccius merluccius, Rachycentron canadum, Sparus aurata, L., Pagellus bogaraveo, Trachurus trachurus, Dicentrarchus labrax, Sepia officinalis, L., Salvelinus alpinus, Gadus morhua, Solea senegalensis, Chelidonichthys lucernus, Hippoglossus hippoglossus, Engraulis encrasicholus, entre outras. No entanto, nenhum estudo foi realizado com o camarão Xiphopeneaus kroyeri.

O QIM foi desenvolvido, durante a década de 1980, na Tasmanian Food Research Unit (BREMNER, 1985) e baseia-se na avaliação dos atributos sensoriais considerados significativos (aparência, textura, odor, entre outros.) através de um sistema de classificação por pontos de demérito (de 0 a 3), onde a soma dessas classificações quantifica a falta de qualidade sensorial até um valor máximo, específico de cada espécie/gênero, que corresponde à ausência total de qualidade (impróprio para consumo humano) e que se obtém a partir da análise sensorial do pescado por um painel restrito de julgadores treinados (HUSS, 1995).

Segundo Martinsdóttir et al. (2003), trata-se de um método rápido e que tem sido indicado como referência na padronização e harmonização da avaliação sensorial do pescado na Europa. Os autores sugerem uma relação linear entre o QIM e o tempo de estocagem em gelo para diversas espécies de pescado, sendo uma ferramenta prática, objetiva e útil para a indústria da pesca. 
Esteves e Aníbal (2007) também indicaram o QIM como ferramenta para o estabelecimento da vida útil do pescado, uma vez que os resultados obtidos estão linearmente relacionados com o tempo de conservação.

Os consumidores, cada vez mais exigentes quanto à qualidade dos alimentos, também determinam a aceitação ou rejeição sensorial do pescado e produtos derivados (MARTINSDÓTTIR et al., 2001). Por esta razão faz-se extremamente útil o desenvolvimento de métodos que descrevam as propriedades sensoriais do alimento, caracterizando os atributos iniciais e as principais alterações que possam ocorrer ao longo da estocagem (HUIDOBRO; PASTOR; TEJADA, 2000).

Segundo Hyldig e Nielsen (2004) e Nunes e Batista (2004), as vantagens do QIM são requerer treinamento simples, ser rápido, não-destrutivo e objetivo. Nenhum atributo tem peso excessivo na classificação final do pescado e quanto maiores forem as alterações em determinada característica, derivadas da deterioração, maior será a classificação atribuída. Podendo ser útil como ferramenta no planejamento, na produção e na garantia da qualidade.

\subsubsection{Aspecto microbiológico}

Uma série de testes microbiológicos são utilizados pelas indústrias e agências sanitárias na averiguação da condição microbiológica do pescado e produtos derivados. O objetivo destas análises é detectar a presença de bactérias patogênicas (Salmonella spp., Vibrio parahaemolyticus, Staphylococcus aureus, Listeria monocytogenes, Escherichia coli) e/ou de microrganismos indicadores de contaminação fecal (E. coli) ou outros tipos de contaminação, como as resultantes de práticas inadequadas de manipulação (coliformes totais, Streptococcus spp, $S$. aureus), da contaminação ambiental (Clostridium botulinum), entre outros.

Embora o controle microbiológico seja parte essencial em qualquer programa de controle e gestão da qualidade de alimentos, há certas limitações e deficiências. A alta rotatividade de pessoal nos sistemas de fiscalização e nas áreas de 
processamento obriga que o processo de capacitação seja um exercício contínuo. Os ensaios microbiológicos também tem algumas limitações, como a morosidade, não se obtendo os resultados em tempo viável à comercialização do pescado e, ainda, há dificuldades relacionadas a amostragem, aos métodos de análise e a utilização de organismos indicadores (HUSS, 1993).

Grande parte das alterações na qualidade do pescado é consequência da atividade de microrganismos deteriorantes. Segundo Lyhs (2009), algumas das principais bactérias deteriorantes em produtos pesqueiros são as Pseudomonas spp., bactérias produtoras de $\mathrm{H}_{2} \mathrm{~S}$, Shewanella spp., Enterobacteriaceae, bactérias ácido láticas, Photobacterium phosphoreum, Brochothrix thermospacta, entre outras.

Alguns peixes de água doce e muitas espécies de águas tropicais, durante o armazenamento em gelo e em condições aeróbias, têm como característica o desenvolvimento de odor frutado, sulfídrico e enjoativo, típico da deterioração causada por Pseudomonas (HUSS, 1995). Vieira (2011) afirma que a presença de Pseudomonas é mais pronunciada no pescado marinho, independente das condições de temperatura da água e que, a presença de Enterobacteriaceaes, principalmente os coliformes, é mais frequente no pescado fluvial.

Chinivasagam et al., (1998) estudaram o desenvolvimento de bactérias produtoras de $\mathrm{H}_{2} \mathrm{~S}$ em camarões (Penaeus plebejus, Metapenaeus bennettae e P. esculentos/ semiculcatus) armazenados em gelo e em gelo líquido, encontrando que, as bactérias produtoras de $\mathrm{H}_{2} \mathrm{~S}$ eram $10 \%$ ou menos do total das bactérias, durante o armazenamento em gelo, enquanto no armazenamento em gelo líquido, o desenvolvimento das mesmas foi crescente ao longo do período de estocagem.

Huss (1993) ressalta que a refrigeração adequada dos produtos pesqueiros é essencial para controle do crescimento de microrganismos, inclusive de víbrios patogênicos.

A excelência nutricional do pescado como fonte de proteína, o seu elevado teor de umidade, a elevada digestibilidade de suas fibras musculares e o seu pH próximo da neutralidade, propiciam o crescimento microbiano e, por sua vez, determinam a sua reduzida vida útil. Portanto, com vistas a garantir a segurança alimentar na cadeia produtiva do pescado é imprescindível a manutenção da alta 
qualidade em cada elo da cadeia produtiva, como prevê a ABNT NBR ISO 22000 Sistemas de gestão da segurança de alimentos.

No caso do pescado, os cuidados com a qualidade iniciam-se na água. Assim, programas de monitoramento das águas de cultivo ou de captura, do pescado continental, são estratégias importantes no controle sanitário do pescado. Somandose aos programas de monitoramento, a capacitação contínua dos profissionais da pesca e manipuladores de pescado em BPM, bem como, a implantação de sistemas de qualidade nas indústrias, avançar-se-á na oferta de produtos de pescado de maior valor agregado.

Neste sentido a ABNT NBR ISO 22000 é uma ferramenta importante, pois é aplicável à todas as organizações da cadeia produtiva de alimentos, envolvendo todas as pessoas e todas as etapas da cadeia produtiva.

\subsubsection{Aspecto físico}

A redução do pH muscular do pescado, após a morte, exerce efeito sobre as suas propriedades físicas. À medida que o $\mathrm{pH}$ decresce, ocorre uma desnaturação parcial das proteínas e estas perdem a capacidade de retenção da água, afetando a textura do músculo (HAARD, 1992; HUSS, 1995). Apesar do pH isoladamente, não ser considerado um bom parâmetro da qualidade, o conhecimento do valor de $\mathrm{pH}$ do músculo do pescado pode fornecer informação importante sobre a sua condição.

Com a morte do pescado, uma vez suprimida a chegada de oxigênio ao músculo, a glicólise ocorre em condições de anaerobiose, resultando na formação de ácido lático e consequente redução no $\mathrm{pH}$ muscular. O músculo do pescado, geralmente, contém níveis de glicogênio inferiores aos mamíferos, conferindo um $\mathrm{pH}$ final mais elevado. Ao longo da degradação do pescado o decréscimo do $\mathrm{pH}$ varia de 7,0 para 6,2 - 6,5, enquanto em outras carnes este abaixamento é maior, para cerca de 5,5 (OGAWA; MAIA, 1999; VAZ-PIRES, 2006). 
Há variação do teor de glicogênio entre as diferentes espécies de pescado, bem como, entre as diferentes partes do corpo dos peixes. Em peixes e crustáceos, o glicogênio é decomposto a ácido lático, enquanto nos moluscos, além do ácido lático há formação da octopina (OGAWA; MAIA, 1999).

As condições de morte do pescado também influenciam no seu conteúdo de glicogênio. O pescado abatido ou que morre após atividade muscular intensa apresenta teores reduzidos de glicogênio, suas células contêm mais ácido lático e o rigor mortis se instala precocemente. Segundo Vaz-Pires (2006), quanto menores o estresse e a temperatura de conservação do pescado, mais tardio o início do rigor mortis e mais extenso o seu período de conservação útil.

As alterações bioquímicas, como o aumento do BNVT devido à degradação por microrganismos e ação de enzimas tissulares, promovem a elevação do $\mathrm{pH}$ muscular. Gonçalves e Junior (2009) obtiveram pH 9,10 e 9,27 para o camarão setebarbas, no tempo zero do armazenamento sob congelamento. Estes mesmos autores demonstraram a redução do $\mathrm{pH}$ muscular durante o armazenamento sob congelamento do produto glaciado.

Mendes et al., (2005) verificaram que amostras de camarão Parapenaeus longirostris de qualidade aceitável apresentavam $\mathrm{pH} \leq 7,9$.

De acordo com o RIISPOA, o pescado é considerado adequado para o consumo quando o $\mathrm{pH}$ da carne externa é inferior a 6,8 e o da carne interna inferior a 6,5 (BRASIL, 1952).

É largamente divulgado que, em pescado de alta qualidade, os tecidos retornam à sua forma original após serem pressionados levemente. Uma textura mole ou uma sensação viscosa são indicadores de deterioração avançada. No entanto, são escassos os estudos que analisam a relação entre propriedades de textura e a qualidade do pescado in natura.

Gökodlu, Özden e Erkan (1998) observaram que sardinhas estocadas por 10 dias a $4^{\circ} \mathrm{C}$ apresentaram firmeza reduzida ao longo do período de armazenamento, enquanto o pH se elevava. Pornrat et al., (2007) apontaram que o aumento da temperatura leva ao amolecimento precoce do pescado, uma vez que propicia o desenvolvimento microbiano. 
A velocidade de decomposição do pescado depende do número e da espécie das bactérias infectantes, uma vez que há grande variação no comportamento destas quanto à capacidade de causar deterioração. Assim, os cuidados com o binômio tempo $\mathrm{X}$ temperatura, acrescido da higiene, são determinantes na qualidade do pescado.

2.4.5 Aspecto químico

Os produtos pesqueiros apresentam uma composição em aminoácidos essenciais balanceada. Sendo, a sua proteína muito sensível as ações deteriorantes, devido a presença de enzimas que as hidrolisam. No entanto, sob condições apropriadas de manipulação e conservação, a perda da qualidade devido a hidrólise, polimerização, desaminação, descarboxilação, oxidação, dentre outras alterações, podem ser prevenidas ou minimizadas (SHAHIDI, 2004).

As alterações post-mortem ou degradação é um fenômeno complexo e iniciase com a morte do pescado, embora alguns acontecimentos que a antecedem influenciem todo o processo. Os primeiros acontecimentos após a morte do pescado estão relacionados a adenosina-trifosfato (ATP) e produtos da sua decomposição (VAZ-PIRES, 2006). Por isso, em linhas gerais, as únicas determinações químicas relacionadas a determinação do frescor em pescado são as que quantificam os nucleotídeos e os produtos da sua decomposição, como a hipoxantina, inosina ou ainda, o valor $\mathrm{K}$.

Saito, Arai e Matsuyoshi (1959) foram os primeiros a observar essas alterações autolíticas e a desenvolver uma fórmula para determinar o frescor do pescado:

$$
\mathrm{K}(\%)=\frac{[\text { Inosina }]+\lceil\text { Hipoxantina }]}{[\mathrm{ATP}]+[\mathrm{ADP}]+[\mathrm{AMP}]+[\mathrm{IMP}]+[\mathrm{Ino}]+[\mathrm{Hx}]} \mathrm{X} 100
$$


Onde [ATP], [ADP], [AMP], [IMP], [Ino] e [Hx] representam as concentrações relativas destes compostos, mensuradas no músculo do pescado durante o período de armazenamento sob refrigeração, a saber: Adenosina Trifosfato, Adenosina Difosfato, Adenosina Monofosfato, Inosina Monofosfato, Inosina e Hipoxantina, respectivamente.

Com alguns parâmetros químicos já estabelecidos pode-se estabelecer uma escala de frescor para o pescado, entre eles, a determinação do BNVT, a quantificação das aminas biogênicas, bem como, de peróxidos e do indol. No entanto, muitos destes compostos são formados quando o pescado já apresenta uma deterioração avançada e já não pode ser consumido.

No Brasil, os padrões químicos da qualidade do pescado e derivados são prerrogativas do RIISPOA e estão baseados na análise de compostos como BNVT e TMA, bem como, do teor de indol e na reação negativa de gás sulfídrico (BRASIL, 1952). Para a determinação das BNVT, emprega-se um método relativamente simples e, consequentemente, largamente utilizado para avaliar quimicamente se o pescado encontra-se com qualidade para o consumo.

Já a determinação do teor do indol caiu em desuso pelos laboratórios de cunho fiscal no país, Laboratórios Nacionais Agropecuários (LANAGRO). Leitão e Rios (2000) e Mendes et al., (2005), verificaram a rejeição sensorial de camarões antes mesmo da detecção do indol, indicando a ineficácia da utilização deste índice de forma isolada.

A putrescina e cadaverina são aminas biogênicas mensuráveis, principalmente, durante os últimos estágios de armazenamento sob refrigeração, sendo normalmente utilizadas como indicadoras da qualidade e inocuidade do pescado. Segundo Otwell et al., (2001) e Benner et al., (2003), estas aminas podem confirmar mais prematuramente a decomposição sensorial de camarões que o indol.

As aminas biogênicas são formadas como resultado da descarboxilação dos aminoácidos livres pelos microrganismos presentes no pescado, merecendo especial atenção devido ao seu potencial tóxico. Entretanto, os níveis de toxicidade das aminas são difíceis de estabelecer, uma vez que dependem de fatores do indivíduo e da presença de outras aminas. 
A histamina, devido a sua elevada toxicidade, apresenta limite estabelecido de até $100 \mathrm{mg} . \mathrm{Kg}^{-1}$ de alimento (BRASIL, 1997). Nos EUA, o FDA estabelece limites para peixes susceptíveis à formação de histamina, como os das famílias Scombridae e Scomberesocidae, de $50 \mathrm{mg}$. $\mathrm{Kg}^{-1}$ (EUA, 2011).

Segundo Önal (2007), a putrescina, a cadaverina, a espermina e a espermidina não apresentam efeitos adversos significativos comprovados, mas estas, além de potenciarem os efeitos da histamina, podem reagir com nitritos e formar nitrosaminas carcinogênicas.

De acordo com o Departamento de Saúde e Serviços Humanos dos EUA (EUA, 2011), também os produtos químicos formados a partir da oxidação das gorduras dos alimentos podem causar, em longo prazo, efeitos deletérios à saúde.

Para Fogaça e Sant'Ana, (2009), devido ao alto grau de insaturação dos ácidos graxos presentes no pescado, a oxidação lipídica é uma das principais causas da sua deterioração.

Muitos métodos têm sido propostos para quantificar os compostos resultantes da oxidação lipídica, a saber, a determinação do índice de peróxido, TBARS, teste de Kreis, entre outros. Em tecidos animais, a determinação de TBARS tem sido o método mais utilizado na avaliação da oxidação lipídica, onde o (di)aldeído malônico, principal composto secundário encontrado nos lipídios oxidados, reage com o TBA (VYNCKE, 1970).

Segundo Huss (1995), o pescado gordo é naturalmente mais susceptível à degradação de lípidos, o que pode desencadear graves problemas de qualidade, mesmo em armazenamento a baixas temperaturas.

\subsection{SEGURANÇA ALIMENTAR NA CADEIA PRODUTIVA DO PESCADO}

Muitos consumidores sabem que o pescado e muitos de seus produtos derivados são itens alimentares altamente perecíveis, mas poucos conhecem a 
complexidade desta cadeia produtiva e quão complicada pode ser a trajetória do pescado até o prato do consumidor (SCHRÖDER, 2008).

Informações quanto às técnicas de manipulação, processamento e estocagem, incluindo histórico de tempo e temperatura, que podem afetar o frescor e qualidade dos produtos, são de grande importância para os agentes desta cadeia produtiva. Adicionalmente, as condições ambientais, que afetam as áreas de pesca, os métodos de captura e a ocorrência de defeitos, influenciam diretamente na qualidade geral dos produtos pesqueiros (ABBAS et al., 2008).

Os processos de autólise, que levam a perda da qualidade, iniciam-se logo após a morte do pescado (HUSS, 1995). As aminas biogênicas formadas, como resultado da descarboxilação dos aminoácidos livres, pelos microrganismos presentes no pescado merecem especial atenção, devido ao seu potencial tóxico.

Dentre as aminas biogênicas, a mais comentada é a histamina, responsável pela intoxicação histamínica ou por escombrídeos, assim denominada por estar associada, principalmente, a ingestão de atuns, cavalas, bonitos, entre outras espécies da família Scombridae. Em algumas espécies de pescado, especialmente nos moluscos, a agmatina é a amina de maior importância (LAPA-GUIMARÃES, 2005).

Em lagostas e camarões, como conseqüência do processo deteriorativo, há o aparecimento de manchas pretas (melanose). Substâncias redutoras tais como sulfitos, ácido ascórbico e cisteína, são normalmente utilizadas no controle da melanose (OGAWA; DINIZ, 1999).

Outra fonte importante de contaminação é a manipulação do pescado, desde o momento da captura até a sua destinação final. Como consequiência direta da manipulação inadequada tem-se apontado os Streptococcus spp e o Staphylococcus aureus, ambos de origem humana, presentes nas mucosas e superfície da pele, e que encontram no pescado ambiente favorável à sua multiplicação.

O pescado também pode ser veiculador de uma gama de microrganismos patogênicos para o homem, a maior parte deles oriundos da contaminação ambiental. Neste sentido é importante destacar as bactérias do gênero Samonella e a Shigella spp, encontradas em águas poluídas por esgotos ou excretas animais. No caso particular da pesca marítima, a captura em águas costeiras oferece maiores riscos do que a realizada em alto mar (GERMANO; GERMANO; OLIVEIRA, 2008). 
Ainda relacionado ao ambiente hídrico temos os víbrios, merecendo destaque o vírus da hepatite tipo A (VHA) e o vírus de Norwalk ou norovírus (LIMA DOS SANTOS, 2010)

Poluentes químicos, biotoxinas e endoparasitas são outros riscos associados ao consumo do pescado. Dentre os poluentes químicos o mercúrio e o arsênio assumem grande relevância em saúde pública, devido a elevada toxicidade, persistência, efeito cumulativo para o homem e porque o pescado é considerado a principal fonte de exposição destes contaminantes (BRASIL, 1999).

Também os parasitas zoonóticos são uma crescente preocupação no mercado nacional, frente ao considerável aumento na oferta de produtos de pescado cru do tipo sashimi e sushi. Lima dos Santos (2010), em levantamento recente sobre as doenças transmitidas por pescado no Brasil, aponta como os principais parasitas patogênicos ao homem os helmintos pertencentes as famílias Opisthorchiidae, Heterophyidae, Paragonimidae (trematóides), Anisakidae, Gnathostomidae (nematóides) e Diphyllobothridae (cestóides).

Diante deste cenário, torna-se evidente a importância de os consumidores e demais elementos desta cadeia produtiva se atentarem à origem e qualidade dos produtos de pescado consumidos e comercializados, bem como, a necessidade de se implantar programas de gestão da qualidade, sobretudo de rastreabilidade dos produtos da pesca e aqüicultura.

Atualmente, para se garantir a segurança no consumo do alimento pode-se lançar mãos da ABNT NBR ISO 22000 Sistemas de gestão da segurança de alimentos, que permite às organizações demonstrar sua habilidade em controlar os perigos de contaminação.

\subsection{MELANOSE EM CAMARÕES}

A melanose, também denominada "black spot" caracteriza-se pelo desenvolvimento de manchas pretas em crustáceos, sendo considerada inofensiva, 
visto não causar prejuízos à saúde do consumidor. Entretanto, é a causa mais comum da rejeição de lagostas e camarões, ou seja, o principal entrave na comercialização destes crustáceos.

O escurecimento ocorre, principalmente, ao longo das pleópodes, cefalotórax, cauda e nas adjacencias da carapaça, antes de se espalhar ao longo do corpo. Os fatores que induzem à melanose ainda não estão bem esclarecidos, é evidenciado que a formação de melanina compreende uma reação enzimática oxidativa, seguida de reações de autoxidação e polimerização (OGAWA; DINIZ, 1999).

Substâncias redutoras tais como sulfitos, ácido ascórbico e cisteína são usualmente empregadas no controle da melanose, devido a propriedade de reduzirem imediatamente $\alpha$-quinona, retardando a formação da melanina (OGAWA; DINIZ, 1999).

No entanto, o uso de aditivos químicos em camarões, com o intuito de prevenir a melanose, vem sofrendo restrições, principalmente pelo mercado externo, devido aos excessos aplicados e efeitos tóxicos por eles provocados (MORAIS, 1984, WHO, 2009).

O emprego de metabissulfito de sódio para inibição da melanose em camarões de extrativismo, bem como, daqueles provenientes da carcinicultura tem sido alvo de críticas, pelo uso inapropriado ou falta de conhecimento em relação ao uso adequado deste produto químico. Os sulfitos são empregados ainda a bordo das embarcações e quando usados em excesso podem não só causar reações adversas em indivíduos sensíveis ao dióxido de enxofre, mas também favorecer a decomposição do óxido de trimetilamina (OTMA) à dimetilamina (DMA) e a formaldeído (FA), comprometendo a qualidade do produto e do meio ambiente quando seus resíduos são descartados sem tratamento adequado.

No Brasil, o uso do metabissulfito de sódio é comum entre pescadores, carcinicultores e processadores de camarão, visando impedir o aparecimento da melanose. A utilização deste produto químico está amparada na legislação brasileira pela resolução 14/77 da Comissão Nacional de Normas e Padrões para Alimentos (CNNPA) que diz "Estender o emprego de bissulfito de sódio em solução para imersão ou no gelo, a 1,25\% como conservador para camarões e lagostas crus, não 
devendo o dióxido de enxofre $\left(\mathrm{SO}_{2}\right)$ residual ultrapassar $100 \mathrm{mg} \cdot \mathrm{Kg}^{-1}$, pressuposto o emprego de adequada tecnologia de processamento" (BRASIL, 1988).

O FDA recomenda níveis menores que $100 \mathrm{mg} \cdot \mathrm{Kg}^{-1}$ de $\mathrm{SO}_{2}$ na porção comestível de camarões e que seja adotado o método de Monier-Williams modificado na determinação (COOPER et al., 1986, HILLERY et al. 1989).

Segundo Ogawa e Maia (1999), na região Norte do país procede-se a imersão dos camarões em solução a $2 \%$ de metabissulfito de sódio, em temperatura em torno de $-10^{\circ} \mathrm{C}$, durante $10 \mathrm{~min}$. Esses autores, afirmam que o emprego de concentrações usuais do bissulfito de sódio dificilmente inibirá a formação de tais manchas se os espécimes sofreram traumas previamente, o que é de se esperar numa operação de pesca, e que com a utilização da referida concentração o teor residual de $\mathrm{SO}_{2}$ no produto seria maior que o recomendado. A necessidade de altas concentrações de aditivos para prevenção da melanose em camarões também fora apontada por Montero, Lopez-Caballero e Perez-Mateos (2001).

Diante do exposto se vislumbra a necessidade de implantação das Boas Práticas de Manipulação (BPM) nas embarcações pesqueiras, visando minimizar os impactos negativos sobre a qualidade da matéria-prima, com consequente redução no aporte de preservativos e dos riscos à saúde.

O uso excessivo de sulfitos e a deficiente qualidade do pescado desembarcado no Brasil vêm sendo apontados em alguns estudos (THAMPURAN; GOPAKUMAR, 1990; MOURA et al., 2003; OGAWA et al., 2003; YOKOYAMA, 2007; FURLAN; TORRES, 2010; MACHADO et al., 2010; FURLAN et al., 2012).

Os sulfitos ingeridos são oxidados a sulfatos e tiossulfatos, por ação enzimática, sendo excretados pela urina, não causando risco em níveis normais de uso para a maioria da população (MACHADO; TOLEDO; VICENTE, 2006).

Porém, alguns estudos indicam casos de sensibilidade à ingestão de sulfitos. O FDA através do Center for Food Safety and Applied Nutrition (CFSAN) tem monitorado casos de reações adversas ligadas à ingestão de alimentos com sulfitos desde 1980. Do total de 799 casos analisados, até o ano 2000, 48,6\% foram classificados como severos; estudos posteriores sugeriram os sulfitos, na forma de dióxido de enxofre, como agente causal das enfermidades (EUA, 2000). 
No Brasil, nas últimas décadas, o índice de camarões danificados pela melanose, vem decrescendo. Esta redução na rejeição pode estar associada ao emprego abusivo de sulfitos, o que pode estar comprometendo o consumo do camarão no mercado interno pelo desenvolvimento de alergias. Aliando esta problemática a deficiente fiscalização dos produtos pesqueiros destinados ao mercado interno, vê-se a necessidade de desenvolvimento de ferramentas que contribuam para redução dos riscos associados ao consumo de camarões.

Morais (1995) pesquisou o uso do metabissulfito associado ao ácido cítrico e afirmou ser viável tecnicamente a utilização do sistema ácido-conservante na redução dos casos de melanose em camarões sete-barbas inteiros e descabeçados, reduzindo os teores residuais de $\mathrm{SO}_{2}$ no produto. No entanto, este mesmo autor sugere a necessidade de se investigar combinações de ácido cítrico com substâncias que possuam propriedades conservantes mais estáveis que o metabissulfito de sódio.

Montero, Martínez-Álvarez e Gómez-Guillén (2004) verificaram a eficiência da utilização do 4-hexylresorcinol na inibição da melanose em camarões (Parapenaeus longirostris), ainda a bordo da embarcação, e seu uso em combinação com ácido cítrico, ascórbico e ácido acético e sugeriram que as combinações não alteram a vida útil do camarão quando comparado ao uso do 4-hexylresorcinol isoladamente, mas a presença dos ácidos conferiu uma melhor aparência.

\subsection{VIDA ÚTIL DOS CAMARÕES}

Entende-se por vida útil de um produto pesqueiro, o período compreendido desde a sua morte ou abate até a sua rejeição por determinado fator (BARBOSA; BREMNER; VAZ-PIRES, 2002), como por exemplo, a inadequação para o consumo.

Para Martinsdóttir et al., (2001), o período de vida útil do pescado é o tempo em que ele se encontra apto para o consumo. Sendo a degradação devida à atividade microbiana, o maior limitante deste período de conservação útil. 
Outra importante causa da degradação é a rancidez, especialmente em espécies de peixes gordos.

A vida útil para as diversas espécies de pescado é estimada, nas investigações científicas, assumindo condições ótimas de armazenamento e, normalmente, utilizando-se de métodos sensoriais combinados aos métodos físico, químicos e/ou microbiológicos.

Os métodos sensoriais são normalmente baseados em tabelas sensoriais. O método sensorial mais difundido na Europa é a tabela Torry, utilizada oficialmente e, mais recentemente, o QIM, que vem sendo desenvolvido para as espécies de pescado de importância comercial.

Quando se usa a tabela Torry, o período de vida útil é determinado pela rejeição do pescado inteiro, com base em aspectos visíveis externamente e ensaios não-destrutivos, recorrendo a avaliação das características internas, apenas quando o peixe apresenta-se eviscerado.

A rejeição pelo QIM pode ser estimada comparando-se o índice de qualidade com os resultados obtidos na avaliação sensorial do produto cozido por um painel de julgadores.

$\mathrm{Na}$ avaliação sensorial do pescado cozido recorre-se frequentemente às tabelas descritivas Torry, principalmente, para avaliação do odor e sabor (HOWGATE, 1982; MARTINSDÓTTIR et al., 2009). Em geral, a pontuação varia entre 10 e 3 pontos, correspondendo ao pescado muito fresco e deteriorado, respectivamente. Esta classificação tem sido usada para determinar a rejeição sensorial de pescado e como critério para definição do período de vida útil.

Independentemente de tabelas ou sistemas, os métodos sensoriais são os mais apropriados para se estimar a vida útil do pescado, pois representam a opinião do consumidor, além de serem mais rápidos e simples, requisito essencial na avaliação de produtos altamente perecíveis, como no caso do pescado (BARBOSA; BREMNER; VAZ-PIRES, 2002).

$\mathrm{O}$ pescado, de maneira geral, apresenta uma vida comercial restrita. $\mathrm{O}$ período de vida útil depende, principalmente, da temperatura de conservação e da espécie em questão (HUSS, 1995; GRAM; HUSS, 1996). 
Os crustáceos apresentam uma vida útil ainda mais restrita, visto apresentarem uma rejeição precoce devido ao desenvolvimento da melanose. Entretanto, são escassos os estudos que determinam a vida útil dos camarões.

Kirschnik e Viegas (2004) encontraram que o camarão Macrobrachium rosenbergii manteve-se apto ao consumo até o $4^{\circ}$ dia de armazenamento em gelo, em contato direto ou embalado em saco de polietileno. Enquanto, Leitão e Rios (2000) indicaram 10 dias de vida útil a $0^{\circ} \mathrm{C}$ para a mesma espécie, com redução da sua vida útil para 5 dias, quando armazenados em temperatura de $5^{\circ} \mathrm{C}$.

Garrido et al. (2012) estimaram uma vida útil de 14 dias para camarões Litopenaeus vannamei, adequadamente manipulados e tratados com Everfresh (4hexylresorcinol) e apontam que o uso de conservantes é essencial para manutenção da qualidade em camarões.

Para o camarão X.kroyeri nenhum estudo sobre o QIM foi realizado. No entanto, este método pode ser útil para dar gabarito aos pescadores deste crustáceo a respeito da qualidade da sua captura, o que poderá influenciar positivamente na manipulação a bordo das embarcações pesqueiras (CARDENAS BONILLA; SVEINSDOTTIR; MARTINSDOTTIR, 2007) e prolongar a sua vida útil.

\subsection{MANUSCRITOS}

Esta revisão bibliográfica resultou em 2 manuscritos, a saber: (1) FURLAN, É.F. Valoração da qualidade do camarão sete-barbas (Xiphopenaeus kroyeri) desembarcado no litoral de São Paulo, Brasil. Boletim do Instituto de Pesca, v. 37, n.3, p. 317-326, 2011 (Anexo 1); (2) FURLAN, É.F. Qualidade das matérias-primas de origem animal: pescado. In: GERMANO, P.M.L.; GERMANO, M.I.S. (Ed.) Sistema de gestão: qualidade e segurança dos alimentos. São Paulo: Manole, 2012. 578p (Anexo 2). 


\section{OBJETIVOS}

\subsection{GERAL}

Desenvolver um protocolo de qualidade sensorial para o camarão marinho Xiphopenaeus kroyeri, a partir do Método do Índice de Qualidade ou QIM e avaliar o protocolo em um estudo de vida útil em gelo.

\subsection{ESPECÍFICOS}

- Caracterizar a qualidade do camarão marinho Xiphopenaeus kroyeri desembarcado na Baixada Santista, SP, Brasil;

- Selecionar os parâmetros mais adequados como indicadores de qualidade para o camarão marinho Xiphopenaeus kroyeri;

- Estabelecer a vida útil do camarão marinho Xiphopenaeus kroyeri estocado em gelo com e sem o uso de metabissulfito;

- Desenvolver e otimizar um esquema de avaliação sensorial que permita discriminar o grau de frescor e prever o período de vida útil do camarão marinho Xiphopenaeus kroyeri armazenado em gelo, com e sem o uso de sulfito. 


\section{REFERÊNCIAS}

1. ABBAS, K.A.; MOHAMED, A.; JAMILAH, B.; EBRAHIMIAN, M. A review on correlations between fish freshness an $\mathrm{pH}$ during cold storage. American journal of biochemistry and biotechnology, v.4, n.4, p.416-421, 2008.

2. ANSORENA, D.; DE PEÑA, M.P.; ASTIASARÁN, I.; BELLO, J. Colour evaluation of chorizo de Pamplona, a Spanish dry fermented sausage. Comparison between the CIEL*a*b* and Hunter lab systems with illuminats D65 and C. Meat Science, v.46, n.4, p. 313-318, 1997.

3. BARBOSA, A.; BREMNER, A.; VAZ-PIRES, P. The meaning of shelf-life. In: BREMNER, H.A. (Ed.) Safety and quality issues in fish processing. Cap.11. Cambridge: Woodhead Publishing, 2002. 520p.

4. BONILLA, A.C. Development of a quality index method (QIM) scheme for fresh cod (Gadus morhua) fillets and consumer acceptance of different cod products. The United Nation University - UNU. Fisheries Training Programme. Final Project 2004. 54p.

5. BOTTA, J.R. Evaluation of seafood freshness quality. New York: VCH Publisher, 1995. 180p.

6. BRASIL. Ministério da Agricultura. Regulamento de Inspeção Industrial e Sanitária de Produtos de Origem Animal (R.I.I.S.P.O.A): Decreto n ${ }^{\circ} 30.691$ de 29 de março de 1952. Seção 1, Capítulo 7 - Pescados e Derivados. Diário Oficial da União, Brasília, DF. 07 de julho de1952. p.71-73.

7. BRASIL. Ministério da Saúde. Resolução CNS/MS n ${ }^{\circ} 04$, de 24 de novembro de 1988, do Conselho Nacional da Saúde. Diário Oficial da União, Brasília, DF. 19 de dezembro de 1988. Seção 1. 
8. BRASIL. Ministério da Agricultura, Pecuária e do Abastecimento. Regulamento técnico de identidade e qualidade de peixe fresco (inteiro e eviscerado). Portaria ${ }^{\circ}$ 185, de 13 de maio de 1997. Brasília, DF. 1997.

9. BRASIL. Ministério da Saúde. Princípios Gerais para o Estabelecimento de Níveis Máximos de Contaminantes Químicos em Alimentos. Portaria n 685, de 27 de agosto de 1998. Diário Oficial da União, Brasília, DF. 24 de setembro de 1998.

10. BRASIL. Ministério da Agricultura, Pecuária e Abastecimento. Plano nacional de controle de resíduos em produtos de origem animal. Secretaria de Defesa Agropecuária. Instrução normativa $n^{\circ}$ 42, de 20 de dezembro de 1999. Brasília, DF. 1999.

11. BRASIL. Ministério da Saúde. Regulamento técnico sobre padrões microbiológicos em alimentos. Agência Nacional da Vigilância Sanitária. Resolução RDC n 12, de 2 de janeiro de 2001.

12. BRASIL. Ministério do Meio Ambiente. Qualidade da água. Conselho Nacional do Meio Ambiente- CONAMA. Resolução 357, de 17 de março de 2005.

13. BREMNER, H.A. A convenient, easy-to-use system for estimating the quality of chilled seafood. Fish Processing Bulletin, v.7, p.59-70, July.1985.

14. BENNER, JR. R.A.; STARUSZKIEWICZ, W.F.; ROGERS, P.L.; OTWELL, W.S. Evaluation of putrescine, cadaverine, and indole as chemical indicators of decomposition in Penaeid shrimp. Journal of Food Science, v.68, n.7, p.2.1782.185, 2003.

15. CARDENAS BONILLA, A.; SVEINSDOTTIR, K.; MARTINSDOTTIR, E. Development of Quality Index Method (QIM) scheme for fresh cod (Gadus morhua) fillets and application in shelf life study. Food Control, v.18, n.4, p.352-358, May, 2007.

16. CHINIVASAGAM, H.N.; BREMNER, H.A.; WOOD, A.F.; NOTTINGHAM, S.M. Volatile components associated with bacterial spoilage of tropical prawns. International Journal of Food Microbiology, v.42, p.45-55, 1998. 
17. COOPER, P.L.; MARSHALL, M.R.; GREGORY III, J.F.; OTWELL, W.S. Íon cromatography for determining residual sulfite on shrimp. Journal of Food Science, v.55, n.4, p.924-928, 1986.

18. ESTEVES, E.; ANÍBAL, J. Quality Index Method (QIM): utilização da Análise Sensorial para determinação da qualidade do pescado. In: CONGRESSO DO ALGARVE, 13., Racal-Clube, Lagos. ACTAS... Portugal: Centro cultural de Lagos, 2007. p.365-373.

19. EUA. U.S. Food and Drug Administration. WARNER, C.R. ; DIACHENKO, G.W.; BAILEY, C. (Ed.) Sulfites: An Important Food Safety Issue. An update on regulatory status and methodologies .Center for food safety and applied nutrition, 2000. 3p. Disponível em: 〈http://vm.cfsan.fda.gov/ dms/fssulfit.html>. Acesso em: 01 Aug 2008.

20. EUA. Department of health and human services. Public health service. Center for food safety and applied nutrition. Office of food safety. Fish and fishery products hazards and controls guidance. 4 ed. EUA: Food and Agriculture Organization, 2011. 468p.

21. FAO. Food and Agriculture Organization of the United Nations. Capture production 1950-2005. FISHSTAT Plus - Universal software for fishery statistical time series, 2007. Disponível em: 〈http://www.fao.org/fishery/topic/16073〉. Acesso em: 27 Oct 2009.

22. FAO. Food and Agriculture Organization of the United Nations. The state of world fisheries and aquaculture - SOFIA. Rome: Fisheries and Aquaculture Department, 2008. 178p.

23. FAO. Food and Agriculture Organization of the United Nations. FAO yearbook 2010 - Fishery and Aquaculture Statistics. Rome: Fisheries and Aquaculture Department, 2012a. 81p. 
24. FAO. Food and Agriculture Organization of the United Nations. The state of world fisheries and aquaculture - SOFIA. Rome: Fisheries and Aquaculture Department, 2012b. 231p.

25. FOGAÇA, F.H.S.; SANT'ANA, L.S. Oxidação lipídica em peixes, mecanismo de ação e prevenção. Archives of Veterinary Science, v.14, n.2, p.17$127,2009$.

26. FURLAN, É.F.; TORRES, E.A.F.S. Segurança alimentar na cadeia produtiva do camarão sete-barbas (Xiphopenaeus kroyeri). In: SIMPÓSIO DE CIÊNCIA E TECNOLOGIA DE ALIMENTOS, 2., CONGRESSO DO INSTITUTO NACIONAL DE FRUTOS TROPICAIS, 1., Aracaju, SE. Anais...Sergipe: SBCTA, 2010 (CD-ROOM -ISBN: 978-85-63641-00-7)

27. FURLAN, É.F.; GALUZZI SILVA, M.C.; TOMITA, R.Y.; BARBOSA, K.O.; TORRES, E.F.S.. Avaliação da coloração de camarões sete-barbas (Xiphopenaeus kroyeri) nas frotas pesqueiras de Santos e Guarujá. In: SIMPÓSIO DE CONTROLE DA QUALIDADE DO PESCADO, 5., Santos, SP. Anais...São Paulo: Instituto dePesca, 2012. (CD-ROOM - ISSN: 1983-1854)

28. GARRIDO, L.R.; BENNER, R.A.; ROSS, M.P.; OTWELL, W.S. Quality/ shelflife assessment and consumer acceptance of freshwater, farm raised shrimp (Litopenaeus Vannamei). Disponível em: http://fshn.ifas.ufl.edu/seafood/sst/25thann/file07.pdf Acessado em: 15 Nov.2012

29. GERMANO, PM.L.; GERMANO, M.I.S.; OLIVEIRA, C.A.F. Qualidade do pescado. In: GERMANO, PM.L.; GERMANO, M.I.S. Higiene e vigilância sanitária dos alimentos. 3.ed. Cap 8. Barueri, SP: Manole, 2008. 1032p.

30. GÖKODLU, N.; ÖZDEN, Ö; ERKAN, N. Physical, chemical and sensory analysis of freshly harvested sardines (Sardina pilchardus) stored at $4^{\circ} \mathrm{C}$. Journal of Aquatic Food Product Technology, v.7, n.2, p.5-15, 1998. 
31. GONÇALVES, A.A.; JUNIOR, C.S.G.G. The effect of glaze uptake on storage quality of frozen shrimp. Journal of Food Engineering, n.90, p.285-290, 2009 .

32. GRAÇA LOPES, R.; SANTOS, E.P. DOS; SEVERINO-RODRIGUES, E.; BRAGA, F.M.S.; PUZZI, A. Aportes ao conhecimento da biologia e pesca do camarão sete-barbas (Xiphopenaeus kroyeri Heller, 1862) no litoral do Estado de São Paulo, Brasil. Boletim do Instituto de Pesca, v.33, n.1, p.63-84, 2007.

33. GRAM, L.; HUSS, H.H. Microbial spoilage of fish and fish products. International Journal of Food Microbiology, v.33, p.121-137, 1996.

34. HAARD, N.F. Control of chemical composition and food quality attributes of cultured fish. Food Research International, v.25, p.289-307, 1992.

35. HILLERY, B.R.; ELKINS, E.R.; WARNER, C.R.; DANIELS, D.; THOMAS, F. Optimized Monier-Williams Method for determination of sulfites in foods: collaborative study. J. A.O.A.C., v.72, n.3, p.470-475, 1989.

36. HORTON, L.R.; WRIGHT, B.; WRIGHT, E. International Food \& Agricultural Trade Policy Council. IPC Position Paper - Standards Series. 2008. Disponível em: <http://www.agritrade.org/Publications/documents/IPCStandardsPositionPaper.pdf $>$ Acesso em: 20 Oct. 2009.

37. HOWGATE, P.F. Quality assessment and quality control. In: AITKEN, A.; MACKIE, I.M.; MERRITT, J.H.; WINDSOR, M.L., (Eds). Fish Handling \& Processing. 2 ed. Edinburgh: Ministry of Agriculture, Fisheries \& Food, Torry Research Station, 1982. p.177-186. 
38. HUIDOBRO, A.; PASTOR, A.; TEJADA, M. Quality index method developed for raw gilthead seabream (Sparus aurata). Journal of Food Science, v.65, p.1202-1205, 2000.

39. HUSS, H.H. Assurance of seafood quality. Rome: FAO, 1993. 169p. (FAO Fisheries Technical Paper 334).

40. HUSS, H.H. Quality and quality changes in fresh fish. Rome: FAO, 1995. 195p. (FAO Fisheries Technical Paper 348).

41. HUSS, H.H.; ABABOUCH, L.; GRAM, L. Assessment and management of seafood safety and quality. Rome: FAO, 2004. 266p. (FAO Fisheries Techical Paper 444).

42. HYLDIG, G.; NIELSEN, J. QIM a tool for determination of fish freshness. In: SHAHIDI, F.; SIMPSON, B.K. Seafood Quality and Safety. Advances in the New Millennium. St John’s: ScienceTech Publishing Company, 2004. p.81-89.

43. IBAMA. Ministério do Meio Ambiente. Instituto Brasileiro do Meio Ambiente e dos Recursos Naturais Renováveis. Diretoria de uso Sustentável da Biodiversidade e Florestas. DIAS NETO, J. Coordenação-Geral de Autorização de uso e Gestão de Fauna e Recursos Pesqueiros.Proposta de Plano Camarões Marinhos no Brasil. Brasília, DF. 2011. 242p.

44. INSTITUTO DE PESCA. Informe da Produção Pesqueira Marinha e Estuarina do Estado de São Paulo: Julho 2011. Santos, SP.: Centro APTA Pescado Marinho, Instituto de Pesca, 2011. n.12, 4p.

45. KIRSCHNIK, P.G.; VIEGAS, E.M.M. Alterações na qualidade do camarão de água doce Macrobrachium rosenbergii durante estocagem em gelo. Ciência e Tecnologia de Alimentos,v.24, n.3, p.407-412, 2004. 
46. LAPA-GUIMARÃES, J. Aminas biogênicas, aminas voláteis, triptofano livre e uréia como indices químicos de qualidade e frescor do pescado. 2005. 114p. Tese (Doutorado em Tecnologia de Alimentos) - Faculdade de Engenharia de Alimentos, Universidade de Campinas, Campinas.

47. LEITÃO, M.F.F.; RIOS, D.P.A. Microbiological and chemical changes in freshwater prawn (macrobrachium rosembergii) stored under refrigeration. Brazilian Journal of Microbiology, v.31, p.178-183, 2000.

48. LIMA DOS SANTOS, C.A.M. Doenças transmitidas por pescado no Brasil. Revista Brasileira de Medicina Veterinaria, v.32, p.234-241, 2010.

49. LYHS, U. Microbiological methods. In: REHBEIN, H.; OEHLENSCHL AGER, J. (Eds) Fishery Products: Quality, Safety and Authenticity. Oxford: WileyBlackwell, 2009. p. 318-348.

50. MACHADO, R.M.D.; TOLEDO, M.C.F.; VICENTE, E. Sulfitos em alimentos. Brazilian Journal of Food Technology, v.9, n.4, p. 265-275, 2006.

51. MACHADO, T.M.; FURLAN, E.F.; NEIVA, C.R.P.; CASARINI, L.M.; ALEXANDRINO DE PÉREZ, A.C.; LEMOS NETO, M.J.; TOMITA, R.Y. Fatores que afetam a qualidade do pescado na pesca artesanal de municípios da costa sul de São Paulo, Brasil. Boletim do Instituto de Pesca, São Paulo, v.36, n.3, p. 213-223, 2010.

52. MARTINSDÓTTIR, E.; SVEINSDÓTTIR, K.; LUTEN, J.; SCHELVISSMIT, R.; HYLDIG, G. Sensory evaluation of fish freshness. Reference manual for the fish sector. The Netherlands: QIM Eurofish, 2001. Disponível em: www.qimeurofish.com. Acesso em: 11 Dec. 2011

53. MARTINSDÓTTIR, E. Quality management of stored fish. In: BREMNER, H.A. (Ed.). Safety and Quality Issues in Fish Processing. England: Woodhead Publishing Limited, 2002. p. 360-378. 
54. MARTINSDÓTTIR, E.; SVEINSDÓTTIR, K.; LUTEN, J.; SCHELVISSMIT, R.; HYLDIG, G. Development of QIM - past and future. In: LUTEN, J.; OEHLENSCHLAGER, J.; OLAFSDOTTIR, G. Quality of fish from catch to consumer: Labelling, Monitoring and Traceability. The Netherlands: Wageningen Academic Publ, 2003. p. 265-271

55. MARTINSDÓTTIR, E.; SCHELVIS, R.; HYLDIG, G.; SVEINSDÓTTIR, K. Sensory evaluation of seafood: general principles and guidelines. In: REHBEIN, H.; OEHLENSCHLÄGER, J. (Eds.). Fishery products: quality, safety and authenticity. Oxford: Blackwell Publishing, 2009. p. 411-424.

56. MENDES, R.; GONÇALVES, A.; PESTANA, J.; PESTANA, C. Indole production and deepwater pink shrimp (Parapenaeus longirostris) decomposition. European Food Research and Technology, v.221, n.3-4, p.320-328, 2005.

57. MONTERO, P.; LOPEZ-CABALlERO, M.E.; PEREZ-MATEOS, M. The effect of inhibitors and high pressure treatment to prevent melanosis and microbial growth on chilled prawns (Penaeus japonicus). Journal of Food Science, v.66, p.1201-1206, 2001.

58. MONTERO, P.; MARTÍNEZ-ÁLVAREZ, O.; GÓMEZ-GUILLÉN, M.C. Effectiveness of onboard application of 4-hexylresorcinol in inhibiting melanosis in shrimp (Parapenaeus longirostris). Journal of Food Science, v.69, n.8, p.643-647, 2004.

59. MORAIS, C. Causa e prevenção da "mancha negra" em camarões. Boletim do ITAL, Campinas, v.21, n.2, p.121-135, 1984.

60. MORAIS, C. Efeito do ácido cítrico e metabissulfito de sódio na qualidade do camarão mantido em gelo de refrigeração. Coletânea do Instituto de Tecnologia de Alimentos; v.25, n.1, p.34-45, 1995.

61. MORTON, R.D. Aerobic Plate Count. In: DOWNES, F.P.; ITO, K. Compendium of Methods for the Microbiological Examination of Foods, 4.ed. Washington, DC: American Public Health Association, 2001.

62. MOURA, A.; DEL BEN MAYER, M.; LANDGRAF, M.; TENUTA FILHO, A. Qualidade química e microbiológica de camarão-rosa comercializado em São Paulo. Brazilian Journal of Pharmaceutical Sciences, v.39, n.2, p.203-208, 2003. 
63. NUNES, A.J.P. O cultivo de camarões marinhos no Nordeste do Brasil. Panorama da Aqüicultura, v.11, p.29-33, 2001.

64. NUNES, M.L.; BATISTA, I. Aplicação do índice de qualidade (QIM) na avaliação da frescura do pescado. Algés, Lisboa: Divulgação IPIMAR, 2004. Disponível em: http://ipimar-iniap.ipimar.pt/servicos/biblioteca/edicoes/ipimardivulgacao/Folheto29.pdf. Acesso em: 20 out. 2009.

65. OGAWA, M.; DINIZ, F.M. Tecnologia do pescado na região nordeste. In: OGAWA, M.; MAIA, E.L. Manual da pesca. Cap. 17.2. São Paulo: Varela, 1999, p 398-404.

66. OGAWA, M.; MAIA, E.L. Manual da pesca. São Paulo: Varela, 1999, $464 \mathrm{p}$.

67. OGAWA, N.B.P.; ARAÚJO, I.W.F.; LUCENA, L.H.L.; MAIA, E.L.; OGAWA, M. Teor residual de SO2 em camarões congelados exportados pelo estado do Ceará. Boletim Técnico do CPNOR, Belém, v.3, n.1, p.191-196, 2003.

68. ÓLAFSDÓTTIR, G.; MARTINSDÓTTIR, E.; OEHLENSCHLÄGER, J.; DALGAARD, P.; JENSEN, B.; UNDELAND, I.; MACKIE, I.M.; HENEHAN, G.; NIELSEN, J.; NIELSEN, H. Methods to evaluate fish freshness in research and industry. Trends in Food Science and Technology, v.8, p. 258-265, 1997.

69. ÖNAL A. A review: current analytical methods for the determination of biogenic amines in foods. Food Chemistry, v.103, p.1475-1486, 2007.

70. OTWELL,W.S.; FLICK, Jr.G.J. A HACCP program for raw, cultured Penaeid shrimp. USA: Florida Sea Grant College Program, 1995. p.218-226. (FLSGP-R-95-001 C3).

71. OTWELL, W.S.; GARRIDO, L.; GARRIDO, V.; BENNER, R. Farm-raised shrimp good aquacultural practices for product quality and safety. Food Science \& Human Nutrition Department and FL Sea Grant College Program. Gainesville: University of Florida, 2001.71p (FL 32611). 
72. PÁDUA, H.B. de. Informações sobre os coliformes totais/ fecais e alguns outros organismos indicadores em sistemas aquáticos - Aqüicultura, 2003. 20p. Disponível em: <http:// www.setorpesqueiro.com.br>. Acesso em: 12 ago 2009.

73. PAIVA, R.I.; RODRIGUES, J.; AMORIM, L.A. Carcinicultura Brasileira em 2003. Disponível em: <http://www.abccam.com.br/download/carci03.pdf $>$. Acesso em: 10 out 2005.

74. PINHEIRO, J.S.; CINTRA, I.H.A. Tecnologia do Pescado na Região Norte. In: OGAWA; M.; MAIA, E.L. Manual de Pesca. Cap.17.3. São Paulo: Varela, 1999, p.411-417.

75. PORNRAT, S.; SUMATE, T.; ROMMANEE, S.; SUMOLAYA, K.; KERR, W.L. Changes in the ultrastructure and texture of prawn muscle (Macrobrachuim rosenbergii) during cold storage. LWT - Food Science and Technology, v.40, n.10, p.1747-1754, 2007.

76. SAITO, T.; ARAI, K.; MATSUYOSHI, M. A new method for estimating the freshness of fish. Bull. Jap. Soc. Sci. Fish., v.24, p.749-50, 1959.

77. SEVERINO-RODRIGUES, E.; PITA, J.B.; GRAÇA-LOPES, R.; COELHO, J.A.P.; PUZZI, A. Aspectos biológicos e pesqueiros do camarão sete-barbas (Xiphopenaeus kroyeri) capturado pela pesca artesanal no litoral do Estado de São Paulo. Boletim do Instituto de Pesca, São Paulo, v.19, p.67-81, 1993.

78. SHAHIDI, F.; SIMPSON, B.K. Seafood Quality and Safety. Advances in the New Millennium. St John’s: ScienceTech Publishing Company, 2004. 381p.

79. SHRÖDER, U. Challenges in traceability of seafood. Journal für Verbraucherschutz und Lebensmittelsicherheit, v.3, n.1, p.45-48, 2008.

80. SORENSEN, J.; GLOB, E. Influence of benthic fauna on trimethylamine concentrations in coastal marine sediments. Marine Ecology Progress Series, v.39, p.15-21, 1987. 
81. THAMPURAN, N.; GOPAKUMAR, K. Impact of handling practices on the microbial quality of shrimp (Metapenaeus dobsoni). Roma: FAO, 1990. p. 4752. (FAO Fisheries Report).

82. VALENTINI, H.; D'INCAO, F.; RODRIGUES, L.F.; REBELO NETO, J.E.; RAHN, E. Análise da pesca do camarão-rosa Penaeus brasiliensis e Penaeus paulensis nas regiões Sudeste e Sul do Brasil. Atlântica, Rio Grande, v.13, n.1, p.143-157, 1991a.

83. VALENTINI, H.; D'INCAO, F.; RODRIGUES, L.F.; REBELO NETO, J.E.; DOMIT, L.G. Análise da pesca do camarão sete-barbas Xiphopenaeus kroyeri nas regiões Sudeste e Sul do Brasil. Atlântica, Rio Grande, v.13, n.1, p.171-177, 1991b.

84. VAZ-PIRES, P. Tecnologia do Pescado, Porto-PT, 2006. 211p. Apostila da disciplina de Tecnologia do Pescado. Instituto de Ciências Biomédicas Abel Salazar Universidade do Porto.

85. VIEIRA, R.H.S.F. Microbiologia do Pescado. In: GONÇALVES, A.A. Tecnologia do Pescado: ciência, tecnologia, inovação e legislação, São Paulo: Atheneu, 2011. p. 33-41.

86. VYNCKE, W. Direct determination of the thiobarbituric acid value in trichloracetic acid extracts of fish as a measure of oxidative rancidity. Fette Seifen Anstrichmittel, v.72, n.12, p.1084-1087, 1970.

87. WHO. WORLD HEALTH ORGANIZATION. WHO FOOD ADDITIVES. Safety evaluation of certain food additives. In: Meeting of the Joint FAO/WHO (JECFA), 69., Geneva. Proceedings...Geneva: WHO, IPCS - International Programme on Chemical Safety, 2009. 259p.

88. YAMANAKA, H.; SHIOMI, K.; KIKUCHI, T. Agmatine as a potential index of freshness of common squid (Todarodes pacificus). Journal of Food Science, v.52, n.4, p.936-938, 1987. 
89. YOKOYAMA, V.A. Qualidade do camarão da espécie Xyphopenaeus kroyeri mediante a ação dos agentes antimelanóticos. 2007. 124p. Dissertação (Mestrado em Ciência e Tecnologia de Alimentos) - Departamento de Agroindústria, Alimentos e Nutrição, Escola Superior de Agricultura Luiz de Queiroz, Universidade de São Paulo, Piracicaba, SP. 


\section{CAPÍTULO 2 - QUALIDADE DO CAMARÃO SETE-BARBAS (Xiphopenaeus kroyeri, HELLER, 1862) DESEMBARCADO NA REGIÃO METROPOLITANA DA BAIXADA SANTISTA, SP - BRASIL.}

\section{Resumo}

São crescentes as exigências dos consumidores e entidades sanitárias quanto a qualidade dos produtos alimentícios disponibilizados no mercado. No Brasil, não existe um regulamento técnico de produção, identidade e qualidade específico para o camarão marinho Xiphopenaeus kroyeri, comprometendo a eficácia da sua qualificação. Neste sentido, camarões sete-barbas desembarcados na região metropolitana da Baixada Santista, SP, foram avaliados quanto aos níveis de Bases Nitrogenadas Voláteis Totais (BNVT), dióxido de enxofre (SO2), Trimetilamina (TMA), Mercúrio (Hg), bem como, quanto às contagens de Staphylococcus aureus, Coliformes totais e fecais, Salmonella sp; determinação do pH, aceitação sensorial e a adequação destes parâmetros frente aos limites regulados para o mercado nacional. As substancias reativas ao ácido tiobarbitúrico (TBARS), a biometria e a mensuração instrumental da cor e textura foram também determinadas. Para que o camarão marinho $X$. kroyeri seja qualificado para o consumo sugere-se: $\mathrm{pH} \leq 7,7$; BNVT $\leq 35$ mg N. 100g-1 de músculo e firmeza (entre o primeiro e segundo segmento muscular) $>6 \mathrm{~N}$; valores superiores são sugeridos para os camarões recém desembarcados. Há necessidade de melhorias nas práticas a bordo das embarcações pesqueiras.

Descritores: Crustáceos, Inocuidade, Legislação, Segurança do alimento, Setebarbas. 
QUALITY OF SEABOB SHRIMP (Xiphopenaeus kroyeri, Heller, 1862) LANDED IN THE METROPOLITAN REGION OF THE SANTOS, SÃO PAULO - BRAZIL.

\begin{abstract}
The quality of food products are demands from consumers and health authorities. In Brazil, there are not a specific standard for the marine shrimp $X$. kroyeri, compromising the product's qualification. Were evaluated severals whole shrimp landings in Santos, SP (BR), in the levels of total volatile basic nitrogen (TVB-N), sulfur dioxide $\left(\mathrm{SO}_{2}\right)$, trimethylamine (TMA), mercury $(\mathrm{Hg})$ and $\mathrm{pH}$, quantification of Staphylococcus aureus, total and thermotolerants coliforms, Salmonella sp; sensory acceptance test and their suitability, taking into account the regulates limits for the local market. Thiobarbituric acid reactive substances (TBA) and instrumental measurement of color and texture were also determined. To qualify the marine shrimp $X$. kroyeri as suitable for consumption are suggested: $\mathrm{pH} \leq 7.7$, TVB-N $\leq 35 \mathrm{mg} \mathrm{N} \cdot 100 \mathrm{~g}^{-1}$ and muscle firmness between the first and second segment $>6 \mathrm{~N}$, being desirable higher values for recently landed shrimps. It is necessary to improve practices onboard of fishing vessels.
\end{abstract}

Key words: Shellfish, Food Security, Legislation, Food Safety, Sea-bob. 


\subsection{INTRODUÇÃO}

O camarão é um excelente candidato a fonte de proteína alimentar, em vista da sua popularidade, valor agregado e por ser um produto de elevada demanda pelos consumidores e importadores dos EUA, Europa e Japão.

O comércio global de camarões foi de US\$ 13 bilhões para a indústria em 2008. Em 2006, a importação de camarões somente pelos EUA excedeu US\$ 4 bilhões (HORTON; WRIGHT; WRIGHT, 2008). De acordo com os mesmos autores, este panorama indica que os países em desenvolvimento podem obter comparável sucesso na comercialização de camarões se investirem em recursos de infraestrutura industrial e ações reguladoras governamentais, necessárias para produção de alimentos seguros e para vencer a perícia, com vistas a se conseguir a conformidade reguladora.

Para Gonçalves (2010), a confiança dos consumidores, a adequação dos mercados e da produção são essenciais para a rentabilidade das empresas, contribuindo para o sucesso e sustentabilidade do setor aquícola. Além da melhoria das condições de pesca e de aproveitamento da produção, a estratégia de desenvolvimento do setor está na oferta de garantias aos consumidores e intervenientes na comercialização no que diz respeito à qualidade, inovação e diversificação de produtos, atendendo a demanda de forma responsável, aproveitando a produção integralmente e minimizando perdas.

As estatísticas de produção e comércio indicam a importância da pesca do camarão marinho Xiphopenaeus kroyeri, que se encontra entre as 10 espécies de camarão mais capturadas em volume no mundo, tendo atingido 41.716 t em 2010 (FAO, 2007; 2012a). Em 2011, foi a segunda principal espécie de pescado marinho desembarcada no Estado de São Paulo, Brasil (INSTITUTO DE PESCA, 2011), um dos maiores produtores da espécie no país (IBAMA, 2011).

O Xiphopenaeus kroyeri é tradicionalmente capturado com o emprego do arrasto de fundo. Por habitar águas costeiras rasas é, principalmente, acessível à 
pesca de pequena escala, embora embarcações consideradas industriais façam parte dessa frota, em especial nos estados de São Paulo e de Santa Catarina (SEVERINORODRIGUES et al., 1993).

A valorização dos produtos pesqueiros é uma tendência mundial e crescente entre consumidores e autoridades sanitárias, principalmente, no que diz respeito à qualidade dos produtos oferecidos. Sendo, a inocuidade o principal aspecto que os preocupa, especialmente quando consideramos a possibilidade de contaminação por produtos químicos, como agrotóxicos, aditivos alimentares e antibióticos.

O uso excessivo de aditivos alimentares, como os sulfitos na prevenção da melanose em camarões, a deficiente qualidade do camarão desembarcado e comercializado no Brasil, bem como, o impacto da manipulação inadequada sobre a contaminação dos camarões vem sendo apontados em alguns estudos (THAMPURAN; GOPAKUMAR, 1990; MOURA et al., 2003; OGAWA et al., 2003; YOKOYAMA, 2007; FURLAN; TORRES, 2010; MACHADO et al., 2010; FURLAN et al., 2012).

Aliando esta problemática à deficiente fiscalização dos produtos pesqueiros destinados ao mercado interno, bem como, a antiga legislação nacional vigente para o pescado (BRASIL, 1952) e a falta de especificidade da mesma frente às espécies exploradas comercialmente no país, vê-se a necessidade de desenvolvimento de ferramentas que contribuam para redução dos riscos associados ao consumo do pescado.

O setor pesqueiro brasileiro também apresenta carência por métodos de padronização rápida para avaliação da qualidade do pescado e seus produtos. No Brasil, o principal método utilizado pelas indústrias e pelo serviço de inspeção para a avaliação do frescor em pescado in natura ou de produtos derivados é o sensorial, visto que os demais métodos existentes, físicos, químicos e microbiológicos, muitas vezes são morosos e/ ou de alto custo.

No entanto, não existe um regulamento técnico específico de produção, identidade e qualidade para o camarão $X$. kroyeri,comprometendo a eficácia desta avaliação

O que há no Brasil é uma crescente preocupação em aumentar a oferta de alimentos com condições físicas, químicas e microbiológicas satisfatórias, 
apresentando assim maior qualidade e segurança. Portanto, torna-se importante o estabelecimento de um regulamento técnico com padrões de qualidade para o camarão $X$. kroyeri, que ofereça informação necessária e de forma simples, viabilizando sua aplicação na rotina dos inspetores e das plantas de processamento.

Neste contexto, o presente trabalho objetivou analisar a qualidade do camarão sete-barbas nos principais desembarques da região Metropolitana da Baixada Santista e verificar dentre os parâmetros de qualidade atualmente legislados os mais adequados para qualificá-lo. 


\subsection{MATERIAL E MÉTODOS}

\subsubsection{DELINEAMENTO DO ESTUDO}

Para a caracterização da qualidade do camarão marinho Xiphopenaeus kroyeri desembarcado na região Metropolitana da Baixada Santista, SP., realizou-se um levantamento prévio dos desembarques deste camarão na região, em termos de produção e frota pesqueira, definindo assim os pontos de coleta.

O levantamento da produção de camarão sete-barbas e a definição dos pontos de amostragem foram conduzidos por consultas a especialistas e aos relatórios da estatística pesqueira do Instituto de Pesca/Apta/SAA.

O Instituto de Pesca é uma instituição vinculada à Agência Paulista de Tecnologia dos Agronegócios (Apta) da Secretaria de Agricultura e Abastecimento do Estado de São Paulo (SAA), responsável pela execução do Programa de Monitoramento da Atividade Pesqueira - PMAP. Este programa é coordenado e executado pelo Laboratório de Estatística Pesqueira (Santos-SP), em conjunto com os Núcleos de Pesquisa e Desenvolvimento do Litoral Norte (Ubatuba-SP) e Sul (Cananéia-SP).

Os dados pesqueiros são obtidos por método censitário, em entrevistas com mestres de embarcações e pescadores e pela verificação de registros de descarga de pescado em um total de 216 locais nos 16 municípios da costa paulista.

Assim, após a definição dos principais pontos de desembarque e dos locais das amostragens, iniciaram-se as colheitas das amostras para a caracterização da qualidade do camarão sete-barbas, conforme o fluxograma (Figura 3). 


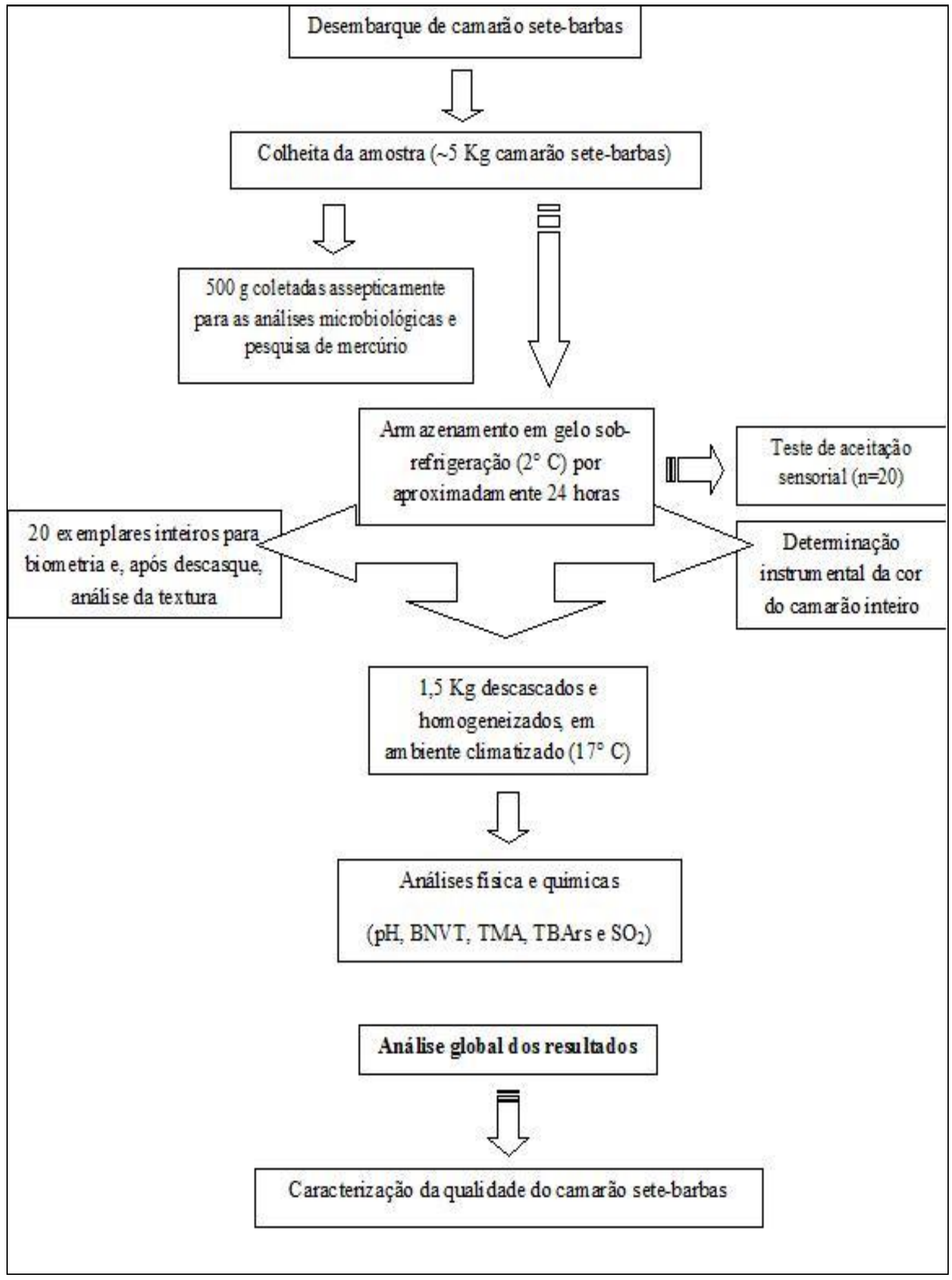

Figura 3. Fluxograma dos procedimentos para a caracterização da qualidade do camarão sete-barbas desembarcado na Baixada Santista, SP - Brasil 


\subsubsection{MATÉRIA-PRIMA}

Para a caracterização da qualidade do camarão marinho Xiphopenaeus kroyeri foram colhidas vinte amostras do camarão in natura nos principais desembarques da Baixada Santista, a saber, nos municípios de Peruíbe, Itanhaém, Bertioga, Santos e Guarujá, no período de novembro de 2011 a fevereiro de 2012.

As amostras ( 5 kg de cada embarcação) foram colhidas de distintos desembarques, acondicionadas em sacos plásticos estéreis e transportadas ao laboratório em caixas isotérmicas adequadamente higienizadas e com gelo.

No laboratório, os camarões inteiros foram acondicionados em caixas de polipropileno perfuradas e então, cobertos com um filme plástico seguido de gelo em escama (Figura 4). Todas as amostras foram estocadas a $2 \pm 2^{\circ} \mathrm{C}$ até as análises $(\sim 24$ horas).

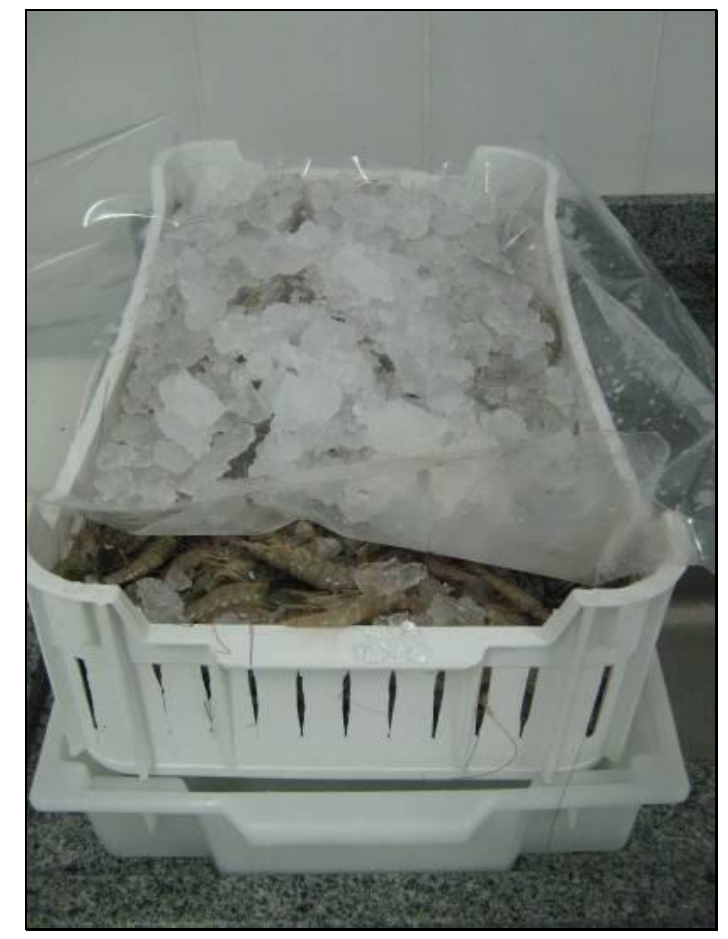

Figura 4. Amostras de camarão sete-barbas. 
Para a realização dos ensaios microbiológicos, $500 \mathrm{~g}$ de camarão foram separados assepticamente, e acondicionadas em sacos plásticos estéreis, que foram lacrados e então, transportados ao laboratório de microbiologia em caixa isotérmica, previamente higienizada, identificada e com gelo.

Para os ensaios físico e químicos, o preparo das amostras consistiu no descasque de aproximadamente $1,5 \mathrm{Kg}$ do camarão em ambiente climatizado $\left(\sim 17^{\circ}\right.$ C) e homogeneização da porção cárnea em cutter por 1 min., incorporação das porções menos trituradas com auxílio de espátula e mais 1 min. em cutter. Obtendose uma pasta (amostra homogeneizada) que foi utilizada para as determinações do pH, BNVT, TMA e TBARS.

A determinação da qualidade física e química dos camarões foi baseada na realização de ensaios na maioria normatizados e/ou metodologias oficiais.

\subsubsection{ANÁLISES FÍSICAS, FÍSICO QUÍMICA E QUÍMICAS}

\subsubsection{Biometria}

Foram realizadas medições do comprimento dos camarões com auxílio de um paquímetro. Para cada amostra foram tomados aleatoriamente 20 espécimes.

\subsubsection{Valor do $\mathrm{pH}$}

A determinação eletrométrica do $\mathrm{pH}$ foi realizada em triplicata, segundo as Normas Analíticas do Instituto Adolfo Lutz (2008), que fundamenta-se na medida da 
concentração de íons hidrogênio em 10 gramas de amostra homogeneizada em 100 $\mathrm{mL}$ de água destilada.

\subsubsection{Bases Nitrogenadas Voláteis Totais (BNVT)}

Foram determinadas em triplicatas, de acordo com o método oficial do Ministério da Agricultura, Pecuária e Abastecimento (BRASIL, 1981). Utilizou-se $50 \mathrm{~g}$ da amostra homogeneizada, que após a precipitação do nitrogênio protéico com $150 \mathrm{~mL}$ de solução de ácido tricloroacético (TCA) 5\%, foi filtrada em filtro qualitativo, resultando em um extrato contendo o nitrogênio volátil. Então, $5 \mathrm{~mL}$ do extrato filtrado foi alcalinizado com hidróxido de sódio $(\mathrm{NaOH}) 2 \mathrm{M}$ e destilado a vapor, utilizando-se um destilador micro-Kjeldahl (Tecnal, Brasil). O destilado foi recebido em solução de ácido bórico, até um volume aproximado de $50 \mathrm{~mL}$ e, sequencialmente, titulado com solução de ácido padronizado $(\mathrm{HCl} 0,01 \mathrm{~N})$, em presença do indicador ácido rosólico, até a viragem da cor amarela para o cor rosa. Resultando no teor de nitrogênio proveniente de substâncias básicas voláteis totais (BNVT), como amônia e aminas de cadeia curta, que se acumulam no músculo do pescado após a morte. Os resultados dos vários compostos foram expressos em mg N.100 $\mathrm{g}^{-1}$ de músculo, e obtidos pela equação que segue:

$$
\mathrm{BNVT}=\frac{14 \times(150+\mathrm{A}) \times(5-\mathrm{V}) \times \mathrm{fc} \times \mathrm{N} \times 100}{\operatorname{Va} \times \mathrm{P}}
$$

Onde, 14 = Eqg de nitrogênio; 150 = volume $(\mathrm{mL})$ da solução de TCA a 5\%; $\mathbf{A}=$ conteúdo de água contido na amostra expressa $(\mathrm{mL}) ;(\mathbf{5}-\mathbf{V})=(\mathbf{5} \mathbf{~ m L ~ H C L}-\mathbf{X}$ $\mathbf{m L ~} \mathrm{NaOH})=$ volume $(\mathrm{mL})$ de solução de ácido clorídrico $0,01 \mathrm{~N}$ adicionado no erlenmeyer que recebe o destilado e subtraídos do volume (mL) de $\mathrm{NaOH} 0,01 \mathrm{~N}$ gasto na titulação $(\mathbf{V}) ; \mathbf{f c}=$ fator de correção da solução de $\mathrm{HCl} 0,01 \mathrm{~N} ; \mathbf{N}=$ normalidade da solução de $\mathrm{HCl}(\mathrm{mol} / \mathrm{L}) ; \mathbf{V a}=$ volume $(\mathrm{mL})$ da alíquota e $\mathbf{P}=$ massa da amostra em gramas. 


\subsubsection{Trimetilamina (TMA)}

A determinação da TMA foi realizada sequencialmente a metodologia de BNVT. Após titulação, as triplicatas do extrato foram acrescidas da solução de FA $16 \%$ neutralizada, $1 \mathrm{~mL}$ de FA para cada $10 \mathrm{~mL}$ do extrato. O FA reage com as aminas, exceto a TMA então, titulou-se o ácido liberado (equivalente à trimetilamina) com solução de $\mathrm{NaOH} 0,01 \mathrm{~N}$ até a viragem de incolor para a cor rosa. Anotou-se o volume ( $\mathbf{V}^{\prime}$ ), em mL, da solução de $\mathrm{NaOH}$ 0,01N gasto na $2^{\mathrm{a}}$ titulação, que corresponde ao volume $(\mathrm{mL})$ do ácido liberado, como proposto em Brasil (1981). Os resultados de TMA foram expressos em mg N.100 g $\mathrm{g}^{-1}$ de músculo, e obtidos pela equação abaixo:

$$
\mathrm{TMA}=\frac{14 \times(150-5-\mathrm{A}) \times V^{\prime} \times \mathrm{fc} \times \mathrm{N} \times 100}{\operatorname{Va} \times \mathrm{P}}
$$

Onde: $\mathbf{1 4}$ = Eqg de nitrogênio; 5 = volume $(\mathrm{mL})$ da solução de FA a 16\%; $\mathbf{3 0 0}=$ volume $(\mathrm{mL})$ da solução de TCA a $5 \% ; \mathbf{A}=$ conteúdo de água na amostra expressa $(\mathrm{mL}) ; \mathbf{V}^{\prime}=$ volume $\left(\mathrm{mL}\right.$, de $\mathrm{NaOH} 0,01 \mathrm{~N}$ gasto na $2^{\mathrm{a}}$ titulação; $\mathbf{f} \mathbf{c}=$ fator de correção de solução de $\mathrm{HCl}$ 0,01 N; N= Normalidade da solução de $\mathrm{HCl}$ 0,01N; Va = volume da alíquota $(\mathrm{mL})$ e $\mathbf{P}=$ massa da amostra $(\mathrm{g})$.

\subsubsection{Substâncias reativas ao ácido tiobarbitúrico (TBARS)}

Determinação quantitativa realizada em triplicatas, utilizando-se $10 \mathrm{~g}$ da amostra homogeneizada. Após extração da amostra com $50 \mathrm{~mL}$ de ácido tricloroacético (TCA) 7,5\% e filtração, em filtro qualitativo, tomou-se uma alíquota de $5 \mathrm{~mL}$ do extrato para um tubo de rosca e então, foram adicionados $5 \mathrm{~mL}$ de ácido 2-tiobarbitúrico (TBA) 0,02 M, que após o fechamento do tubo de rosca e a 
manutenção em banho-maria a $100^{\circ} \mathrm{C}$, por 40 min., reagiu com o aldeído malônico (AM), produto da decomposição dos hidroperóxidos, formando uma pigmentação rosa, cuja intensidade indicou o grau de oxidação e foi determinada em espectrofotômetro 700 Plus (FEMTO, Brasil), com $\lambda=538 \mathrm{~nm}$, de acordo com Vyncke (1970). Os teores de TBARS foram expressos em mg AM. $\mathrm{Kg}^{-1}$ do músculo e calculados pela fórmula:

$$
\text { TBARS }=\frac{\text { Absorbância } / F c}{(5 / 50) * P}
$$

Onde: Absorbância = média da leitura das triplicatas medidas em espectrofotômetro; $\mathbf{F c}=$ y da equação da reta, proveniente da curva de calibração $(\mu \mathrm{g} / \mathrm{mL}) ; \mathbf{5}=$ volume $(\mathrm{mL})$ do extrato; $\mathbf{5 0}=$ volume $(\mathrm{mL})$ de solução de TCA a 7,5\% e $\mathbf{P}=$ massa da amostra $(\mathrm{g})$.

\subsubsection{Teor residual de Dióxido de Enxofre $\left(\mathrm{SO}_{2}\right)$}

A matéria-prima para a determinação do residual de $\mathrm{SO}_{2}$ foi obtida a partir da homogeneização de $1,5 \mathrm{Kg}$ de camarão descascado e descabeçado em cutter. $\mathrm{O}$ material foi mantido sob congelamento a $-20^{\circ} \mathrm{C}$ e descongelado, sob-refrigeração, para a análise pelo método Monier Willians otimizado (HILLERY et al., 1989), que converte as formas de sulfito em dióxido de enxofre (BRASIL, 2011). O método consiste na homogeneização de $50 \mathrm{~g}$ do músculo triturado com $100 \mathrm{~mL}$ de solução de etanol a $5 \%$ e $400 \mathrm{~mL}$ de água deionizada. A mistura foi aquecida, durante $1 \mathrm{~h}$ e 40 min., em meio ácido (90 mL da solução de $\mathrm{HCl} 4 \mathrm{M}$ ) para liberação do $\mathrm{SO}_{2}$; em ambiente desoxigenado pelo borbulhamento de $\mathrm{N}_{2}$ e temperatura aproximada de $15^{\circ} \mathrm{C}$. O SO $\mathrm{SO}_{2}$ liberado foi recebido em solução de peróxido de hidrogênio $\left(\mathrm{H}_{2} \mathrm{O}_{2}\right) 3 \%$, previamente titulada com solução de $\mathrm{NaOH}$ 0,01 M (até amarelar pela presença do indicador vermelho de metila), sendo oxidado a ácido sulfúrico $\left(\mathrm{H}_{2} \mathrm{SO}_{4}\right)$, que por sua 
vez foi titulado com uma solução padrão de $\mathrm{NaOH}$ 0,01 M, utilizando-se vermelho de metila como indicador. O conteúdo do sulfito é relacionado ao conteúdo de $\mathrm{H}_{2} \mathrm{SO}_{4}$ formado na titulação e calculado pela fórmula:

$$
\mathrm{SO}_{2}=\frac{32,02 \times \mathrm{V} \times 0,01 \times \mathrm{fc} \times 1000}{\mathrm{~m}}
$$

Onde: 32,02 $=$ mEqg do $\mathrm{SO}_{2} ; \mathbf{V}=$ volume $(\mathrm{ml})$ gasto da solução de $\mathrm{NaOH}$ 0,01 M na titulação; $\mathbf{0 , 0 1}=$ concentração da solução de $\mathrm{NaOH}(\mathrm{mol} / \mathrm{L}) ; \mathbf{f c}=$ fator de correção para a solução de $\mathrm{NaOH} ; \mathbf{m}=$ massa de amostra utilizada (g).

\subsubsection{Determinação instrumental da cor}

A determinação colorimétrica foi realizada com auxílio de um colorímetro portátil CR-400 (Konica Minolta, Japão - Figura 5), programado para fazer 3 medições (3 disparos de flashes sequenciais) utilizando o iluminante D65. Camarões inteiros in natura foram acondicionados em uma cápsula preta (Figura 5), que acompanha o equipamento utilizado para a medição, de forma a cobrir toda a superfície da cápsula. O colorímetro foi calibrado com uma placa de porcelana branca padrão e a coloração expressa em coordenadas CIELab. Neste sistema L* representa a luminosidade, numa escala de 0-100 pontos (do preto ao branco), a* é a posição entre o vermelho (+) e o verde (-) e b* a posição entre o amarelo (+) e o azul (-). A intensidade da cor foi expressa em valor croma ( $\left.C^{*} \mathrm{ab}\right)$. Para cada amostra (Figura 5) foram realizadas 5 medições $(n=5)$ e o valor médio de cada amostra foi usado para o cálculo de $\mathrm{C}^{*}$ através da fórmula:

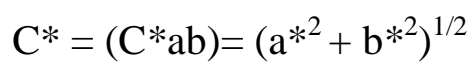



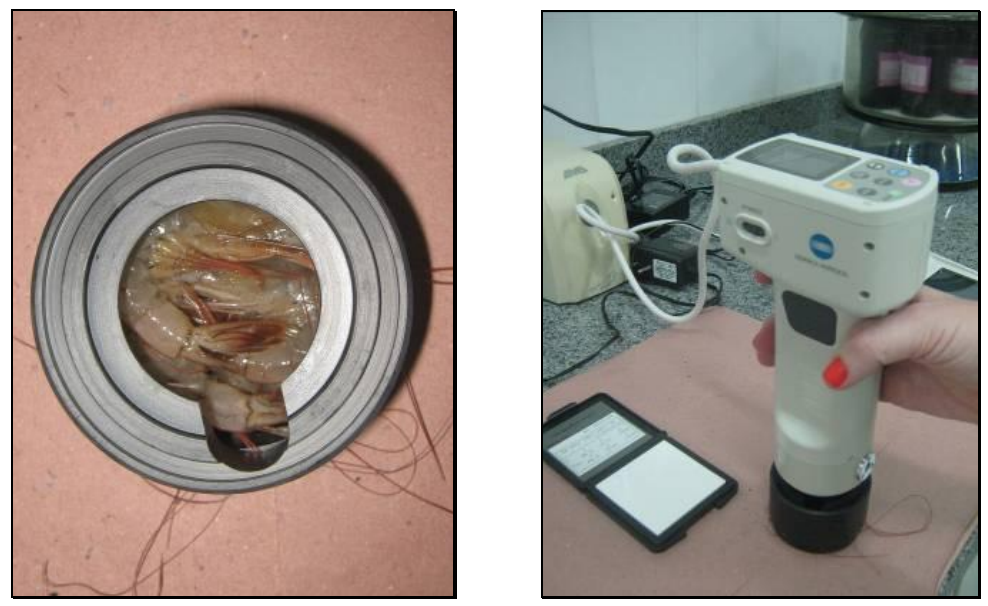

Figura 5. Amostra em cápsula preta, colorímetro CR-400 e placa de calibração (branco).

\subsubsection{Determinação instrumental da textura}

Para esta determinação, os procedimentos de preparo das amostras foram embasados em Niamnuy; Devahastin, e Soponronarit (2008). Camarões descabeçados e descascados tiveram a firmeza determinada por uma compressão no primeiro centímetro após a inserção do cefalotórax, região entre o primeiro e o segundo segmentos da cauda dos camarões (Figura 6). Foi utilizado um texturômetro TA Plus (LLOYD, Alemanha) equipado com uma sonda cilindrica de 8,0 $\mathrm{mm}$ de diâmetro, acoplada a uma célula de carga de 100 N. Realizou-se uma compressão de $4 \mathrm{~mm}$ a uma velocidade de $0,8 \mathrm{~m} \cdot \mathrm{s}^{-1}$, em 20 espécimes para cada amostra $(\mathrm{n}=20)$.

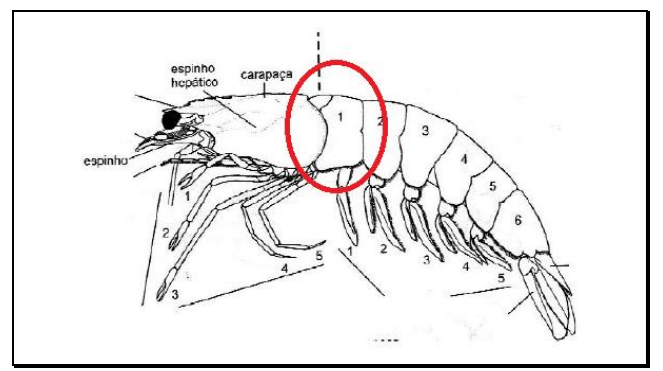

Figura 6. Ilustração de um camarão e destaque da região do corte efetuado para avaliação da textura. 


\subsubsection{Mercúrio $(\mathrm{Hg})$}

Pesou-se aproximadamente $1 \mathrm{~g}$ da amostra homogeneizada de camarão setebarbas e procedeu-se a digestão em sistema fechado, assistida por microondas, dos compostos orgânicos utilizando-se uma mistura de ácido nítrico, $\mathrm{H}_{2} \mathrm{SO}_{4} \mathrm{e}_{2} \mathrm{O}_{2}$, bem como, a dissolução dos metais e outros elementos presentes na amostra, segundo a A.O.A.C. (HORWITZ, 2005). Avolumou-se com água deionizada e homogeneizouse a solução obtida. Filtrou-se a solução em tubo de ensaio e a atomização da solução resultante foi realizada no espectrômetro de emissão por plasma (ICP-OES). A quantificação do $\mathrm{Hg}$ foi realizada usando gerador de hidretos acoplado ao ICP. Para a obtenção do branco foi realizado o mesmo procedimento, porém sem a amostra.

\subsubsection{ANÁLISES MICROBIOLÓGICAS}

\subsubsection{Staphylococcus coagulase positiva}

A contagem de $S$. aureus foi realizada de acordo com Brasil (2003). Pesou-se, assepticamente, $25 \mathrm{~g}$ de camarão sete-barbas in natura, adicionou-se $225 \mathrm{~mL}$ de solução salina peptonada $0,1 \%$, homogeneizou-se por aproximadamente 60 segundos em "stomacher", obtendo-se a diluição $10^{-1}$. A partir da diluição inicial $10^{-1}$ efetuaram-se as demais diluições e então, realizou-se a inoculação de $0,1 \mathrm{~mL}$ de cada diluição selecionada sobre a superfície seca do ágar Baird-Parker. Com o auxílio de alça de Drigalski espalhou-se o inóculo cuidadosamente por toda a superfície do meio, em placas, até sua completa absorção. Foram realizadas duplicatas de cada diluição. As placas foram invertidas e incubadas a $36 \pm 1^{\circ} \mathrm{C}$ por 30 a 48 horas. Selecionaram-se as placas que continham entre 20 e 200 colônias, fez-se a contagem 
das colônias típicas (T) e atípicas (A), selecionando 3 a 5 colônias de cada tipo (T) e/ou (A). Semeou-se cada uma das colônias selecionadas em tubos contendo BHI e incubou-se a $36 \pm 1^{\circ} \mathrm{C}$, por 24 horas. Para o teste de confirmação transferiu-se $0,2 \mathrm{~mL}$ desta cultura para tubos estéreis e adicionou-se 0,5 mL de Coagulo Plasma - EDTA, misturou-se com movimentos de rotação suaves e incubou-os a 35-37 $\mathrm{C}$, durante 6 horas. Após este período, os tubos que apresentaram a formação de coágulos foram considerados positivos. Para a obtenção do número final de UFC.g ${ }^{-1}$ utilizou-se a seguinte fórmula:

\section{UFC. $g^{-1}=n \times d \times 10 \times p$}

Onde; $\mathbf{n}=$ número de colônias típicas nas placas do ágar Baird-Parker; $\mathbf{d}=$ diluição inoculada na referida placa (por exemplo; na diluição $10^{-3}=1000$ ); $\mathbf{1 0}=$ refere-se a quantidade de inóculo utilizado na placa do ágar Baird-Parker (neste estudo $0,1 \mathrm{~mL}) ; \mathbf{p}=$ porcentagem do total de colônias testadas que apresentaram coagulase positiva.

\subsubsection{Salmonella $\mathrm{sp}$}

Para a pesquisa de Salmonella foram utilizadas $25 \mathrm{~g}$ de camarão in natura adicionadas de $225 \mathrm{~mL}$ de solução salina peptonada $1 \%$ tamponada. Homogeneizouse por aproximadamente 60 segundos em "stomacher" e deixou por 1 hora em temperatura ambiente. Após o pré-enriquecimento fez-se a inoculação em meios seletivos (caldos Rappaport Vassiliadis, selenito cistina e tetrationato). A partir dos caldos de enriquecimento seletivo, foram repicadas sobre a superfície de placas, previamente secas, estriando-as de forma a se obter colônias isoladas em cada um dos meios sólidos seletivos. Dessa forma, foram obtidas 3 placas de BPLS, originárias dos caldos Rappaport Vassiliadis, caldo selenito cistina e caldo 
tetrationato, respectivamente. Todas as placas foram incubadas invertidas a $36 \pm 1^{\circ} \mathrm{C}$, por 18 a 24 horas. Selecionou-se de 3 a 10 colônias suspeitas por amostra e estas foram repicadas em ágar não seletivo e incubadas a $36 \pm 1^{\circ} \mathrm{C}$, por 18 a 24 horas, para verificar sua pureza, seguindo-se com as provas bioquímicas. O resultado foi considerado positivo para Salmonella quando as culturas apresentavam reações típicas nas provas bioquímicas e reação sorológica positiva frente ao anti-soro polivalente "O”, conforme exposto em Brasil (2003).

\subsubsection{Coliformes totais e termotolerantes}

Para a contagem de coliformes totais pesou-se, assepticamente, $25 \mathrm{~g}$ de camarão sete-barbas in natura, aos quais foram adicionados $225 \mathrm{~mL}$ de solução salina peptonada $0,1 \%$. Homogeneizou-se por aproximadamente 60 segundos em "stomacher", obtendo-se a diluição $10^{-1}$. A partir desta foram obtidas as demais diluições, que foram inoculadas em ágar cristal violeta vermelho neutro bile (VRBA) e incubadas a $36 \pm 1^{\circ} \mathrm{C}$, por 24 a 48 horas, para posterior contagem das colônias suspeitas. A presença de coliformes totais foi confirmada pela formação de gás (mínimo 1/10 do volume total do tubo de Durhan) ou efervescência quando agitado gentilmente. O resultado obtido para cada colônia, bem como, a diluição utilizada foram anotados. A leitura foi realizada após 24 horas de incubação, quando foram considerados válidos apenas os resultados positivos. Os tubos que apresentarem resultado negativo eram incubados por mais 24 horas.

A contagem dos coliformes termotolerantes foi realizada a partir da inoculação das culturas suspeitas de coliformes termotolerantes em tubos contendo caldo EC ( $\left.45^{\circ} \mathrm{C}\right)$ em banho maria com agitação, por 24 a 48 horas. A presença de coliformes termotolerantes foi confirmada pela formação de gás (mínimo 1/10 do volume total do tubo de Durhan) ou efervescência quando agitado gentilmente. O resultado obtido para cada colônia, bem como, a diluição utilizada foram anotados. A leitura foi realizada após 24 horas de incubação, quando foram considerados os 
resultados positivos. Os tubos que apresentarem resultado negativo eram incubados por mais 24 horas (BRASIL, 2003).

\subsubsection{Clostridium sulfito redutores}

A pesquisa para clostrídios sulfito redutores foi realizada em 7 das amostras de camarão sete-barbas e realizada de acordo com o Compendium of Methods for the Microbiological Examination of Foods (APHA), segundo Labbe (2001). Utilizou-se 25 g de camarão in natura, pesadas assepticamente e acrescidas de $225 \mathrm{~mL}$ de solução salina peptonada estéril (SSP 0,1\%), obtendo-se a diluição 1:10. A partir desta diluição foram realizadas mais três diluições seriadas a base 10 até 1:10.000 $\left(10^{-1}\right.$ a $\left.10^{-4}\right)$, totalizando quatro diluições da amostra. Foram inoculados $1 \mathrm{~mL}$ de cada diluição em tubos de ensaio com ágar sulfito polimixina sulfadiazina (SPS) fundido a $\sim 55^{\circ} \mathrm{C}$; realizou-se banho com gelo para solidificar o meio fundido, a retirada de oxigênio e posterior incubação a $45^{\circ} \mathrm{C} / 24$ horas. As colônias pretas características, passaram pelo teste confirmativo para Clostridium perfringens, coloração de Gram - bastonetes Gram positivos e os resultados foram obtidos pelo método de contagem direta, expresso em UFC. $\mathrm{g}^{-1}$ ( $\mathrm{n}^{\mathrm{o}}$ de colônias X maior diluição).

\subsubsection{ANÁLISE SENSORIAL}

Todas as sessões de avaliação sensorial foram realizadas em sala específica, com a área de preparação das amostras fisicamente separada da área de avaliação, equipada com ar condicionado e gabinetes para provas individuais com lâmpada fluorescente, de luz branca. Para o teste de aceitação sensorial foi utilizado um painel de 20 consumidores, composto de homens e mulheres de 20 a 60 anos, que avaliaram 
amostras compostas por 5-7 camarões in natura inteiros, lavados rapidamente em água potável corrente. Utilizou-se uma escala hedônica verbal de 7 pontos (Anexo 3), variando de 0 a 6 ( 0 - não gosto muito; 3 - não gosto nem desgosto e 6 - gosto muito), adaptado ao proposto por Meilgaard et al. (1999). A avaliação sensorial dos camarões incluiu os seguintes parâmetros: aparência, coloração, odor e textura (na mão). O painel foi questionado ao final de cada avaliação quanto à intenção de compra do produto apresentado.

\subsubsection{ANÁLISE ESTATÍSTICA}

Os dados obtidos foram tabulados em planilhas Excell, analisados pelo pacote estatístico STATA 8.0 (StatSoft Inc., USA) e expressos como média e desvio padrão. Foram realizadas correlações entre os valores médios dos distintos parâmetros estudados e valores de $\alpha=0,05$ ( $\mathrm{p}<0,05$ ) foram considerados significativos. (GONÇALVES et al., 2007). 


\subsection{RESULTADOS E DISCUSSÃO}

\subsubsection{LEVANTAMENTO DOS PRINCIPAIS PONTOS DE DESEMBARQUE DO CAMARÃO Xiphopenaeus kroyeri NO ESTADO DE SÃO PAULO E DEFINIÇÃO DOS PONTOS DE COLETA}

A pesca artesanal do camarão sete-barbas, denominada "pesca de sol a sol", na qual os pescadores saem para a pesca e retornam no mesmo dia, é realizada em grande escala no litoral brasileiro, apresentando significativa importância econômica, histórica, social e cultural. A pesca deste camarão é considerada a de maior interesse econômico nas regiões Sudeste-Sul do país, sendo o segundo recurso pesqueiro mais explorado nestas regiões (BRANCO, 2005).

Segundo o Informe da Produção Pesqueira Marinha e Estuarina do Estado de São Paulo (INSTITUTO DE PESCA, 2011), a região Metropolitana da Baixada Santista é a principal produtora deste camarão no Estado de São Paulo. A região é composta por 9 municípios, a saber, Peruíbe, Itanhaém, Mongaguá, Praia Grande, São Vicente, Santos, Guarujá, Bertioga e Cubatão (Figura 7). Dentre eles, apenas Cubatão não realiza a pesca do camarão sete-barbas.

Os principais desembarques de camarão sete-barbas da região metropolitana da Baixada Santista, em produção, encontram-se localizados nos municípios de Bertioga, Santos, Guarujá, Itanhaém e Peruíbe, como apresentado na Tabela 1.

Tabela 1. Principais espécies de pescado (t) descarregado na Baixada Santista, SP., por município, no período de janeiro a junho 2011.

\begin{tabular}{|c|c|c|c|c|c|c|c|}
\hline Categorias de Pescado & Bertioga & Santos / Guarujá & São Vicente & Praia Grande & Mongaguá & Itanhaém & Peruíbe \\
\hline Corvina & 9,2 & 710,5 & 0,2 & 4,1 & 2,2 & 0,2 & 1,1 \\
\hline Camarão-sete-barbas & 75,9 & 490,4 & 1,7 & 0,1 & 1,0 & 7,7 & 13,2 \\
\hline Sardinha-verdadeira & - & 932,4 & - & - & - & - & - \\
\hline Goete & - & 495,5 & 0,0 & 0,0 & 0,2 & 0,0 & 0,0 \\
\hline Pescada-foguete & 5,1 & 109,7 & - & 6,4 & 5,0 & 0,8 & 0,9 \\
\hline Betara & 0,1 & 184,5 & 0,1 & 0,8 & 0,7 & 0,0 & 2,0 \\
\hline
\end{tabular}

Fonte: Instituto de Pesca (2011) 
Com base neste levantamento e no número de embarcações envolvidas na pesca do camarão, nos distintos locais de desembarque destes municípios, foram definidos os pontos de coleta a serem amostrados para a caracterização da qualidade do camarão sete-barbas desembarcado na Baixada Santista, a saber: Bertioga (1), Santos (1), Guarujá (2), Itanhaém (2), e Peruíbe (1). Devido a expressiva maior produção dos municípios de Santos e Guarujá, um maior número de amostragens foram realizadas nestes municípios, no total de 20 coletas.

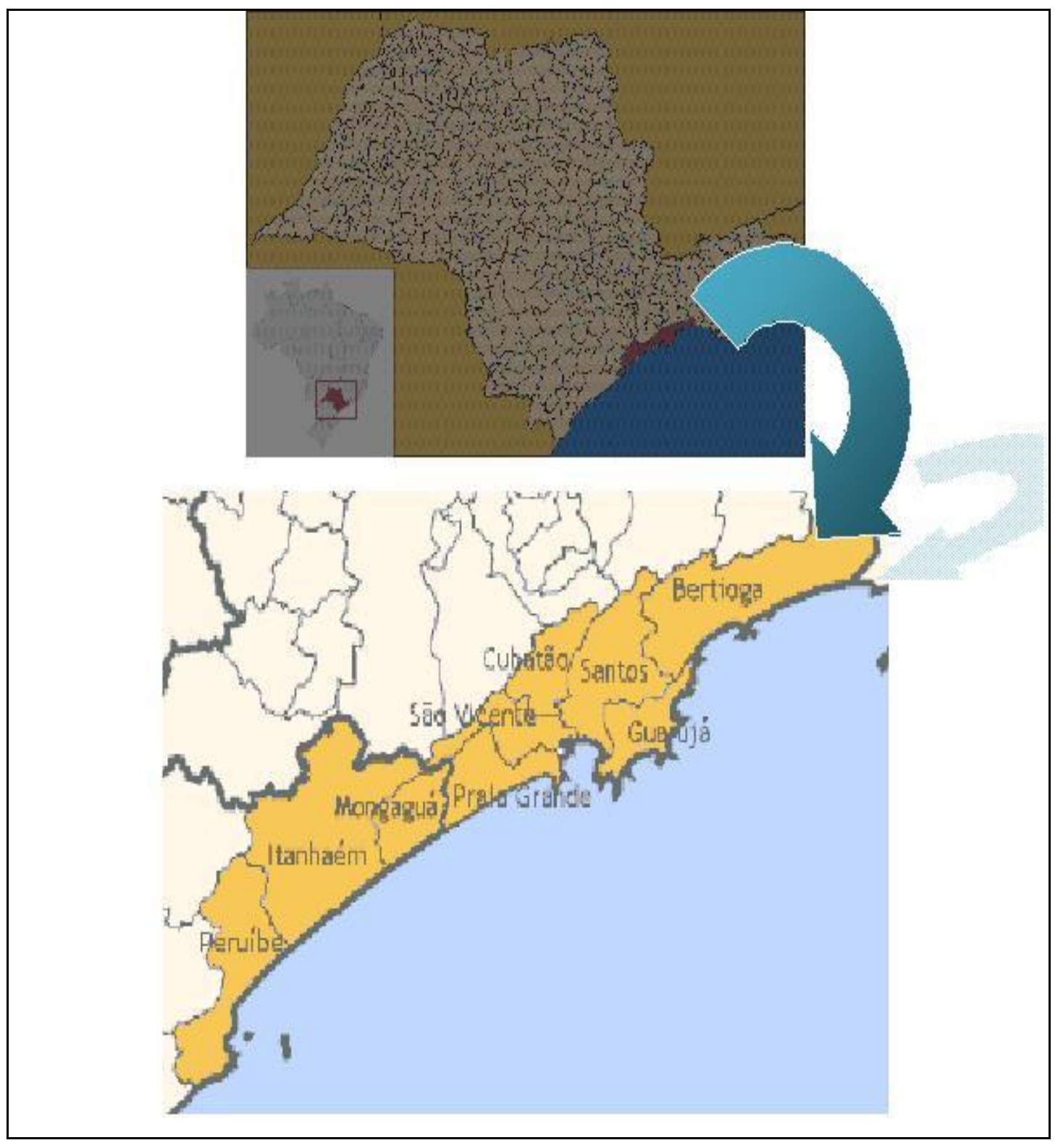

Figura 7. Mapa do Estado de São Paulo e abaixo dos municípios da Baixada Santista. 
Na Figura 8 é possível observar a distribuição das amostragens (\%) em função dos municípios e o maior número (55\%) referente aos desembarques dos municípios de Guarujá e Santos, a saber, na praia do Perequê, no Rio do Meio e na altura da Rua do Peixe. A Figura 9 mostra que a pesca de "sol a sol" predominou entre as amostragens (80\%). A pesca em Baleeira, caracterizada por ficar vários dias ao mar, no presente estudo esteve representada por embarcações que permaneceram 3 e 10 dias no mar.

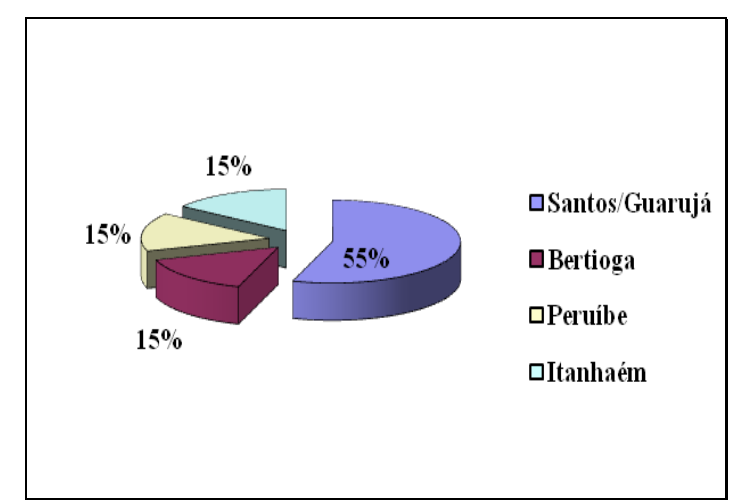

Figura 8. Amostras por município (\%).

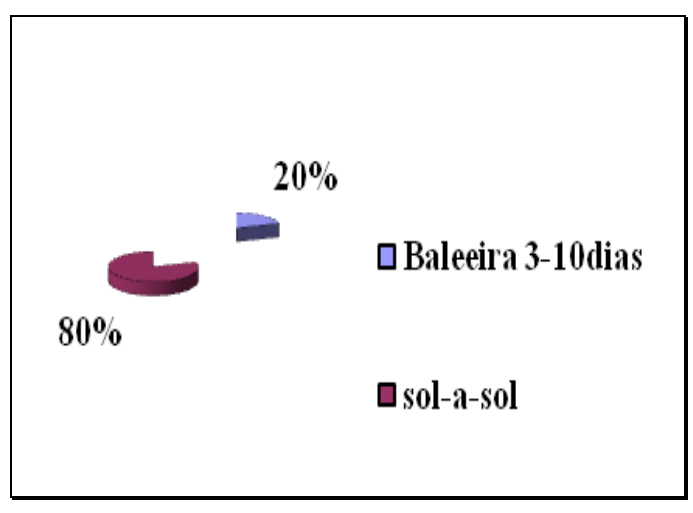

Figura 9. Amostras por tipo de pesca (\%).

\subsubsection{ANÁLISES FÍSICAS, FÍSICO QUÍMICA E QUÍMICAS}

\subsubsection{Biometria}

No geral, as amostragens apresentaram-se bastante heterogêneas quanto ao tamanho (Tabela 2), algumas porque não eram classificadas a bordo e outras, devido 
a escassez da espécie no período; o que levou os pescadores a aproveitarem ao máximo a pesca comercializando até mesmo exemplares diminutos. A redução da produção de sete-barbas no período foi atribuída, por alguns profissionais da pesca, à elevada quantidade de lixo presente na costa e ainda ao aparecimento de outras espécies, como o camarão Artemisia longinaris.

Os resultados da biometria indicam que os camarões sete-barbas desembarcados na Baixada Santista apresentaram em média $8,18 \mathrm{~cm}$ de comprimento, tendo variado de 3,80 a $12,60 \mathrm{~cm}$. Houve predominância de camarões na faixa de 9 a $13 \mathrm{~cm}$ de comprimento, que representaram $45 \%$ dos camarões mensurados (Figura 10).

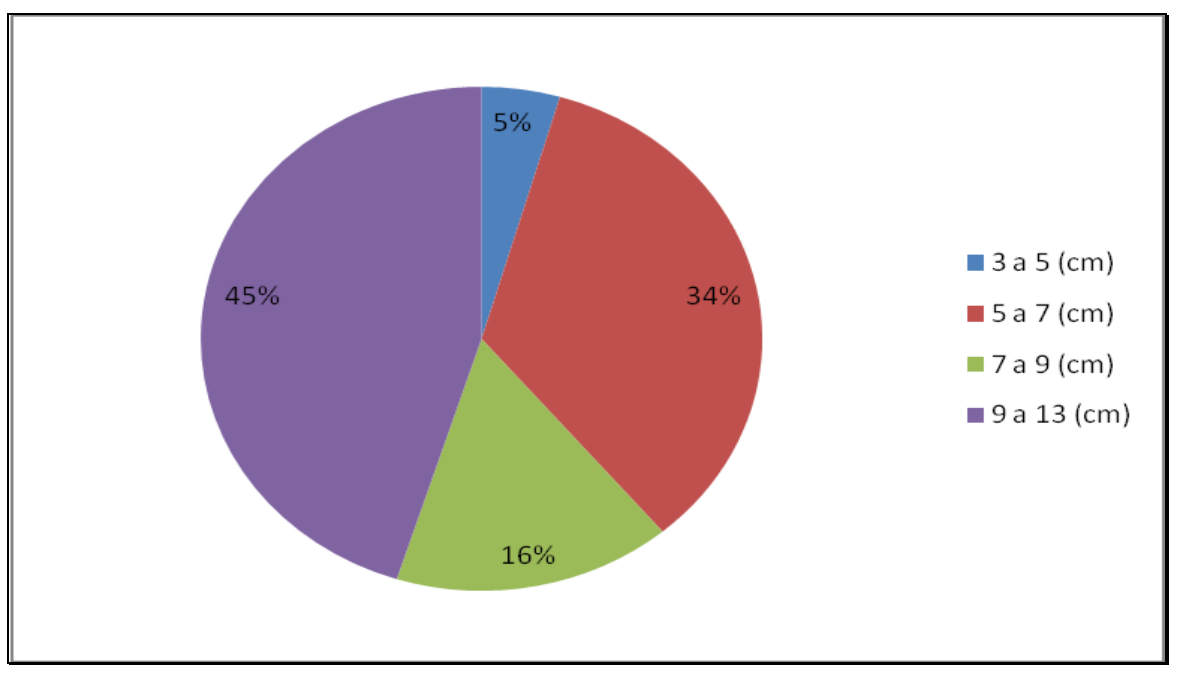

Figura 10. Camarão sete-barbas colhidos na Baixada Santista, SP., por faixas de comprimento (\%).

O tamanho dos camarões exerce grande influência sobre a sua qualidade. Camarões menores desenvolvem melanose mais precocemente, deterioram-se mais rapidamente e a falta de classificação pelo tamanho, bem como, por espécie incorre 
em uma menor durabilidade do lote. A presença de exemplares de menor tamanho acelera o processo de decomposição, comprometendo o lote, fato também evidenciado neste trabalho, uma vez que a regressão linear das medidas de tamanho dos camarões $(\mathrm{cm})$ pelas mensurações de BNVT resultou no coeficiente de correlação $r=-0,79(p<0,05)$, ou seja, os maiores valores de BNVT relacionados aos menores exemplares de camarão sete-barbas (Figura 11).

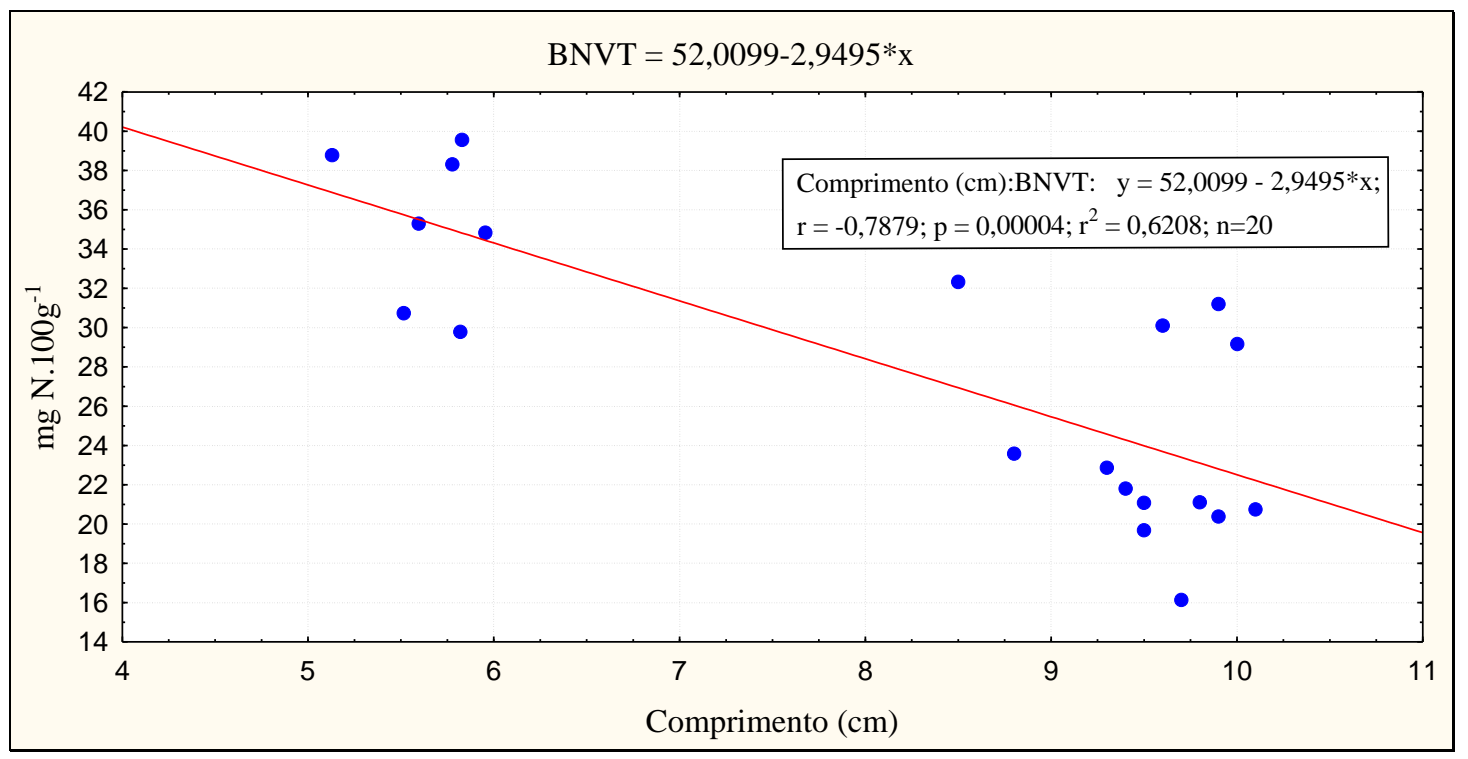

Figura 11. Dispersão dos valores médios de BNVT $\left(\mathrm{mg} \mathrm{N} \cdot 100 \mathrm{~g}^{-1}\right)$ pelo comprimento $(\mathrm{cm})$.

O tamanho dos camarões também apresentou correlação com a aceitação sensorial global do produto in natura $(\mathrm{r}=0,70 ; \mathrm{p}<0,05)$, indicando que os camarões maiores obtiveram melhor aceitação pelos julgadores na avaliação sensorial (Tabelas 2 e 3$)$. 
Tabela 2. Comprimento médio $(\mathrm{cm})$ de camarões sete-barbas (X. kroyeri) desembarcados na região metropolitana da Baixada Santista, de outubro/2011 à fevereiro/2012.

\begin{tabular}{|c|c|c|c|c|}
\hline Amostras & Comprimento médio* & Desvio Padrão & Máximo & Mínimo \\
\hline 1 & 5,78 & 0,75 & 7,10 & 4,00 \\
\hline 2 & 5,83 & 0,69 & 7,00 & 4,80 \\
\hline 3 & 5,60 & 0,58 & 6,40 & 4,30 \\
\hline 4 & 5,13 & 0,83 & 6,50 & 3,80 \\
\hline 5 & 5,96 & 0,66 & 7,50 & 5,00 \\
\hline 6 & 5,82 & 0,57 & 6,50 & 4,50 \\
\hline 7 & 5,52 & 0,60 & 6,80 & 4,50 \\
\hline 9 & 8,5 & 1,1 & 10,2 & 6,4 \\
\hline 10 & 10 & 1,1 & 11,6 & 7,6 \\
\hline 11 & 9,6 & 1,2 & 11,2 & 7,2 \\
\hline 12 & 9,9 & 0,7 & 11,1 & 8,7 \\
\hline 13 & 9,5 & 1,2 & 12,2 & 7,4 \\
\hline 14 & 9,5 & 1,1 & 12 & 8,2 \\
\hline 15 & 9,7 & 1,1 & 12,6 & 8,2 \\
\hline 16 & 9,9 & 0,9 & 11,6 & 8,1 \\
\hline 17 & 9,3 & 0,8 & 11 & 8 \\
\hline 18 & 9,4 & 0,8 & 11,1 & 7,9 \\
\hline 19 & 8,8 & 1,3 & 11,6 & 7,3 \\
\hline 20 & 10,1 & 0,7 & 11,4 & 9 \\
\hline 21 & 9,8 & 1,0 & 11,7 & 8,3 \\
\hline
\end{tabular}

*Valor médio de $\mathrm{n}=20$ 


\subsubsection{Valor de $\mathrm{pH}$}

Os valores de $\mathrm{pH}$ dos camarões apresentaram-se sempre elevados, em média 7,61 \pm 0,03, tendo variado de 7,37 a 8,14 (Tabela 3). Segundo o Regulamento de Inspeção Industrial e Sanitária dos Produtos de Origem Animal (BRASIL, 1952), o pescado é considerado adequado para o consumo quando o $\mathrm{pH}$ da carne externa é inferior a 6,8 e o da carne interna a 6,5. Portanto, se levarmos em conta a legilação nacional vigente todos os lotes analisados estariam inconformes. Entretanto, as coletas foram realizadas no primeiro elo da cadeia produtiva, onde supostamente encontramos o produto em seu estado pleno de frescor.

Considerando todos os cuidados tomados durante a coleta, acondicionamento e transporte até o laboratório, duas hipóteses podem ser viáveis, que os padrões legislados para pH não estão adequados para a espécie em questão e/ou que as práticas a bordo das embarcações são ineficazes à preservação da qualidade da referida espécie.

Diversos estudos indicam deficiência na prática de manipulação a bordo das embarcações pesqueiras (THAMPURAN; GOPAKUMAR, 1990; MOURA et al., 2003; YOKOYAMA, 2007; MACHADO et al., 2010) e até mesmo na presente pesquisa foi pontuada uma situação onde não havia presença de gelo na embarcação. Entretanto, $80 \%$ das embarcações praticavam pesca de "sol a sol" e muitas utilizavam gelo a bordo e desembarcaram camarões com ótima aparência, indicando que estes padrões propostos pela legislação nacional para o pH não condizem com a qualidade para consumo do camarão X.kroyeri.

Apesar das alterações bioquímicas, como o aumento do BNVT devido à degradação por microrganismos e ação de enzimas tissulares, promoverem a elevação do pH muscular, Yokoyama (2007) também obteve valores elevados de pH 
para camarões $X$.kroyeri com apenas 1 dia de armazenamento sob refrigeração $(7,63$ para camarões inteiros e 7,77 para camarões descascados).

Gonçalves e Junior (2009) obtiveram pH 9,10 e 9,27, no tempo zero do armazenamento sob congelamento, para a mesma espécie. Estes últimos autores demonstraram a redução do $\mathrm{pH}$ muscular durante o armazenamento sob congelamento do produto glaciado e que, o glazeamento e o armazenamento sob congelamento deste produto pesqueiro é alternativa para prolongar sua vida útil.

Tabela 3. Valores médios de BNVT, pH, TBARS, residual de SO2, firmeza, mercúrio e aceitação sensorial de camarões X.kroyeri desembarcados na região Metropolitana da Baixada Santista, de outubro de 2011a fevereiro de 2012.

\begin{tabular}{|c|c|c|c|c|c|c|c|}
\hline AMOSTRAS & pH & $\begin{array}{c}\text { BNVT } \\
\left(\mathrm{mg} \mathrm{N} .100 \mathrm{~g}^{-1}\right)\end{array}$ & $\begin{array}{c}\text { TBARS } \\
\left(\mathrm{mg} \mathrm{AM.} \mathrm{Kg}^{-1}\right)\end{array}$ & $\begin{array}{c}\mathrm{SO}^{2} \\
\left(\mathrm{mg} \cdot \mathrm{Kg}^{-1}\right)\end{array}$ & $\begin{array}{l}\text { Firmeza } \\
\text { (N) }\end{array}$ & $\begin{array}{c}\mathrm{Hg} \\
\left(\mathrm{mg} \cdot \mathrm{Kg}^{-1}\right)\end{array}$ & $\begin{array}{l}\text { Aceitação } \\
\text { sensorial* }\end{array}$ \\
\hline $1^{*}$ & $8,14 \pm 0,04$ & $38,32 \pm 0,55$ & $14,43 \pm 0,03$ & 332.8 & $3,64 \pm 1,04$ & $<0,05$ & 2 \\
\hline $3^{*}$ & $7,95 \pm 0,01$ & $35,31 \pm 0,00$ & $13,68 \pm 0,02$ & 362.40 & $5,97 \pm 1,34$ & $<0,05$ & 1 \\
\hline 4 & $7,67 \pm 0,04$ & $38,79 \pm 0,27$ & $4,22 \pm 0,00$ & $<10$ & $5,90 \pm 1,64$ & $<0,05$ & 2 \\
\hline 6 & $7,52 \pm 0,07$ & $29,79 \pm 1,09$ & $2,71 \pm 0,00$ & $<10$ & $6,99 \pm 1,90$ & $<0,05$ & 4 \\
\hline $7 *$ & $7,55 \pm 0,03$ & $30,74 \pm 0,55$ & $12,18 \pm 0,00$ & 42,03 & $6,13 \pm 1,73$ & $<0,05$ & 5 \\
\hline 9 & $7,56 \pm 0,02$ & $32,32 \pm 0,55$ & $14,00 \pm 0,01$ & $<10$ & $6,30 \pm 1,74$ & $<0,05$ & 6 \\
\hline 10 & $7,56 \pm 0,03$ & $29,16 \pm 0,00$ & $8,43 \pm 0,01$ & 57,47 & $7,26 \pm 1,17$ & $<0,05$ & 6 \\
\hline 11 & $7,53 \pm 0,02$ & $30,11 \pm 0,47$ & $6,07 \pm 0,01$ & $<10$ & $7,54 \pm 1,49$ & $<0,05$ & 6 \\
\hline 15 & $7,61 \pm 0,03$ & $16,14 \pm 1,23$ & $6,00 \pm 0,00$ & $<10$ & $7,07 \pm 2,31$ & $<0,05$ & 6 \\
\hline 16 & $7,56 \pm 0,05$ & $20,39 \pm 0,61$ & $25,07 \pm 0,01$ & $<10$ & $7,79 \pm 1,78$ & $<0,05$ & 6 \\
\hline 17 & $7,46 \pm 0,03$ & $22,87 \pm 0,53$ & $18,12 \pm 0,01$ & $<10$ & $6,76 \pm 1,16$ & $<0,05$ & 2 \\
\hline 18 & $7,43 \pm 0,03$ & $21,81 \pm 0,00$ & $6,52 \pm 0,01$ & 11,21 & $6,06 \pm 1,19$ & $<0,05$ & 6 \\
\hline 19 & $7,59 \pm 0,03$ & $23,58 \pm 0,61$ & $9,17 \pm 0,01$ & $<10$ & $5,65 \pm 1,44$ & $<0,05$ & 5 \\
\hline 20 & $7,44 \pm 0,03$ & $20,75 \pm 1,06$ & $14,71 \pm 0,01$ & $<10$ & $7,41 \pm 1,18$ & $<0,05$ & 6 \\
\hline 21 & $7,37 \pm 0,02$ & $21,10 \pm 1,23$ & $23,25 \pm 0,01$ & $<10$ & $6,56 \pm 1,02$ & $<0,05$ & 6 \\
\hline
\end{tabular}

BNVT = Bases Nitrogenadas Voláteis Totais; TBARS = Substâncias reativas ao Ácido Tiobarbitúrico; Escala de aceitação sensorial $(0=$ Não gosto muito; $1=$ Não gosto moderadamente; 2 = Não gosto ligeiramente; 3 = Não gosto nem desgosto; 4= Gosto ligeiramente; $5=$ Gosto moderadamente e $6=$ Gosto muito, para $n=20$ ).

*Amostras oriundas de pesca de longa duração (3 e 10 dias) 
Mendes et al. (2005) verificaram que amostras de camarão Parapenaeus longirostris de qualidade aceitável apresentaram $\mathrm{pH} \leq 7,9$. No presente estudo amostras na faixa de $\mathrm{pH}$ entre 7,4 e 7,6 foram avaliadas sensorialmente como "muito bom" - escore 6, reforçando a necessidade de revisão dos padrões atualmente propostos para os valores de pH do músculo para a espécie em questão.

\subsubsection{Bases nitrogenadas voláteis}

Apenas 47,62\% das amostras de camarão sete-barbas estudadas apresentaram valores de BNVT (Tabela 3) dentro dos limites preconizados pela legislação nacional para qualificação do pescado para o consumo, cujo limite é de $30 \mathrm{mg} \mathrm{N} .100 \mathrm{~g}^{-1}$ de pescado (BRASIL, 1952). O valor médio obtido foi $27,88 \pm 7,27 \mathrm{mg} \mathrm{N} .100 \mathrm{~g}^{-1}$ da porção cárnea, tendo variado de 16,14 a $39,58 \mathrm{mg} \mathrm{N} 100 \mathrm{~g}^{-1}$ entre as amostras. Camarões sete-barbas com até $33 \mathrm{mg} \mathrm{N} .100 \mathrm{~g}^{-1}$ de músculo apresentaram aceitação sensorial "gosto muito".

Os maiores valores de $\mathrm{pH}$ e BNVT, encontrados na presente pesquisa, referem-se as amostras provenientes da pesca em "baleeira", ou seja, pescado embarcado por vários dias, indicando que o período do pescado embarcado e determinante na sua qualidade. Os valores médios para BNVT e pH dos camarões provenientes de pesca de "sol a sol" e "baleeira" foram 26,14mg N. $100 \mathrm{~g}^{-1} ; 7,5 \mathrm{e}$ $37,73 \mathrm{mg}$ N. $100 \mathrm{~g}^{-1} ; 8,1$, respectivamente.

A TMA tem limites estipulados pela legislação nacional de até $4 \mathrm{mg}$ N. $100 \mathrm{~g}^{-}$ 1, mas não foi detectada nas amostras pesquisadas. De acordo com Howgate (2010), a TMA é formada em pescado armazenado em gelo pela redução do óxido de trimetilamina (TMAO) por bactérias predominantemente do gênero Shewanella. Em 
peixes provenientes de águas quentes a deterioração é causada, principalmente, por bactérias do gênero Pseudomonas e a amônia, em vez de TMA, é então produzida (GRAM; HUSS, 1996; CHINIVASAGAM et al. 1998).

Consequentemente, há apenas pequenos aumentos, quando há, nas concentrações de TMA durante a deterioração em espécies capturadas em águas quentes, embora possa ter grandes aumentos nas concentrações de BNVT devido a formação de amônia. Fato que pode explicar a ausência da TMA nos camarões estudados, apesar dos altos valores de BNVT.

Chang et al. (1983) apontaram a inadequação da determinação da TMA como parâmetro de qualidade para os camarões Penaeus duorarum e P. setiferus, uma vez que estes detectaram quantidades mínimas de TMA em camarões sensorialmente comprometidos.

Farinha (2006) relatou que os valores de BNVT podem indicar o frescor para o camarão rosa; apontando valores $\leq 30 \mathrm{mg} \mathrm{N}$. $100 \mathrm{~g}^{-1}$ de amostra como indicadora do frescor; 40 a $45 \mathrm{mg} \mathrm{N}$. $100 \mathrm{~g}^{-1}$ para aceitável e valores $>45 \mathrm{mg} \mathrm{N} .100 \mathrm{~g}^{-1}$ como não adequado para o consumo.

Botta (1994), Mendes et al. (2005) e Mendes (2006) relacionaram valores de BNVT $\leq 20 \mathrm{mg} \mathrm{N} / 100 \mathrm{~g}$ com o frescor do camarão; valor $\leq 30 \mathrm{mg} \mathrm{N} / 100 \mathrm{~g}$ de amostra como aceitável e > $40 \mathrm{mg}$ N/100 g não adequado para o consumo. Considerando estes valores indicados pelos diferentes autores, também para o camarão sete-barbas, teríamos que todas as amostras estudadas estão adequadas ao consumo.

Para Sarnoski (2007) a concentração de BNVT é o melhor indicador da qualidade de peixes, mas não de moluscos e crustáceos. Yokoyama (2007) obteve valores medianos a elevados de BNVT para camarões sete-barbas tratados com antimelanóticos, 24 horas após o desembarque e os resultados da autora sempre estiveram de acordo com os limites estipulados pela legislação nacional. 
Yokoyama (2007) também pesquisou a vida útil de camarões sete-barbas inteiros e descabeçados, obtendo valores de BNVT inferiores ao estipulado pelo RIISPOA até o $12^{\circ}$ dia de armazenamento sob refrigeração, indicando que os camarões sete-barbas na presente pesquisa, referentes a região metropolitana da Baixada Santista, apresentariam baixa qualidade já no primeiro elo da cadeia produtiva.

Considerando as diferenças analíticas entre os estudos de Yokoyama (2007) e a atual pesquisa, os valores superiores nas determinações de BNVT desta pesquisa podem estar atribuídos ainda, as diferentes conduções do ensaio analítico descrito em Brasil (1981), bem como, aos diferentes locais de captura.

Segundo Howgate (2010), o conteúdo de BNVT e de metilaminas individualmente, em especial a TMA, tem longa história de uso como medida de deterioração de pescado. Para o autor as variações nas medições de TMA e BNVT são grandes e adicionalmente, existem variações entre lotes devido aos fatores biológicos. Concluindo que a determinação dos valores de TMA e BNVT são índices ineficazes para aferição do frescor no controle de qualidade comercial ou oficial.

Considerando que a determinação das BNVT é um método simples e, portanto, amplamente utilizado para avaliar a qualidade do pescado e produtos derivados para o consumo, é importante avançar na harmonização das metodologias utilizadas para a obtenção de resultados comparáveis e proposição de padrões mais adequados, uma vez que o método analítico utilizado pode interferir na quantificação das bases nitrogenadas voláteis totais.

Os controles previstos no Regulamento (CE) $n^{\circ}$ 853/ 2004, para evitar a colocação no mercado de produtos da pesca impróprios para o consumo humano também incluem a determinação das BNVT, no caso de dúvida, quanto a qualidade do produto. Segundo o Regulamento europeu, faz-se necessário estabelecer níveis de BNVT que não podem ser ultrapassados no caso de determinadas categorias de espécies, bem como, especificar os métodos de análise utilizados. O regulamento indica ainda, que os métodos de análise reconhecidos cientificamente devem ser 
utilizados na rotina, devendo-se especificar um método de referência para os casos de dúvidas quanto aos resultados ou litígio (UE, 2005).

Os resultados de BNVT para o camarão sete-barbas obtidos nesta pesquisa apresentaram correlação (r) com os valores de $\mathrm{pH}$, aceitação sensorial global do camarão sete-barbas in natura e com o seu tamanho ( $\mathrm{p} \leq 0,01)$, mostrando-se um parâmetro de aferição do frescor promissor para a espécie.

\subsubsection{Substâncias reativas ao ácido tiobarbitúrico}

A análise de TBARS utilizou como parâmetro de quantificação o (di)aldeído malônico (AM), um dos principais produtos da decomposição dos hidroperóxidos de ácidos graxos insaturados, cujo valor médio obtido foi $10,54 \pm 6,56 \mathrm{mg} \cdot \mathrm{Kg}^{-1}$, tendo variado de 2,50 a $26,93 \mathrm{mg}$. $\mathrm{Kg}^{-1}$, apesar do reduzido teor lipídico dos camarões ( $0,8 \%)$.

Às amostras provenientes de baleeiras, ou seja, dos embarques de longa duração sempre apresentaram valores muito elevados de TBARS (Tabela 3) e ainda, às amostras provenientes dos desembarques de Bertioga, Santos e Guarujá.

Hoyland e Taylor (1991) indicam a existência de correlação entre os valores de TBARS e a avaliação sensorial e Ke et al. (1982) apontam que o pescado com valores de TBARS acima de $1,5 \mathrm{mg}$. $\mathrm{Kg}^{-1}$ apresentam flavour a ranço.

No entanto, partindo-se de matrizes diferentes, não se pode atribuir notas sensoriais a determinados valores de TBARS, pois estes variam com o produto, em função da sua composição em ácidos graxos (OSAWA; DE FELÍCIO; GONÇALVES, 2005). 
A grande variabilidade dos valores obtidos para as TBARS no presente estudo, bem como, a ausência de correlação dos mesmos com os demais aspectos da qualidade investigados para o camarão sete-barbas, indicam que este parâmetro não deve ser utilizado para qualificar a espécie de forma isolada.

Apesar da determinação de TBARS ser o método mais utilizado na avaliação da oxidação lipídica em tecidos animais; por se tratar de uma determinação colorimétrica, pode não ser adequada para a análise dos camarões sete-barbas não tratados com sulfito, pois o processo de extração destas amostras com TCA resultou em extratos de coloração levemente salmão.

A coloração salmonada se deu, provavelmente, devido a presença de carotenóides, uma vez que, de acordo Ogawa et al., (2007), camarões sete-barbas apresentam astaxantina, $\beta$-caroteno-5,6-epóxido e astaceno em sua composição.

Os camarões tratados com sulfito, normalmente, resultaram em extratos mais límpidos e que, após a reação com o TBA a $100^{\circ} \mathrm{C}$, tornavam-se rosa como o esperado. Entretanto, para os camarões que não receberam sulfito, os extratos após reação do TBA com o AM tornavam-se rosa, mas com a influência dos carotenóides sobre a sua coloração, aproximando-se a cor salmão.

\subsubsection{Teor residual de dióxido de enxofre}

Os resultados obtidos para a região de estudo indicam que o limite residual de dióxido de enxofre $\left(\mathrm{SO}_{2}\right)$, em camarões provenientes de "baleeiras", apresentaram-se acima do limite permitido pela ANVISA, de $100 \mathrm{mg} \mathrm{Kg}^{-1}$ no pescado cru (BRASIL, 
1988). Enquanto a pesca de "sol a sol" proporcionou camarões com teores mínimos de dióxido de enxofre (Tabela 3).

Os valores superiores de $\mathrm{SO}_{2}$ para os camarões provenientes de "baleeiras" eram esperados, devido ao período mais extenso que os camarões permanecem embarcados e a limitada vida útil da espécie em questão, o que estimula o uso de subterfúgios para a preservação da sua qualidade, no caso os sulfitos.

No entanto, a utilização dos sulfitos em crustáceos deve atender aos limites estabelecidos e as boas práticas de manipulação (BPM) para a segurança do consumidor e do manipulador deste pescado.

O monitoramento de alimentos adicionados de sulfito já foi indicado pelo Codex Committee on Foods Additives and Contaminants (CCFAC), em 2006, tendo sido colocado na lista de prioridades de avaliação pelo Joint FAO/WHO Expert Committee on Food Additives (JECFA), devido aos riscos asssociados ao consumo destes produtos (WHO, 2009).

Por outro lado, a cor e aparência de um alimento são os primeiros aspectos avaliados pelo consumidor, fazendo da melanose o principal entrave da indústria camaroeira, uma vez que ocasiona importante perda comercial. Consequentemente, a prática do uso dos sulfitos, como preservativo é comum entre os profissionais da pesca e cultivo do camarão.

Frente a este fato, evidencia-se a necessidade de pesquisas quanto ao uso de conservantes em pescado, bem como, da capacitação dos profissionais da pesca em BPM, minimizando os riscos associados ao consumo deste crustáceo.

O não atendimento aos limites de segurança estabelecidos pelos produtos provenientes de balleiras indica que existe risco no consumo do camarão sete-barbas, proveniente deste tipo de pesca (de longa duração), principalmente, às pessoas asmáticas, imunodeprimidas, idosos e crianças. 
5.3.2.6 Determinação instrumental da cor

A determinação instrumental da cor, utilizando-se o sistema CIELab , espaço de cor mais completo especificado pela Comissão Internacional de Iluminação (Commission Internationale de l'éclairage, então das iniciais CIE), resultou nos valores médios de 15,42 \pm 3,75; $0,90 \pm 0,72$ e 8,27 $\pm 1,32$, para $L^{*} a^{*}$ e $b^{*}$, respectivamente, como apresentado na Figura 12.

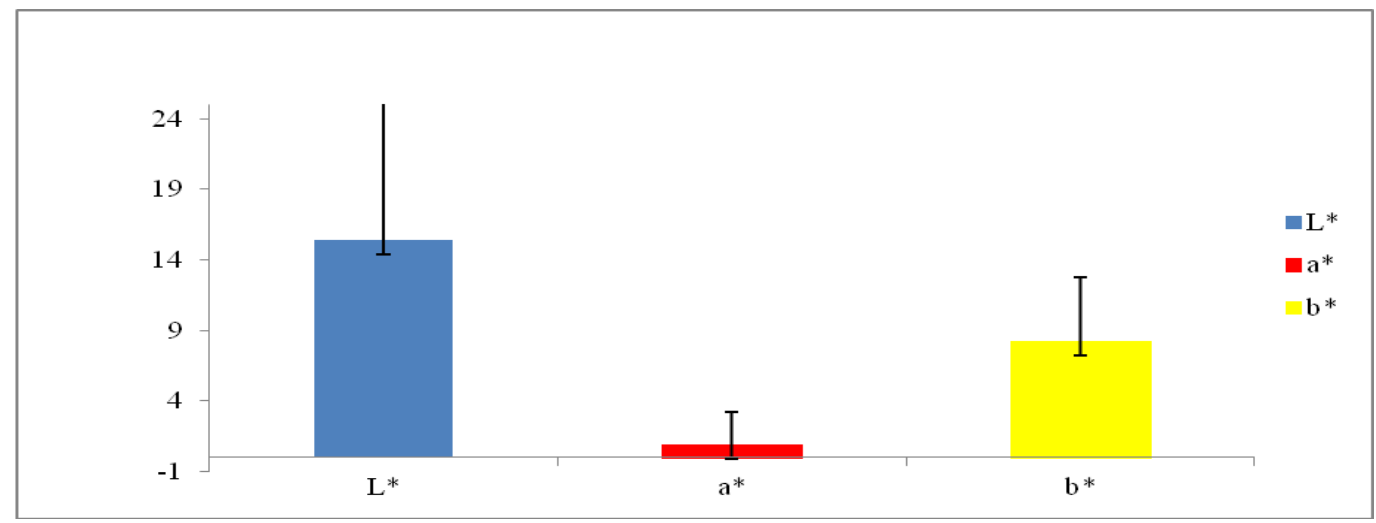

Figura 12. Coloração de camarões sete-barbas inteiros (CIELab system), valores médios de $L^{*} a^{*} b^{*}$.

Apesar da coloração dos camarões no presente estudo apresentar grande influencia sobre a aceitação sensorial dos mesmos, os valores obtidos pelo sistema CIELab foram muito variáveis e obtiveram um baixo coeficiente de correlação com a aceitação sensorial. Entretanto, os valores de $\mathrm{L}^{*} \mathrm{a}^{*} \mathrm{~b}^{*}$ e $\mathrm{C}^{*}$ apresentaram correlação positiva com os valores de BNVT e pH (Tabela 4). 
Tabela 4. Coeficiente de correlação da coloração de camarões sete-barbas, determinada pelo CIELab sistem, com os parâmetros sensoriais e físico e químico, $\mathrm{pH}$ e BNVT $(\mathrm{p}<0,01)$.

\begin{tabular}{lcccc}
\hline Cor & $\mathbf{L}^{*}$ & $\mathbf{a}^{*}$ & $\mathbf{b}^{*}$ & $\mathbf{C}^{*}$ \\
\hline Aceitação sensorial & $-0,61$ & $-0,55$ & $-0,64$ & $-0,62$ \\
pH & 0,65 & 0,87 & 0,76 & 0,79 \\
BNVT & 0,75 & 0,72 & 0,77 & 0,77 \\
\hline
\end{tabular}

Segundo Yokoyama (2007), quanto menor o valor de L* do camarão setebarbas mais avançado o desenvolvimento da melanose, tendo obtido valores de 33,1 a 40,3 para o camarão tratado com diferentes antimelanóticos.

Os valores médios obtidos para $\mathrm{L}^{*}, \mathrm{a}^{*}, \mathrm{~b}^{*}$ e $\mathrm{C}^{*}$ apresentaram elevada correlação com o uso de sulfito, $r=0,75 ; 0,91 ; 0,86$ e 0,87 ( $p<0,05)$, respectivamente. Indicando que os maiores valores para estes parâmetros estão associados aos camarões tratados com sulfito, ou seja, provenientes de "baleeiras" e que, no presente estudo tratam-se também das amostras com qualidade sensorial inferior, provavelmente devido aos vários dias de embarque.

Os valores de $\mathrm{L}^{*}$ superiores estão associados com o uso excessivo de sulfitos nos camarões provenientes da pesca em "baleleira" e não a perda de qualidade, uma vez que este parâmetro refere-se a luminosidade e esta é aumentada com o uso dos sulfitos (Figura 13).
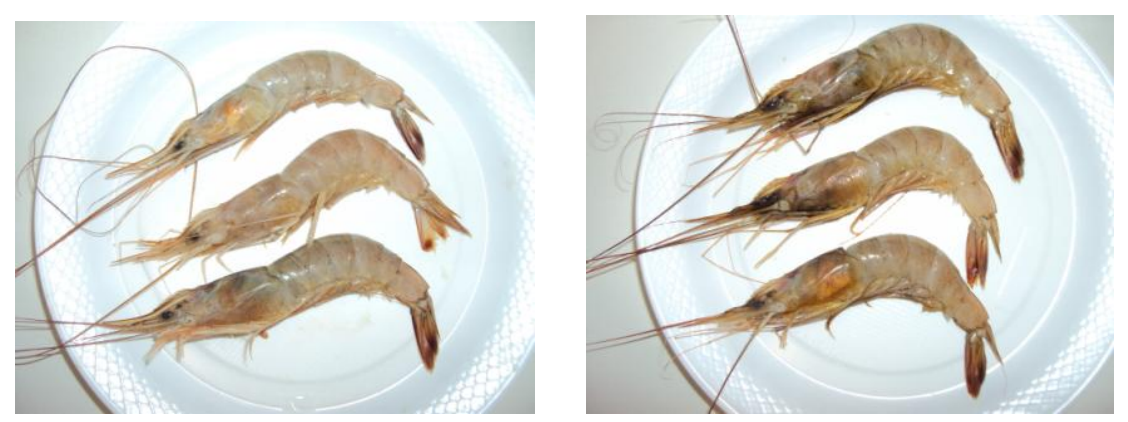

Figura 13. Camarões sete-barbas com 3 dias de vida útil, tratados com sulfito (esquerda) e sem sulfito (direita). 
Portanto, como discutido por Yokoyama (2007), a redução dos valores de L* do camarão sete-barbas está associada ao desenvolvimento da melanose, ou seja, a perda da qualidade sensorial.

Os menores valores de $\mathrm{L}^{*}$ no presente estudo, comparados aos obtidos por Yokoyama (2007), para a mesma espécie, pode ser justificado pelo não uso de sulfitos na maioria dos lotes de camarão aqui amostrados. Pois como pontuado, os camarões com sulfito apresentam-se mais claros, ou seja com L* (luminosidade) superior.

Para $C^{*}$ o valor médio encontrado foi de 8,42 $\pm 4,56$, tendo variado de 3,99 a 18,12. Se considerarmos apenas as amostras que receberam avaliação sensorial "muito bom", ou seja, 55\% das amostras, temos que a coloração adequada para melhor aceitação da espécie em estudo encontra-se nas faixas de 3,99 a 6,82 para C*; 5,37 a 12,08 para $L^{*} ;-0,43$ a 0,29 para a* e 3,98 a 6,82 para b*, seguindo-se o mesmo procedimeto metodológico.

Os padrões de coloração para a espécie parecem promissores, mas devem ser mais estudados, frente a gama de fatores que afetam a mesma; como habitat, alimentação, período reprodutivo, tecnologias empregadas, entre outros.

\subsubsection{Determinação instrumental da textura}

A textura dos camarões também é uma característica sensorial importante e, como a cor, é determinante na aceitação do produto pelo consumidor. A mensuração destes atributos por um painel sensorial é complexa, demanda tempo e está sujeita a erro, pela variabilidade do julgamento humano (ANSORENA et al., 1997). Portanto, a determinação instrumental destes parâmetros pode ser bastante útil para qualificar os produtos alimentícios.

De acordo com a literatura científica a deterioração do pescado é causada principalmente pela ação de microrganismos, indicando também que camarões 
frescos apresentam textura relativamente firme, perdendo a firmeza durante o armazenamento sob refrigeração.

Segundo Leonel et al.(2010) o parâmetro da firmeza ou dureza representa a força $(\mathrm{N})$ necessária para obter a deformação na primeira compressão, o que representaria a primeira mastigação. A média para a firmeza instrumental dos camarões sete-barbas 24 horas após o desembarque foi de 6,58 $\mathrm{N} \pm 1,00$, com variação de 3,64 a 7,79 $\mathrm{N}$ entre as médias das amostras.

Os camarões avaliados sensorialmente como "muito bons" tiveram valores médios para a firmeza entre 6,06 a 7,79 N. Se considerarmos estes valores como padrão de qualidade para a espécie temos que 25\% dos camarões amostrados apresentaram textura inadequada.

No entanto, a maioria das amostras que se apresentaram menos firmes também tinham menor comprimento médio. Este fato pode explicar a grande porcentagem de amostras com firmeza reduzida, uma vez que as capturas resultaram muitas vezes em camarões pequenos.

Segundo Hyldig e Nielsen (2001), muitos fatores afetam a textura do pescado, como a espécie, tamanho, idade e estado nutricional; fatores post mortem, incluindo a glicólise, $\mathrm{pH}$ e rigor mortis e também fatores externos, como a temperatura de armazenamento, o teor de sal e a temperatura de processamento e/ou preparo.

No presente estudo a firmeza instrumental apresentou correlação linear $(\mathrm{r}=$ $0,71, \mathrm{p}<0,05)$ com o pH dos camarões, ou seja, os camarões com menor $\mathrm{pH}$ apresentam textura mais firme e consequente melhor apreciação. Gökodlu, Özden e Erkan (1998) observaram que sardinhas estocadas por 10 dias a $4^{\circ} \mathrm{C}$ apresentaram firmeza reduzida ao longo do período de armazenamento sob refrigeração, enquanto o $\mathrm{pH}$ se elevava.

Pornrat et al., (2007) apontaram que o aumento da temperatura leva ao amolecimento precoce do pescado, uma vez que propicia o desenvolvimento microbiano e que a velocidade de decomposição do pescado depende do número e da espécie das bactérias infectantes, uma vez que há grande variação no comportamento destas quanto a capacidade de causar deterioração. Portanto, os cuidados com o trinômio tempo $\mathrm{X}$ temperatura $\mathrm{X}$ higiene são determinantes na qualidade do pescado. 
Nunak e Schleining (2011) obtiveram uma força de compressão de 9,30 N para o camarão Litopenaeus vannamai, utilizando um probe cilíndrico de $50 \mathrm{~mm}$ de diâmetro e uma velocidade de $1,0 \mathrm{~mm} / \mathrm{s}$.

\subsubsection{Mercúrio $(\mathrm{Hg})$}

Apesar do pescado já ter sido apontado como a principal fonte de exposição ao mercúrio (BRASIL, 1999). A determinação do mercúrio por ICP-OES resultou em valores sempre $<0,05 \mathrm{mg} \cdot \mathrm{Kg}^{-1}$ da porção cárnea de camarão. Indicando que os desembarques da região de estudo oferecem camarões que se apresentam abaixo dos limites máximos legislados para este contaminante químico de $0,5 \mathrm{mg}$. $\mathrm{Kg}^{-1}$ (BRASIL, 1998).

\subsubsection{ANÁLISES MICROBIOLÓGICAS}

\subsubsection{Staphylococcus coagulase positiva e Salmonella spp}

Heinitz et al., (2000) analisaram os dados obtidos pelos laboratórios do FDA no período de 8 anos (1990 a 1998), quanto a presença de Salmonella, revelando que aproximadamente $10 \%$ dos produtos de pescado importados pelos EUA e 2,8\% dos produtos nacionais in natura obtiveram resultado positivo para Salmonella naquele período. 
A Salmonella spp é o principal microrganismo causador de surtos no Brasil, tendo sido responsável por 1195 casos em 2007 (COVEH, 2011).

Normalmente associada às aves, é bastante comum no pescado em função da presença maciça destas no momento da captura, bem como, muitas vezes nas áreas de desembarque e ainda, de comercialização. Entretanto, a Salmonella spp não foi detectada em quaisquer das amostras de camarão sete-barbas no presente estudo.

Os Staphylococcus aureus podem causar intoxicação alimentar grave. No entanto, é uma bactéria vulnerável ao tratamento térmico e a quase todos os agentes de desinfecção. Assim, sua presença em alimentos é geralmente uma indicação de práticas de sanitização deficientes (Seafood Network Information Center, 2007).

As contagens obtidas para $S$. aureus nos camarões sete-barbas estudados foram sempre $<10$ UFC. $\mathrm{g}^{-1}$. Portanto os camarões sete-barbas desembarcados na Baixada Santista atenderam aos requisitos microbiológicos estipulados no país para o pescado in natura (BRASIL, 2001).

\subsubsection{Coliformes totais e termotolerantes}

As contagens de colifomes totais - CT e coliformes termotolerantes - CF apresentaram valores < 0,3 a $24 \mathrm{NMP}^{-1}{ }^{-1}$ de porção cárnea. Os CF foram encontrados em 35\% das amostras, indicando contaminação ambiental recente por esgotos e/ ou deficiente prática higienico-sanitária e risco de infecção pelo consumo do produto cru ou pouco cozido. A maior contagem de CF ocorreu para a amostra oriunda da pesca sem o uso do gelo e os CT ocorreram em $85 \%$ das amostras, mas em contagens aceitáveis.

Estas contagens não são contempladas pela legislação nacional, mas a enumeração de coliformes totais é muito utilizada em indústrias alimentícias 
indicando poluição pré-sanitização, contaminação pós-sanitização ou pós-processo, evidenciando a adequação das práticas de higiene e sanitização requeridas no processamento de alimentos (PÁDUA, 2003).

\subsubsection{Clostridium perfringens}

A ingestão de alimentos contendo grande população de $C$. perfringens pode ocasionar intoxicação alimentar, devido à sua capacidade de produzir enterotoxina, que é liberada no intestino humano durante o processo de esporulação (MINOZZO, 2010).

A pesquisa de Clostridium perfringens obteve contagens de $<10$ a $10^{2} \mathrm{UFC} \mathrm{g}^{-}$ ${ }^{1}$, indicando a necessidade de cuidados com a preservação do camarão evitando-se o aumento das contagens e consequente formação de toxina.

$\mathrm{O} C$. perfringens é classificado em cinco tipos toxigênicos, de $\mathrm{A}$ a $\mathrm{E}$, dependendo da toxina produzida, sendo o tipo A, a principal causadora de toxinfecções alimentares. Além das quatro principais toxinas (alfa, beta, épsilon e iota), existem pelo menos outras 17 que podem ou não estar relacionadas aos diversos quadros clínicos observados em humanos e animais. Dentre essas, a enterotoxina CPE tem uma participação confirmada nos casos de toxinfecção alimentar causadas por Clostridium perfringens (PIRES; SILVA, LOBATO, 2011).

No Brasil, o C. perfringens é relatado como o quarto agente causal mais frequente das doenças transmitidas por alimentos (DTAs), tendo sido registrados 130 casos, em 2007 (COVEH, 2011). Apesar de raramente causar morte, a doença pode ocorrer em forma de surtos de proporção variável, no caso de fontes de alimento comum, além de ser potencialmente fatal em pessoas debilitadas, idosos e crianças.

Vale ressaltar, que a enterotoxina apresenta termoresistência, portanto, medidas preventivas evitando-se a proliferação dos clostrídios nos camarões são 
necessárias, uma vez que podem sobreviver em alimentos que são inadequadamente processados.

\subsubsection{ANÁLISE SENSORIAL}

Como apresentado na Tabela 3, a aceitação sensorial para o camarão setebarbas in natura foi em média de 4,8 \pm 1,67 qualificando os camarões em "gosto moderadamente". Apenas 55\% das amostras tiveram aceitação sensorial máxima, 6 "gosto muito", sendo esperada uma proporção superior de camarões nesta categoria, uma vez que se trata do primeiro elo desta cadeia produtiva.

Camarões sete-barbas com até $33 \mathrm{mg}$ N. $100 \mathrm{~g}^{-1}$ de músculo apresentaram aceitação sensorial máxima "gosto muito". Porém, a aceitação sensorial do camarão sete-barbas é restrita, uma vez que sua aparência rapidamente é comprometida pelo escurecimento e/ou aparecimento da "melanose", causada pela ação enzimática.

A baixa aceitação sensorial para as amostras provenientes da pesca de "sol a sol", quase sempre foi justificada pela coloração "escurecimento". As análises sensoriais ocorreram 24 horas após o desembarque, período suficiente para alterações na cor para esta espécie de camarão.

No entanto, a única amostra proveniente da pesca de "sol a sol" rejeitada sensorialmente foi oriunda de uma pesca sem uso do gelo, o que comprometeu a sua qualidade geral, principalmente, com as altas temperaturas da região no período ( $\left.30^{\circ} \mathrm{C}\right)$.

Os camarões provenientes da pesca de "sol a sol" e que se apresentam livres de sulfitos, no geral, obtiveram melhor aceitação sensorial que os oriundos da pesca de "baleeiras", provavelmente por se apresentarem mais frescos (menor tempo 
embarcado) e/ou porque o clareamento do camarão, provocado pelo uso do sulfito, não seja uma característica tão apreciada pelos consumidores.

No entanto, no presente caso, o uso do sulfito é coincidente com um maior período embarcado, ou seja, com uma deterioração mais avançada.

Do total de quatro embarcações tipo "baleeira" amostradas, duas desembarcaram camarões sete-barbas que foram rejeitados sensorialmente. Segundo Huidobro; Lópes Caballero, Mendes (2002), a manipulação a bordo das embarcações é determinante para assegurar a alta qualidade do produto, tanto para o consumo fresco quanto para o processamento industrial.

\subsubsection{ANÁLISE GLOBAL}

A análise global dos parâmetros de qualidade estudados mostrou que os camarões estavam em desacordo com os limites propostos pelo RIISPOA (BRASIL, 1952), embora atendessem os padrões microbiológicos exigidos pelo Ministério da Saúde (BRASIL 2001) e, em alguns casos, terem sido qualificados sensorialmente como "muito bom". Indicando a necessidade de adequação dos limites estipulados para os parâmetros físico e químicos nacionais vigentes para a qualificação do camarão sete-barbas para o consumo.

Considerando que as amostras foram coletadas no primeiro elo da cadeia produtiva, onde é suposto que o alimento tenha a máxima qualidade, sugere-se que o tratamento a bordo e no desembarque deve ser melhorado, evitando-se o risco de infecção pelo consumo deste produto pesqueiro. Além disso, a garantia da manutenção da cadeia do frio durante todo o percurso até o consumidor é primordial para a segurança no consumo deste pescado, visto os pontuados malefícios que o abuso da temperatura pode acarretar. 
A redução da produção de camarão sete-barbas no período do estudo vem intensificar a necessidade de ferramentas para valorização do produto desembarcado, minimizando as perdas e propiciando o aproveitamento integral deste produto pesqueiro;

É iminente a adequação de uso dos sulfitos aplicados aos camarões para evitar a autólise enzimática e, consequente formação de manchas negras, sendo primordial a declaração do seu conteúdo na etiqueta do produto. $\mathrm{O}$ uso apropriado dos sulfitos e as boas práticas devem ser indicados nas instruções do fabricante;

A harmonização das atividades de pesquisa e de físcalização, quanto aos métodos analíticos utilizados, é imprescindível para a obtenção de dados comparáveis e/ou complementares e, consequentemente, para que sejam disponibilizados padrões de qualidade mais adequados às diferentes espécies de pescado encontradas no país.

\subsection{CONCLUSÃO}

Sugerem-se, com vistas a classificação de um lote de camarão sete-barbas como aceitável para o consumo, os seguintes limites: $\mathrm{pH} \leq 7,7$; NBVT $\leq 35 \mathrm{mg}$. 100 $\mathrm{g}^{-1}$ de músculo e firmeza muscular (entre os 2 primeiros segmentos da cauda) $>6 \mathrm{~N}$, sendo desejável valores superiores para o camarão recém desembarcado.

Há camarões sete-barbas com qualidade comprometida sendo desembarcados na região metropolitana da baixada santista. 


\section{REFERÊNCIAS}

1. ANSORENA, D.; DE PEÑA, M.P.; ASTIASARÁN, I.; BELlO, J. Colour evaluation of chorizo de Pamplona, a Spanish dry fermented sausage: Comparison between the CIE L* a* b* and the Hunter lab systems with illuminants D65 and C. Meat Science, v.46, n.4, p.313-318, 1997.

2. BOTTA, J.R. Freshness quality of seafoods: a review. In: SHAHIDI, F.; BOTTA, J.R. (Eds.). Seafoods: Chemistry, Processing Technology and Quality. New York: Blackies Academic \& Professional, 1994. p. 140-167.

3. BRANCO, J.O. Biologia e pesca do camarão-sete-barbas Xiphopenaeus kroyeri (Heller) (Crustacea, Penaeidae) na estação de Itapocoroy, Penha, Santa Catarina, Brasil. Revista brasileira de zoologia, v.22, n.4, p.1050-1062, 2005.

4. BRASIL. Ministério da Agricultura. Regulamento de Inspeção Industrial e Sanitária de Produtos de Origem Animal (R.I.I.S.P.O.A): Decreto n ${ }^{\circ} 30.691$ de 29 de março de 1952. Seção 1, Capítulo 7 - Pescados e Derivados. Diário Oficial da União, Brasília, DF. jul.1952. p.71-73.

5. BRASIL. Ministério da Agricultura. Métodos analíticos oficiais para controle de produtos de origem animal e seus ingredientes: II - Métodos físicos e químicos. Secretaria Nacional de Defesa Agropecuária. Laboratório Nacional de Referência Animal. Brasília, DF. 1981.

6. BRASIL. Ministério da Saúde. Resolução CNS/MS $\mathrm{n}^{\circ} 04$, de 24 de novembro de 1988, do Conselho Nacional da Saúde. Diário Oficial da União, Brasília, DF. dez. 1988. Seção 1.

7. BRASIL. Ministério da Saúde. Princípios Gerais para o Estabelecimento de Níveis Máximos de Contaminantes Químicos em Alimentos. Portaria n ${ }^{\circ}$ 685, de 27 de agosto de 1998. Diário Oficial da União, Brasília, DF. set. 1998. 
8. BRASIL. Ministério da Agricultura, Pecuária e Abastecimento. Plano nacional de controle de resíduos em produtos de origem animal. Secretaria de Defesa Agropecuária. Instrução normativa $n^{\circ}$ 42, de 20 de dezembro de 1999. Brasília, DF. 1999.

9. BRASIL. Ministério da Saúde. Agência Nacional da Vigilância Sanitária. Regulamento técnico sobre padrões microbiológicos em alimentos. Resolução RDC n 12 , de 2 de janeiro de 2001.

10. BRASIL. Ministério da Agricultura, Pecuária e do Abastecimento. Secretaria de Defesa Agropecuária. Métodos analíticos oficiais para análises microbiológicas para controle de produtos de origem animal e água. Instrução Normativa $n^{\circ}$ 62, de 26 de agosto de 2003. Diário Oficial da União, Brasília, DF. 2003. Seção 1, p.14.

11. BRASIL. Ministério da Agricultura, Pecuária e Abastecimento. Instrução Normativa $\mathrm{n}^{\circ} 25$, de 2 de junho de 2011. Diário Oficial da União, Brasília, DF. 2011.

12. CHANG, O.; CHEUK, W.L.; NICKELSON, R., MARTIN, R., FINNE, G. Indole in shrimp: Effect of fresh storage temperature, freezing and boiling. Journal of Food Science, n.48, p. 813-816, 1983.

13. CHINIVASAGAM, H.N.; BREMNER, H.A.; WOOD, A.F.; NOTTINGHAM, S.M. Volatile components associated with bacterial spoilage of tropical prawns. International Journal of Food Microbiology, v.42, p.45-55, 1998.

14. COVEH. Coordenação de Vigilância das Doenças de Transmissão Hídrica e Alimentar. Ministério da Saúde. Doenças Transmitidas por água e alimentos. Secretaria de Vigilância em Saúde. 2011 Disponível em: ftp://ftp.cve.saude.sp.gov.br/doc_tec/hidrica/doc/6CPerfring_rev2011.pdf . Acesso em: 24 nov 2012.

15. FAO. Food and Agriculture Organization of the United Nations. Capture production 1950-2005. FISHSTAT Plus - Universal software for fishery statistical time series, 2007. Disponível em: 〈http://www.fao.org/fishery/topic/16073〉. Acesso em: 27 Oct 2009. 
16. FAO. Food and Agriculture Organization of the United Nations. FAO yearbook 2010 - Fishery and Aquaculture Statistics. Rome: Fisheries and Aquaculture Department, 2012a. 81p.

17. FARINHA, A. New quality monitoring and prediction systems for production management (QIM, indole and other chemical indices). 2006. Disponível em: <http://cordis.europa.eu/search/index.cfm?fuseaction=result.document\&RS_LANG= EN\&RS_RCN=8267392\&q>. Acesso em: 15 Sept 2012.

18. FURLAN, E.F.; TORRES, E.A.F.S. Segurança alimentar na cadeia produtiva do camarão sete-barbas (Xiphopenaeus kroyeri). In: SIMPÓSIO DE CIÊNCIA E TECNOLOGIA DE ALIMENTOS, 2., CONGRESSO DO INSTITUTO NACIONAL DE FRUTOS TROPICAIS, 1., Aracaju, SE. Anais...Sergipe: SBCTASE, 2010. (CD-ROOM-ISBN: 978-85-63641-00-7)

19. FURLAN, E.F.; GALUZZI SILVA, C.M.; TOMITA, R.Y.; BARBOSA, K.O.; TORRES, E.F.S. Avaliação da coloração de camarões sete-barbas (Xiphopenaeus kroyeri) nas frotas pesqueiras de Santos e Guarujá. In: SIMPÓSIO DE CONTROLE DA QUALIDADE DO PESCADO, 5., Santos, SP, Anais...São Paulo: Instituto de Pesca, 2012. (CD-ROOM - ISSN: 1983-1854)

20. GÖKODLU, N.; ÖZDEN, Ö; ERKAN, N. Physical, chemical and sensory analysis of freshly harvested sardines (Sardina pilchardus) stored at $4^{\circ} \mathrm{C}$. Journal of Aquatic Food Product Technology, v.7, n.2, p.5-15, 1998.

21. GONÇALVES, A.C.; ANTAS, S.E.; NUNES, M.L. Freshness and quality criteria of iced farmed senegale sole (Solea senegalensis). Journal of Agricultural and Food Chemistry, v.55, p.3452-3461, 2007.

22. GONÇALVES, A.A.; JUNIOR, C.S.G.G. The effect of glaze uptake on storage quality of frozen shrimp. Journal of Food Engineering, n.90, p.285-290, 2009. 
23. GONÇALVES, A.C. Qualidade e valorização em aquacultura: propriedades sensoriais e período de conservação útil de peixe e bivalves. 2010. 65p. Tese (Doutorado em Farmácia - Bromatologia) - Faculdade de Farmácia, Universidade de Lisboa, Lisboa.

24. GRAM, L.; HUSS, H.H. Microbial spoilage of fish and fish products. International Journal of Food Microbiology, v.33, p.121-137, 1996.

25. HEINITZ, M.L.; RUBLE, R.D.; WAGNER, D.E.; TATINI, S.R. Incidence of Salmonella in fish and seafood. Journal of Food Protection, v.63, n.5, p.79-592, 2000 .

26. HILLERY, B.R.; ELKINS; E.R.; WARNER, C.R.; DANIELS, D.; THOMAS, F. Optimized Monier-Williams Method for determination of sulfites in foods: collaborative study. J. A.O.A.C., v.72, n.3, p. 470-475, 1989.

27. HORTON, L.R.; WRIGHT, B., WRIGHT, E. International Food \& Agricultural Trade Policy Council. IPC Position Paper - Standards Series. 2008. Disponível em: <http://www.agritrade.org/Publications/documents/IPCStandardsPositionPaper.pdf > Acesso em: 20 Oct. 2009.

28. HORWITZ, W. Official Methods of Analysis of the Association of Official Analytical Chemists. 18th ed. Cap. 9. Gaithersburg, Maryland: AOAC, 2005.

29. HOWGATE, P. A critical review of total volatile bases and Trimethylamine as indices of freshness of fish. Part 2. Formation of the bases, and application in quality assurance. EJEAFChe, v.9, n.1, p. 58-88, 2010.

30. HOYLAND, D.V.; TAYLOR, A.J. A review of the methodology of the 2thiobarbituric acid test. Food Chemistry, v.40, 271-291, 1991. 
31. HUIDOBRO, A.; LÓPES CABALLERO, M.E.; MENDES, R. On processing of deepwater pink shrimp (Parapenaeus longirostris) with liquid ice: Effect on quality. Eur. Food Res Technology, n.214, p. 469-475, 2002.

32. HYLDIG, G.; NIELSEN, D. A review of sensory and instrumental methods used to evaluate the texture of fish muscle. Journal of Texture Studies, v.32, n.3, p.19-242, 2001.

33. IBAMA. Ministério do Meio Ambiente. Instituto Brasileiro do Meio Ambiente e dos Recursos Naturais Renováveis. Diretoria de uso Sustentável da Biodiversidade e Florestas. DIAS NETO, J. Coordenação-Geral de Autorização de uso e Gestão de Fauna e Recursos Pesqueiros. Proposta de Plano Camarões Marinhos no Brasil. Brasília, 2011. 242p.

34. INSTITUTO ADOLFO LUTZ. Normas Analíticas do Instituto Adolfo Lutz. Métodos químicos e físicos para análise de alimentos, 4 ed. São Paulo: IMESP, 2008. 514p.

35. KE, P.J.; LINKE, B.A.; SMITH-LAA, B. Quality preservation and shelf lif estimation of frozen fish in terms of oxidative rancidity development. Lebensm. Wiss. Technol., v.15, p.203-206, 1982.

36. LABBE, R.G. Clostridium perfringens. In: DOWNES, F.P; ITO, K. (Eds.) Compendium of Methods for the Microbiological Examination of Foods, 4.ed. Washington DC.: American Public Health Association, 2001. p. 325-330.

37. LEONEL, M.; MARTINS, J.C.; MISCHAN, M.M. Produção de snacks funcionais à base de farinha de soja e polvilho azedo. Ciência Rural, Santa Maria, v.40, n.6, 2010. Disponível em: <http://www.scielo.br/scielo.php?pid=S0103$\underline{84782010000600028 \& \text { script=sci_arttext }>}$. Acesso: 2 jul.12. 
38. MACHADO, T.M.; FURLAN, É.F.; NEIVA, C.R.P.; CASARINI, L.M.; ALEXANDRINO DE PÉREZ, A.C.; LEMOS NETO, M.J.; TOMITA, R.Y. Fatores que afetam a qualidade do pescado na pesca artesanal de municípios da costa sul de São Paulo, Brasil. Boletim do Instituto de Pesca, São Paulo, v.36, n.3, p.213-223, 2010.

39. MEILGAARD, M.; CIVILlE, G.V.; CARR, B.T. Sensory evaluation techniques. Boca Raton: CRC Press, 1999. v.3, 354p.

40. MENDES, R.; GONÇALVES, A.; PESTANA, J.; PESTANA, C. Indole production and deepwater pink shrimp (Parapenaeus longirostris) decomposition. European Food Research and Technology, v.221, n.3-4, p. 320-328, 2005.

41. MENDES, R. Guidebook on melanosis inhibitors and processing technology of crustaceans. Algés, Lisboa: INIAP/IPIMAR, 2006. Project QLK1CT-2002-71517 (CRUSTAMEL New approaches to the crustaceans prevention of melanosis and quality indices). 41p.

42. MINOZZO, M.G. Patê de pescado: alternativa para incremento da produção nas indústrias pesqueiras. 2010. 206p. Tese (Doutorado em Tecnologia de Alimentos) - Universidade Federal do Paraná, Curitiba.

43. MOURA, A.; DEL BEN MAYER, M.; LANDGRAF, M.; TENUTA FILHO, A. Qualidade química e microbiológica de camarão-rosa comercializado em São Paulo. Brazilian Journal of Pharmaceutical Sciences, v.39, n.2, p. 203-208, 2003.

44. NIAMNUY, C; DEVAHASTIN, S.; SOPONRONARIT, S. Changes in proteins compositions on physical changes of shrimp during boiling in salt solution. Food Chemistry, v.108, p.165-175, 2008.

45. NUNAK, N.; SCHLEINING, G. Instrumental textural changes in raw White shrimp during iced storage. Journal of Aquatic Food Product Technology, v.20, p.350-360, 2011.

46. OGAWA, N.B.P.; ARAÚJO, I.W.F.; LUCENA, L.H.L.; MAIA, E.L.; OGAWA, M. Teor residual de SO2 em camarões congelados exportados pelo estado do Ceará. Boletim Técnico do CPNOR, Belém, v.3, n.1, p.191-196, 2003. 
47. OGAWA, M; MAIA, E.L., FERNANDES, A.C.; NUNES, M.L.; OLIVEIRA, M.E.B.; FREITAS, S.T. Resíduos do beneficiamento do camarão cultivado: obtenção de pigmentos carotenoides. Ciência e Tecnologia de Alimentos, Campinas, v.27, n.2, p. 333-337, 2007.

48. OSAWA, C.C.; DE FELÍCIO, P.E.; GONÇALVES, L.A.G. Teste de TBA aplicado a carnes e derivados: métodos tradicionais, modificados e alternativos. Química Nova, v.28, n.4, p.655-663, 2005.

49. OTWELL, W.S.; FLICK, Jr.G.J. A HACCP program for raw, cultured Penaeid shrimp. USA: Florida Sea Grant College Program, 1995. p. 218-226. (FLSGP-R-95-001 C3).

50. PÁDUA, H.B. de. Informações sobre os coliformes totais/ fecais e alguns outros organismos indicadores em sistemas aquáticos - Aqüicultura, 2003. 20p. Disponível em: 〈http:// www.setorpesqueiro.com.br>. Acesso em: 12 ago 2009.

51. PIRES, P.S.; SILVA, R.O.S.; LOBATO, F.C.F. Programa de zoonoses região sul. Manual de zoonoses. Conselho Regional de Medicina Veterinária, v.2, n.1, 2011.

52. PORNRAT, S.; SUMATE, T.; ROMMANEE, S.; SUMOLAYA, K.; KERR, W.L. Changes in the ultrastructure and texture of prawn muscle (Macrobrachuim rosenbergii) during cold storage. LWT - Food Science and Technology, v.40, n.10, p. 1747-1754, 2007.

53. SARNOSKI, P.J. Instrumental Methods for Determining Quality of Blue Crab (Callinectes sapidus) Meat. 2007. 115p. (Thesis) - Virginia Polytechnic Institute and State University, Blacksburg. Disponível em:< http://scholar.lib.vt.edu/theses/available/etd-05152007-

121919/unrestricted/Sarnoski_Thesis.pdf >. Accesso em: 14 Apr. 2012.

54. SEAFOOD NETWORK INFORMATION CENTER. Sea Grant Extension Program. Chapter 19: Staphylococcus aureus. Potential Food Safety Hazard, 2007. Disponível em: http://seafood.ucdavis.edu/haccp/compendium/chapt19.htm\#Potential Food Safety Hazard.>. Acesso em: 25 Nov. 2012 
55. SEVERINO-RODRIGUES, E.; PITA, J.B.; GRAÇA-LOPES, R.; COELHO, J.A.P.; PUZZI, A. Aspectos biológicos e pesqueiros do camarão sete-barbas (Xiphopenaeus kroyeri) capturado pela pesca artesanal no litoral do Estado de São Paulo. Boletim do Instituto de Pesca, São Paulo, v.19, p.67-81, 1993.

56. THAMPURAN, N.; GOPAKUMAR, K. Impact of handling practices on the microbial quality of shrimp (Metapenaeus dobsoni). Roma: FAO, 1990. (FAO Fisheries Report). p. 47-52.

57. U.E. Regulamento (CE) $\mathrm{n}^{\circ} 2074 / 2005$ da comissão de 5 de Dezembro de 2005. Jornal Oficial da União Europeia, L 338, p.27- 59, 2005.

58. VYNCKE, W. Direct determination of the thiobarbituric acid value in trichloracetic acid extracts of fish as a measure of oxidative rancidity. Fette Seifen Anstrichmittel, v.72, n.12, p.1084-1087, 1970.

59. WHO. WORLD HEALTH ORGANIZATION. WHO FOOD ADDITIVES. Safety evaluation of certain food additives. In: Meeting of the Joint FAO/WHO (JECFA), 69., 2009, Geneva. Proceedings...Geneva: WHO, IPCS - International Programme on Chemical Safety, 259p.

60. YOKOYAMA, V.A. Qualidade do camarão da espécie Xyphopenaeus kroyeri mediante a ação dos agentes antimelanóticos. 2007. 124p. Dissertação (Mestrado em Ciência e Tecnologia de Alimentos) - Departamento de Agroindústria, Alimentos e Nutrição, Escola Superior de Agricultura Luiz de Queiroz, Universidade de São Paulo, Piracicaba, SP. 


\section{CAPÍtulo 3 - DESENVOLVIMENTO DE PROTOCOLO PARA OTIMIZAÇÃO DA AVALIAÇÃO SENSORIAL DO FRESCOR PARA O CAMARÃO MARINHO Xiphopenaeus kroyeri ARMAZENADO EM GELO}

\section{Resumo}

Os crustáceos são altamente perecíveis e a análise sensorial tem sido uma ferramenta essencial para garantir a qualidade dos mesmos. Devido a subjetividade desta análise, em tempos recentes tem sido proposto o uso do Quality Index Method (QIM), que pode ser utilizado para garantir a qualidade, bem como, no planejamento da produção. Este estudo tem como objetivo desenvolver um protocolo QIM para o camarão marinho Xiphopenaeus kroyeri inteiro, armazenado em gelo, que possibilite discriminar o seu grau de frescor e estimar o período de vida útil. Para otimizar o protocolo de avaliação do frescor do camarão X. kroyeri, com e sem o uso de sulfito, foram conduzidos ensaios de vida útil empregando-se as análises física e químicas (pH, BNVT, TMA e aminas biogênicas), microbiológicas (S. aureus, Salmonella spp, coliformes totais, bolores e leveduras, contagens padrão de bactérias heterotróficas aeróbias psicotróficas e mesófilas) e testes sensoriais, onde utilizou-se o protocolo elaborado. O protocolo otimizado para a avaliação sensorial do frescor do camarão sete-barbas "in natura" inteiro, armazenado em gelo, consiste de 5 parâmetros e seus descritores, os quais somam 11 pontos de demérito e que pode ser utilizado em camarões tratados ou não com sulfito. Os camarões sete-barbas apresentam uma vida útil de 2 dias armazenados em gelo e o tratamento dos mesmos em solução de sulfito $(1,25 \%)$ pode estender a vida útil em 1 dia. Sendo que, os camarões maiores podem ganhar até 2 dias na sua vida útil se, além do uso do 
conservante, estes forem classificados e manipulados adequadamente a bordo das embarcações.

Descritores: Crustáceos, Índice de Qualidade, Análise sensorial, Sete-barbas, vida útil. 


\section{PROTOCOL DEVELOPMENT TO OPTIMIZE FRESHNESS SENSORIAL EVALUATION OF THE MARINE SHRIMP Xiphopenaeus kroyeri STORED ON ICE}

Abstract

Crustaceans are highly perishable and sensory analysis has been an essential instrument to ensure their quality. Sensory analysis is subjective, so in recent times has been used the Quality Index Method (QIM), which can be used in quality assurance and production planning. This study aimed to develop a sensory evaluation protocol QIM for Raw whole marine shrimp Xiphopenaeus kroyeri, which allows to discriminate their degree of freshness and to estimate the shelf-life. To optimize the protocol for the evaluation of ice stored X.kroyeri shrimp freshness, treated or not with sulfite, trials of shelf life were conducted using physical and chemicals analyzes (pH, TVB-N, TMA and biogenic amines), microbiological (S. aureus, Salmonella spp, total coliforms counts, molds and yeasts, Mesophilic and Psychrotrophic Bacteria) and sensory analysis, where established protocol was used. The optimized protocol for the sensory evaluation of raw whole seabob-shrimp freshness, stored on ice, consists of five parameters and their descriptors, which total 11 demerit points and can be used in shrimps treated or not with sulfite. The seabob-shrimp stowed in crushed ice have 2 days of shelf-life and the dipping in metabisulphite solution $(1.25 \%)$ can extend the shelf-life up 1 day or up 2 days when the largest shrimp are classified and handled appropriately onboard vessels.

Key-words: Shellfish, Quality Index, Sensory Analysis, Sea-bob, shelf-life. 


\subsection{INTRODUÇÃO}

Os crustáceos são altamente perecíveis e a análise sensorial tem sido uma ferramenta essencial e o método mais utilizado para garantir o frescor e a qualidade dos mesmos.

No entanto, os métodos sensoriais são considerados subjetivos e apesar de apresentarem vantagens, como baixo custo, rapidez e relação direta com os padrões de aceitação do consumidor; exigem a participação de um número representativo de julgadores treinados para obtenção de resultados confiáveis e reprodutíveis, o que na prática não é viável.

Neste contexto, alternativamente, em tempos recentes, alguns autores vêm estabelecendo o Método do Índice de Qualidade, ou "QIM" para as diferentes espécies de importância comercial.

O QIM foi desenvolvido durante a década de 1980 na Tasmanian Food Research Unit (BREMNER, 1985) e baseia-se na avaliação dos atributos sensoriais considerados significativos (aparência, textura, olhos, odor, entre outros) através de um sistema de classificação por pontos de demérito (de 0 a 3), onde a soma dessas classificações quantifica a falta de qualidade sensorial até um valor máximo, específico de cada espécie/gênero, que corresponde à ausência total de qualidade (impróprio para consumo humano) e que se obtém a partir da análise sensorial do pescado por um painel restrito de julgadores treinados (HUSS, 1995).

O QIM já foi desenvolvido para uma gama de espécies de pescado de importância comercial. Segundo Martinsdóttir et al. (2003), trata-se de um método rápido e que tem sido indicado como referência na padronização e harmonização da avaliação sensorial do pescado na Europa. Estes autores ainda sugerem uma relação linear entre o QIM e o tempo de estocagem em gelo para diversas espécies de pescado, sendo uma ferramenta prática, objetiva e útil para a indústria da pesca. 
Esteves e Aníbal (2007) também indicaram o QIM como ferramenta para o estabelecimento da vida útil do pescado, uma vez que os resultados do QIM estão linearmente relacionados com o tempo de conservação.

Os consumidores, cada vez mais exigentes quanto a qualidade dos alimentos, também escolhem seus alimentos pela apreciação sensorial (MARTINSDÓTTIR et al., 2001). Portanto, faz-se extremamente útil o desenvolvimento de métodos que descrevam as propriedades sensoriais do alimento, caracterizando os seus atributos iniciais e as principais alterações que ocorrem ao longo do período de armazenamento (HUIDOBRO; PASTOR; TEJADA, 2000).

Segundo Hyldig e Nielsen (2004) e Nunes e Batista (2004) as vantagens do QIM são a sua objetividade, rapidez, requerer treinamento simples, além de não ser um método destrutivo. Portanto, pode ser utilizado como ferramenta no planejamento da produção e na garantia da qualidade, podendo também ser útil para dar gabarito aos pescadores a respeito da qualidade da sua captura, o que poderá influenciar positivamente a manipulação a bordo das embarcações pesqueiras (CARDENAS BONILLA; SVEINSDOTTIR; MARTINSDOTTIR, 2007).

Nesse sentido, com vistas a valorização da qualidade do camarão sete-barbas, este estudo tem como objetivos desenvolver e otimizar um esquema de avaliação sensorial que permita discriminar o grau de frescor e prever o período de vida útil do camarão marinho Xiphopenaeus kroyeri armazenado em gelo, com e sem a aplicação de sulfito $(1,25 \%)$. 


\subsection{MATERIAL E MÉTODOS}

\subsubsection{DELINEAMENTO DO ESTUDO}

Para o desenvolvimento do protocolo sensorial para o camarão marinho X.kroyeri inteiro armazenado em gelo, com e sem o uso de sulfito, foram realizados os procedimentos ilustrados na Figura 14.

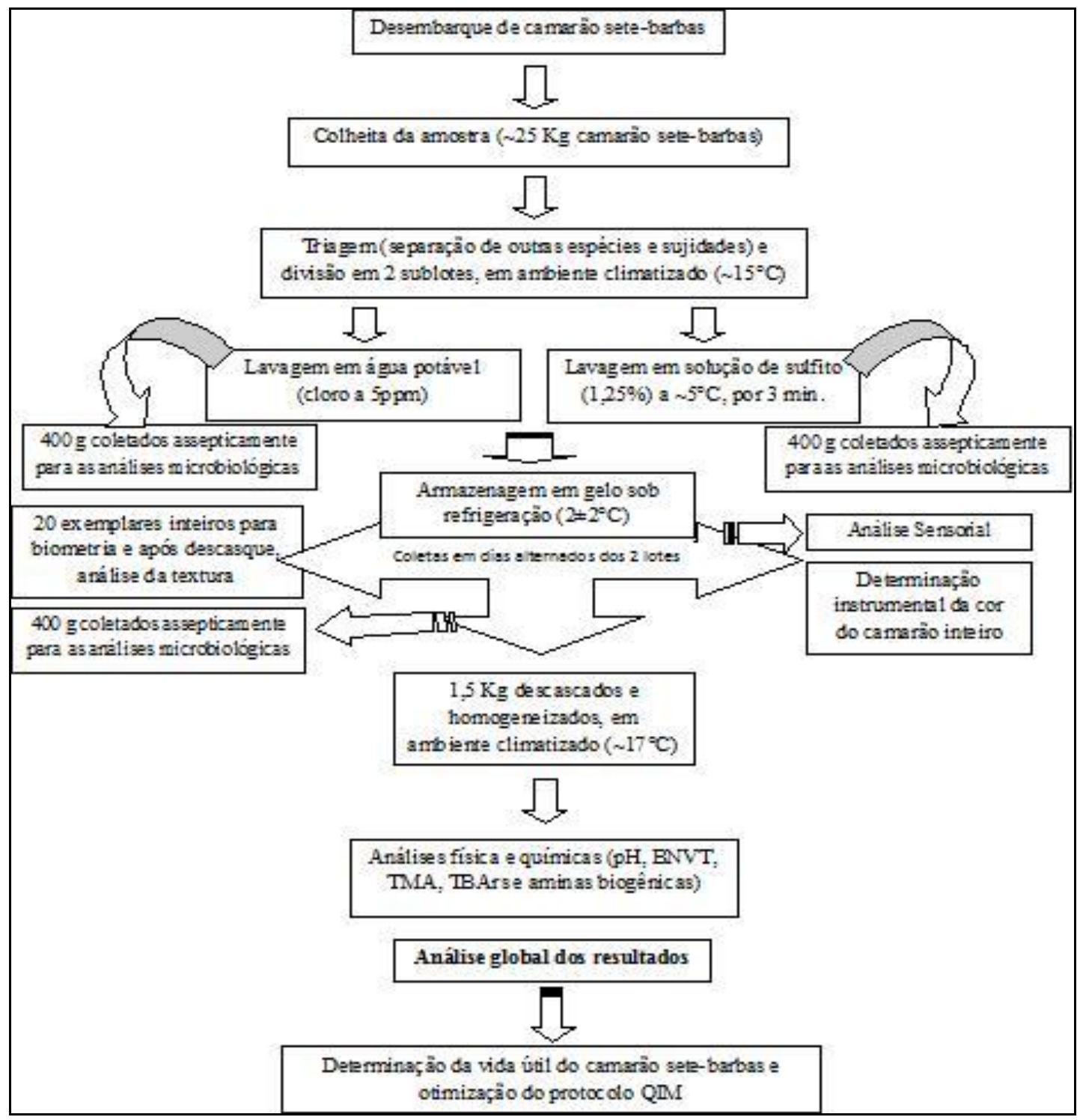

Figura 14. Procedimentos para a determinação da vida útil do camarão sete-barbas e para desenvolvimento e otimização do protocolo QIM para avaliação do seu frescor. 


\subsubsection{MATÉRIA-PRIMA}

Para o desenvolvimento do protocolo sensorial QIM e estudo da vida útil do camarão sete-barbas armazenado em gelo, foram realizadas 4 colheitas (4 lotes). Cada lote para um ensaio, mas todos oriundos de desembarque único, provenientes de pesca de "sol a sol" e livres de sulfito, totalizando 4 ensaios de vida útil.

O lote de aproximadamente $25 \mathrm{Kg}$, proveniente de uma única pescaria (Figura 15), foi lavado com água potável clorada a $5 \mathrm{mg} . \mathrm{Kg}^{-1}$ e dividido em dois sublotes, sendo um denominado "controle" (sem sulfito) e o segundo tratado com solução de metabissulfito de sódio a $1,25 \%$ a $5^{\circ} \mathrm{C}$, por 3 min. (Figura 16). A concentração e forma de aplicação seguiram o recomendado pela legislação nacional (BRASIL, 1977). O tempo foi determinado após revisão da literatura e objetivandose a viabilidade prática, uma vez que a legislação não o menciona (OMAR, 1998; MENDES, 2006; GÓES, 2005; U.E., 2006; YOKOYAMA, 2007).
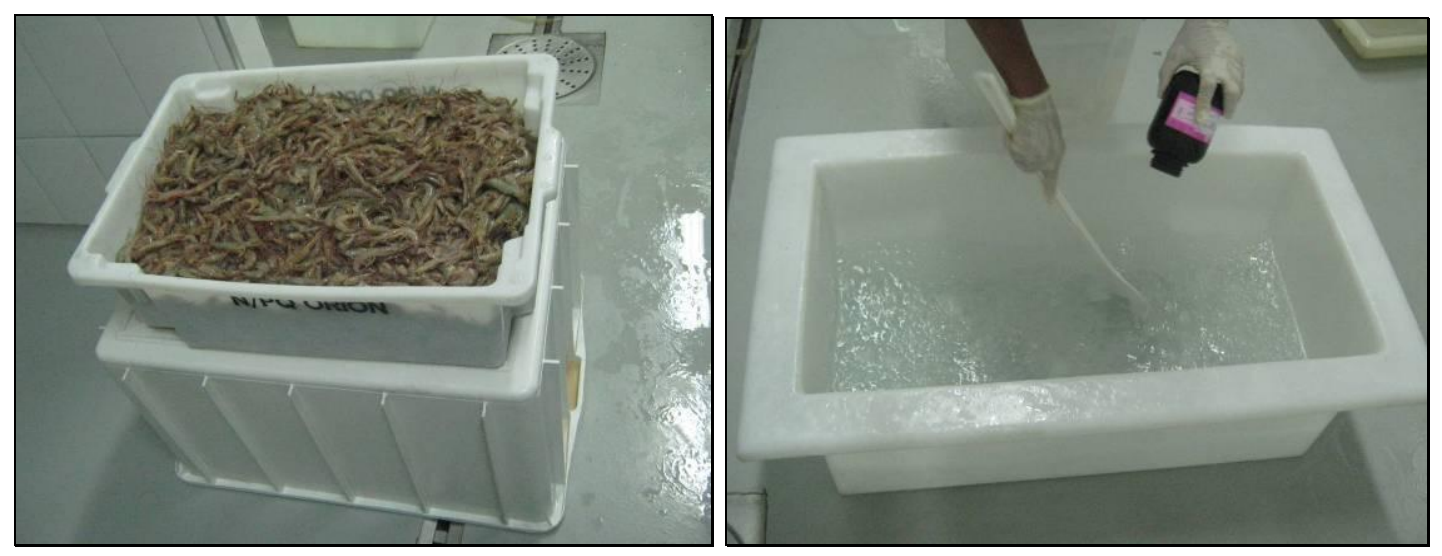

Figura 15. Lote de camarão sete-barbas in natura. Figura 16. Preparo da solução de sulfito de sódio.

Após triagem, lavagem e tratamento com sulfito, os camarões foram acondicionados em caixas plásticas perfuradas, cobertos com filme plástico e gelo escama e então, acondicionadas em refrigerador a $2 \pm 2{ }^{\circ} \mathrm{C}$. Após a lavagem e tratamento com sulfito, camarões dos tratamentos "controle" e "sulfito" foram amostrados para os ensaios microbiológicos e, periodicamente, em dias alternados, 
novas coletas foram realizadas para as determinações física, químicas, microbiológicas e sensoriais envolvidas no estudo.

O estudo de vida útil foi embasado em análises física e químicas $(\mathrm{pH}, \mathrm{BNVT}$ e TMA e aminas biogênicas), microbiológicas (S.aureus, Salmonella spp, coliformes totais, Bolores e Leveduras, contagens padrão de bactérias mesófilas aeróbias estritas e facultativas viáveis e de microrganismos psicrotróficos) e em testes sensoriais do camarão in natura, utilizando-se o protocolo proposto (Figura 17) e do camarão cozido, utilizando-se uma escala hedônica de 5 pontos (Anexo 4).

Para a realização dos ensaios microbiológicos, $400 \mathrm{~g}$ de camarão foram separados assepticamente e acondicionadas em sacos plásticos estéreis, lacrados e então, transportados ao laboratório de microbiologia em caixa isotérmica, previamente higienizada, identificada e com gelo.

Para os ensaios físico e químicos, o preparo das amostras consistiu no descasque de aproximadamente $1,5 \mathrm{Kg}$ do camarão em ambiente climatizado ( $17^{\circ} \mathrm{C}$ ) e homogeneização da porção cárnea em cutter por 1 min., incorporação das porções menos trituradas com auxílio de espátula e mais 1 min. em cutter. Obtendose uma pasta (amostra homogeneizada) que foi utilizada para as determinações do pH, BNVT, TMA e aminas biogênicas. As amostras destinadas a pesquisa de aminas biogênicas foram imediatamente pesadas, devidamente embaladas, identificadas e congeladas a $-80^{\circ} \mathrm{C}$.

\subsubsection{ANÁLISES FÍSICAS E QUÍMICAS}

\subsubsection{Determinação Biometria}

Foram realizadas medições do comprimento de camarões com auxílio de um paquímetro. Para cada amostra foram tomados aleatoriamente 20 espécimes. 


\subsubsection{Valor do $\mathrm{pH}$}

A determinação eletrométrica do $\mathrm{pH}$ foi realizada em triplicata, segundo as Normas Analíticas do Instituto Adolfo Lutz (2008), que se fundamenta na medida da concentração de íons hidrogênio em 10 gramas de amostra homogeneizada em 100 $\mathrm{mL}$ de água destilada.

\subsubsection{Bases Nitrogenadas Voláteis Totais (BNVT)}

Foram determinadas em triplicatas, de acordo com o método oficial do Ministério da Agricultura, Pecuária e Abastecimento (BRASIL, 1981). Utilizou-se $50 \mathrm{~g}$ da amostra homogeneizada, que após a precipitação do nitrogênio protéico com $150 \mathrm{~mL}$ de solução de ácido tricloroacético (TCA) 5\%, foi filtrada em filtro qualitativo, resultando em um extrato contendo o nitrogênio volátil. Então, $5 \mathrm{~mL}$ do extrato filtrado foi alcalinizado com hidróxido de sódio $(\mathrm{NaOH}) 2 \mathrm{M}$ e destilado a vapor, utilizando-se um destilador micro-Kjeldahl (Tecnal, Brasil) e recebido em solução de ácido bórico, até um volume aproximado de $50 \mathrm{~mL}$ e, sequencialmente, titulado com solução de ácido padronizado $(\mathrm{HCl} 0,01 \mathrm{~N})$ em presença do indicador ácido rosólico; até a viragem da cor amarela para o cor rosa. Como resultado obtevese o teor de nitrogênio proveniente de substâncias básicas voláteis totais, como amônia e aminas de cadeia curta, que se acumulam no músculo do pescado após a

morte. Os resultados dos vários compostos foram expressos em mg N.100 g $\mathrm{g}^{-1} \mathrm{de}$ músculo e obtidos pela equação que segue:

$$
\mathrm{BNVT}=\frac{14 \times(150+\mathrm{A}) \times(5-\mathrm{V}) \times \mathrm{fc} \times \mathrm{N} \times 100}{\operatorname{Va} \times \mathrm{P}}
$$


Onde, $\mathbf{1 4}$ = Eqg de nitrogênio; $\mathbf{1 5 0}=$ volume $(\mathrm{mL})$ da solução de TCA a 5\%; $\mathbf{A}=$ conteúdo de água contido na amostra expressa $(\mathrm{mL}) ;(\mathbf{5}-\mathbf{V})=(\mathbf{5} \mathbf{~ m L ~ H C L}-\mathbf{X}$ $\mathbf{m L ~} \mathrm{NaOH})=$ volume $(\mathrm{mL})$ de solução de ácido clorídrico $0,01 \mathrm{~N}$ adicionado no erlenmeyer que recebe o destilado e subtraídos do volume $(\mathrm{mL})$ de $\mathrm{NaOH} 0,01 \mathrm{~N}$ gasto na titulação $(\mathbf{V}) ; \mathbf{f c}=$ fator de correção da solução de $\mathrm{HCl} 0,01 \mathrm{~N} ; \mathbf{N}=$ normalidade da solução de $\mathrm{HCl}(\mathrm{mol} / \mathrm{L}) ; \mathbf{V a}=$ volume $(\mathrm{mL})$ da alíquota e $\mathbf{P}=$ massa da amostra em gramas.

\subsubsection{Trimetilamina (TMA)}

A determinação da TMA foi realizada sequencialmente a metodologia de BNVT. Após titulação, as triplicatas do extrato foram acrescidas da solução de formaldeído (FA) 16\% neutralizada, $1 \mathrm{~mL}$ de FA para cada $10 \mathrm{~mL}$ do extrato. O FA reage com as aminas, exceto a TMA então, titulou-se o ácido liberado (equivalente à trimetilamina) com solução de $\mathrm{NaOH} 0,01 \mathrm{~N}$ até a viragem de incolor para a cor rosa. Anotou-se o volume ( $\left.\mathbf{V}^{\prime}\right)$, em $\mathrm{mL}$, da solução de $\mathrm{NaOH}$ 0,01N gasto na $2^{\mathrm{a}}$ titulação, que corresponde ao volume $(\mathrm{mL})$ do ácido liberado, como proposto em Brasil (1981). Os resultados de TMA foram expressos em $\mathrm{mg} \mathrm{N} .100 \mathrm{~g}^{-1}$ de músculo e obtidos pela equação abaixo:

$$
\mathrm{TMA}=\frac{14 \times(150-5-\mathrm{A}) \times \mathrm{V}^{\prime} \times \mathrm{fc} \times \mathrm{N} \times 100}{\operatorname{Vax} \mathrm{P}}
$$

Onde: 14 = Eqg de nitrogênio; 5 = volume $(\mathrm{mL})$ da solução de FA a 16\%; 300 = volume $(\mathrm{mL})$ da solução de TCA a $5 \% ; \mathbf{A}=$ conteúdo de água na amostra expressa $(\mathrm{mL}) ; \mathbf{V}^{\prime}=$ volume $\left(\mathrm{mL}\right.$, de $\mathrm{NaOH} 0,01 \mathrm{~N}$ gasto na $2^{\mathrm{a}}$ titulação; $\mathbf{f} \mathbf{c}=$ fator de correção de solução de $\mathrm{HCl}$ 0,01 N; N= Normalidade da solução de $\mathrm{HCl} 0,01 \mathrm{~N} ; \mathbf{V a}=$ volume da alíquota $(\mathrm{mL})$ e $\mathbf{P}=$ massa da amostra $(\mathrm{g})$. 


\subsubsection{Aminas Biogênicas}

As amostras previamente congeladas a $-80^{\circ} \mathrm{C}$ foram descongeladas em temperatura de refrigeração $\left(\sim 10^{\circ} \mathrm{C}\right)$. Então, $5 \mathrm{~g}$ da amostra foram utilizadas para a extração ácida das aminas. O tempo total de extração nunca excedeu 5 horas. Nas amostras fortificadas com as soluções padrão, o volume de PCA 0,2 mol. $\mathrm{L}^{-1}$ adicionado considerou o volume dos padrões adicionados, obtendo-se sempre um volume final de $10 \mathrm{~mL}$. Centrifugou-se a $8000 \mathrm{rpm}$ por $10 \mathrm{~min}$, à temperatura de $4^{\circ} \mathrm{C}$. Coletou-se $200 \mu \mathrm{L}$ do sobrenadante para tubo de centrífuga de $15 \mathrm{~mL}$. Adicionou-se $400 \mu \mathrm{L}$ de solução saturada de bicarbonato de sódio, agitou-se rapidamente para misturar e, em seguida, se adicionou $800 \mu \mathrm{L}$ de solução de cloreto de Dansila. Agitou-se em vórtex por aproximadamente 30 segundos e deixou ao abrigo da luz, em banho de água quente a aproximadamente $60^{\circ} \mathrm{C}$, por $5 \mathrm{~min}$. Retirou-se do banho e adicionou-se $200 \mu \mathrm{L}$ de solução de L-prolina. Agitou-se em vórtex, por aproximadamente 30 segundos e deixou ao abrigo da luz à temperatura ambiente, por $30 \mathrm{~min}$. Adicionou-se $1 \mathrm{~mL}$ de tolueno, agitou novamente em vórtex por 1 minuto e centrifugou a $8000 \mathrm{rpm}$ por $10 \mathrm{~min}$., à temperatura de $4^{\circ} \mathrm{C}$, para separação das fases. Recuperou-se a fase orgânica (sobrenadante) com auxílio de pipetador automático para tubo de ensaio de $5 \mathrm{~mL}$. No concentrador as amostras foram evaporadas por adição de fluxo de nitrogênio por 10 a 15 min., a uma temperatura de aproximadamente $60^{\circ} \mathrm{C}$. Dissolveu-se o extrato com $600 \mu \mathrm{L}$ de acetonitrila e filtrou em unidade filtrante, membrana de 0,45 micrometros de PTFE, direto para o frasco (vial) do cromatógrafo. A separação e quantificação foram realizadas por Cromatografia Líquida de Alta Eficiência com Gradiente de Eluição e Detecção Ultravioleta (CLAE/UV), como proposto em Brasil (2011), obtendo-se os cromatogramas das amostras, da curva de calibração e amostras para cálculo da recuperação no CLAE, equipado com coluna de fase reversa C18 (5 $\mu \mathrm{m}, 100 \AA, 25$ cm x 4,6 mm), detecção no UV a $254 \mathrm{~nm}$, utilizando injeção de $20 \mu \mathrm{L}$ e o seguinte gradiente: 


\begin{tabular}{ccc}
\hline $\begin{array}{c}\text { Tempo } \\
(\min )\end{array}$ & $\begin{array}{c}\text { Água } \\
(\%)\end{array}$ & $\begin{array}{c}\text { Acetonitrila } \\
(\%)\end{array}$ \\
\hline 0 & 40 & 60 \\
6 & 25 & 75 \\
8 & 25 & 75 \\
13 & 5 & 95 \\
20 & 5 & 95 \\
21 & 40 & 60 \\
30 & 40 & 60 \\
\hline
\end{tabular}

Os cromatogramas obtidos das amostras foram comparados aos cromatogramas de soluções padrão e os picos dos analitos confirmados pelo tempo de retenção $\left(\mathbf{t}_{\mathbf{R}}\right)$. A área total do pico de cada analito foi calculada pelo software do equipamento e o resultado é interpolado em uma curva padrão que relaciona a área total com a concentração do analito.

\subsubsection{ANÁLISES MICROBIOLÓGICAS}

\subsubsection{Staphylococcus aureus}

A contagem de S. aureus foi realizada de acordo com Brasil (2003). Pesou-se, assepticamente, $25 \mathrm{~g}$ de camarão sete-barbas in natura, adicionou-se $225 \mathrm{~mL}$ de solução salina peptonada $0,1 \%$, homogeneizou-se por aproximadamente 60 segundos em "stomacher", obtendo-se a diluição $10^{-1}$. A partir da diluição inicial $10^{-1}$ efetuouse as demais diluições e então, realizou-se a inoculação de $0,1 \mathrm{~mL}$ de cada diluição 
selecionada sobre a superfície seca do ágar Baird-Parker. Com o auxílio de alça de Drigalski espalhou-se o inóculo cuidadosamente por toda a superfície do meio, em placas, até sua completa absorção. Foram realizadas duplicatas de cada diluição. As placas foram invertidas e incubadas a $36 \pm 1^{\circ} \mathrm{C}$ por 30 a 48 horas. Selecionou-se as placas que continham entre 20 e 200 colônias, fez-se a contagem das colônias típicas (T) e atípicas (A), selecionando 3 a 5 colônias de cada tipo (T) e/ou (A). Semeou-se cada uma das colônias selecionadas em tubos contendo $\mathrm{BHI}$ e incubou-se a $36 \pm 1^{\circ} \mathrm{C}$, por 24 horas. Para o teste de confirmação foram transferidos $0,2 \mathrm{~mL}$ desta cultura em tubos estéreis e adicionou-se $0,5 \mathrm{~mL}$ de Coagulo Plasma - EDTA, misturou-se com movimentos de rotação suaves e incubou-os a 35-37 C, durante 6 horas. Após este período, os tubos que apresentaram a formação de coágulos foram considerados positivos. Para a obtenção do número final de UFC. $\mathrm{g}^{-1}$ utilizou-se a seguinte fórmula:

UFC. $\mathrm{g}^{-1}=\mathrm{n} \times \mathrm{d} \times 10 \mathrm{xp}$

Onde; $\mathbf{n}=$ número de colônias típicas nas placas do ágar Baird-Parker; $\mathbf{d =}$ diluição inoculada na referida placa (por exemplo; na diluição $10^{-3}=1000$ ); $\mathbf{1 0 =}$ refere-se a quantidade de inóculo utilizado na placa do ágar Baird-Parker (neste estudo $0,1 \mathrm{~mL}) ; \mathbf{p}=$ porcentagem do total de colônias testadas que apresentaram coagulase positiva.

\subsubsection{Salmonella $s p$}

Para a pesquisa de Salmonella foram utilizadas $25 \mathrm{~g}$ de camarão in natura adicionadas de $225 \mathrm{~mL}$ de solução salina peptonada $1 \%$ tamponada. Homogeneizouse por aproximadamente 60 segundos em "stomacher" e ficou por 1 hora em temperatura ambiente. Após o pré-enriquecimento fez-se a inoculação em meios 
seletivos (caldos Rappaport Vassiliadis, selenito cistina e tetrationato). A partir dos caldos de enriquecimento seletivo repicou-se sobre a superfície de placas, previamente secas, estriando-as de forma a se obter colônias isoladas em cada um dos meios sólidos seletivos. Dessa forma, foram obtidas 3 placas de BPLS, originárias dos caldos Rappaport Vassiliadis, caldo selenito cistina e caldo tetrationato, respectivamente. Todas as placas foram incubadas invertidas, a $36 \pm 1^{\circ} \mathrm{C}$, por 18 a 24 horas. Selecionou-se de 3 a 10 colônias suspeitas por amostra e estas foram repicadas em ágar não seletivo e incubadas a $36 \pm 1^{\circ} \mathrm{C}$, por 18 a 24 horas, para verificar sua pureza, seguindo-se com as provas bioquímicas. $\mathrm{O}$ resultado foi considerado positivo para Salmonella quando as culturas apresentavam reações típicas nas provas bioquímicas e reação sorológica positiva frente ao anti-soro polivalente “O”, conforme exposto em Brasil (2003).

\subsubsection{Contagem de coliformes totais e termotolerantes}

Para a contagem de coliformes totais pesou-se, assepticamente, $25 \mathrm{~g}$ de camarão sete-barbas in natura, aos quais foram adicionados $225 \mathrm{~mL}$ de solução salina peptonada $0,1 \%$. Homogeneizou-se por aproximadamente 60 segundos em “stomacher", obtendo-se a diluição $10^{-1}$. As diluições foram inoculadas em ágar cristal violeta vermelho neutro bile (VRBA) e incubadas a $36 \pm 1^{\circ} \mathrm{C}$ por 24 a 48 horas, para posterior contagem das colônias suspeitas. A presença de coliformes totais foi confirmada pela formação de gás (mínimo 1/10 do volume total do tubo de Durhan) ou efervescência quando agitado gentilmente. O resultado obtido para cada colônia, bem como a diluição utilizada foram anotados. A leitura foi realizada após 24 horas de incubação e apenas foram considerados válidos os resultados positivos. Os tubos que apresentaram resultado negativo eram incubados por mais 24 horas.

A contagem dos coliformes termotolerantes foi realizada a partir da inoculação das culturas suspeitas de coliformes termotolerantes em tubos contendo caldo EC $\left(\sim 45^{\circ} \mathrm{C}\right)$ em banho maria com agitação, por 24 a 48 horas. A presença de 
coliformes termotolerantes foi confirmada pela formação de gás (mínimo 1/10 do volume total do tubo de Durhan) ou efervescência quando agitado gentilmente. O resultado obtido para cada colônia, bem como, a diluição utilizada foram anotados. A leitura foi realizada após 24 horas de incubação e apenas foram considerados os resultados positivos. Os tubos que apresentaram resultado negativo foram incubados por mais 24 horas (BRASIL, 2003).

\subsubsection{Bolores e Leveduras}

Pesou-se, assepticamente, $25 \mathrm{~g}$ do camarão sete-barbas em sacos para "stomacher" e adicionou-se $225 \mathrm{~mL}$ de solução salina peptonada $0,1 \%$. A partir da

diluição inicial $10^{-1}$, efetuaram-se as demais diluições, até $10^{-3}$. A seguir, inoculou-se 0,1 mL de cada diluição sobre a superfície seca de ágar batata glicose $2 \%$ acidificado a pH 3,5 (com 1,5 mL de solução de ácido tartárico $10 \% .100 \mathrm{~mL}^{-1}$ ) e com o auxílio de uma alça de Drigalski espalhou-se o inóculo cuidadosamente por toda a superfície do meio, até sua completa absorção. As placas foram incubadas, sem inverter, a $25^{\circ} \mathrm{C}$ por 5 a 7 dias, em incubadora de B.O.D. As placas que continham entre 15 e 150 colônias foram selecionadas. A partir dos dados obtidos, calculou-se o número de microrganismos presentes levando-se em conta o número de colônias e a diluição e os resultados foram expressos em UFC. $\mathrm{g}^{-1}$ (BRASIL, 2003).

7.2.4.5 Microrganismos aeróbios mesófilos

As contagens de bactérias mesófilas foram realizadas segundo Morton (2001), onde 25 g de camarão in natura foram pesadas assepticamente e acrescidas 
de $225 \mathrm{~mL}$ de solução salina 0,85\%. Homogeneizou-se por aproximadamente 60 segundos em "stomacher", obtendo-se a diluição $10^{-1} \mathrm{e}$, a partir desta, realizou-se diluições seriadas até $10^{-4}$. Adicionou-se $1 \mathrm{~mL}$ de cada diluição em placas de Petri contendo aproximados $20 \mathrm{~mL}$ de PCA, fundido a $45^{\circ} \mathrm{C}$ e, após homogeneização e solidificação do ágar, as placas foram incubadas a $37^{\circ} \mathrm{C}$ por 48 horas. Os resultados foram obtidos multiplicando-se o número de colônias pelo fator de diluição e expressos em UFC. $\mathrm{g}^{-1}$.

\subsubsection{Microrganismos aeróbios psicrotróficos}

As contagens de microrganismos psicrotróficos foram realizadas segundo Cousin, Jay e Vasavada (2001). Pesou-se 25 g, assepticamente, de camarão in natura e adicionou-se $225 \mathrm{~mL}$ de solução salina $0,85 \%$, homogeneizando por aproximadamente 60 segundos em "stomacher", obtendo-se assim a diluição $10^{-1} 1 \mathrm{e}$ então, a partir desta realizou-se diluições seriadas até $10^{-4}$. O volume de $0,1 \mathrm{~mL}$ de cada diluição foi semeado na superfície de placas de Petri contendo ágar padrão para contagem (PCA) com o auxílio de uma alça de Drigalski. A seguir, as placas foram incubadas a $7 \pm 2^{\circ} \mathrm{C}$ por 10 dias. Os resultados foram obtidos multiplicando-se o número de colônias pelo fator de diluição e expressos em UFC. $\mathrm{g}^{-1}$. 


\subsubsection{ANÁLISE SENSORIAL E DESENVOLVIMENTO DO PROTOCOLO PRELIMINAR}

O treinamento dos julgadores para a análise sensorial dos camarões e a análise, propriamente dita, seguiu a proposta do Codex Alimentarius (2001). Concomitantemente, realizou-se a elaboração do protocolo de análise sensorial QIM para o camarão Xiphopenaeus kroyeri, com base nas metodologias descritas por Martinsdóttir et al., (2001) e Cardenas Bonilla; Sveinsdottir; Martinsdottir, (2007). Diariamente, 2 pesquisadores observaram o camarão sete-barbas armazenado em gelo, desde a captura (dia 0) até a sua total rejeição sensorial. Com base nas observações diárias foram descritos os parâmetros sensoriais significantes para a espécie em questão. Cada parâmetro recebeu um escore de 0 a 3, referente aos seus descritores, onde o escore 0 corresponde ao camarão muito fresco. Os escores aumentaram de acordo com a deterioração do mesmo até um máximo de 3 para cada parâmetro. Então, um protocolo preliminar para a avaliação do camarão sete-barbas inteiro armazenado em gelo foi elaborado.

A partir da elaboração do protocolo preliminar, realizou-se 7 sessões de treinamento, para 10 a 12 julgadores, onde 5 peças de camarão sete-barbas in natura inteiros eram avaliadas por cada julgador utilizando-se o protocolo preliminar. $\mathrm{Na}$ primeira sessão houve a apresentação de camarões com diferentes tempos de estocagem, bem como, uma exposição, realizada por um especialista em crustáceos, sobre as características típicas da espécie alvo. O líder dos julgadores explicou como utilizar o protocolo e como avaliar cada parâmetro e o painel de julgadores podia fazer questionamentos e sugestões. Após cada sessão os julgadores discutiam a adequação do protocolo e o líder fazia as adequações sugeridas. Os julgadores eram notificados das alterações realizadas nas sessões subsequentes e após a última sessão o protocolo estava completo (Figura 17). Todas as sessões de avaliação sensorial foram realizadas em sala específica, com a área de preparação das amostras 
fisicamente separada da área de avaliação, equipada com ar condicionado e gabinetes para provas individuais com lâmpada fluorescente, de luz branca.

\begin{tabular}{llc}
\hline PARAMETROS & DESCRITORES & PONTOS DE DEMÉRITO \\
\hline Odor & Fresco, suave a algas marinhas & 0 \\
& Fraco de maresia & 1 \\
& Levemente amoniacal e frutado & 2 \\
& Amoniacal forte, pútrido & 3 \\
\hline Cor & Cinza translúcido & 0 \\
& Cinza, levemente rosado/ alaranjado no & 1 \\
& dorso & 2 \\
\hline Melanose & Cinza amarelado escurecido/ esverdeado & 0 \\
& Ausência de melanose & 1 \\
& Presença na cabeça & 2 \\
\hline Aderência do cefalotórax ao corpo & Fresença na cabeça e corpo & 0 \\
& Aderência média & 1 \\
& Aderência fraca & 2 \\
\hline Aderência da carapaça & Fortemente aderida & 0 \\
& Aderência média & 1 \\
\hline ÍNDICE DE QUALIDADE: $0-11$ Pontos de demérito & 2 \\
\hline
\end{tabular}

Figura 17. Protocolo de avaliação do frescor do camarão Xiphopenaeus kroyeri armazenado em gelo

\subsubsection{VERIFICAÇÃO DA VIDA ÚTIL E OTIMIZAÇÃO DO PROTOCOLO QIM PARA O CAMARÃO MARINHO Xiphopenaeus kroyeri INTEIRO, ESTOCADO EM GELO}

Foram conduzidos quatro ensaios de vida útil do camarão sete-barbas (Xiphopenaeus kroyeri) in natura armazenado em gelo, com e sem sulfito, nos quais 5-7 julgadores previamente treinados avaliaram sensorialmente os camarões nos diferentes tempos de estocagem até a sua rejeição. Todas as sessões de avaliação sensorial foram realizadas em sala específica, com a área de preparação das amostras fisicamente separada da área de avaliação, equipada com ar condicionado e gabinetes para provas individuais com lâmpada fluorescente, de luz branca. O primeiro ensaio 
de vida útil utilizou o protocolo desenvolvido durante a fase inicial do estudo (protocolo preliminar) e os 3 ensaios subsequentes o protocolo final (Figura 17). A alteração do protocolo inicial proposto se deu devido a dificuldade do painel de julgadores na determinação da coloração do camarão e a grande variação da mesma em função de diversos fatores (habitat, período reprodutivo, estado nutricional, entre outros). Então, o painel sugeriu o acréscimo de 1 descritor para este parâmetro, somando-se 1 ponto de demérito ao protocolo inicialmente proposto. Assim, no primeiro ensaio (novembro/2011) o protocolo foi ajustado e os julgadores calibrados e os ensaios adicionais (fevereiro/2012; julho/2012 e agosto/2012) foram considerados para a validação do protocolo (Figura 17).

Para cada período do estudo de vida útil, cada provador avaliou sensorialmente 5-7 peças de camarão do "controle" e 5-7 peças de camarão tratadas com sulfito. As amostras in natura codificadas foram apresentadas separadamente ao painel de julgadores, acompanhadas do protocolo QIM (Figura 17). Sequencialmente, as amostras foram acondicionadas em embalagens de alumínio, cozidas ao vapor $\left(70^{\circ} \mathrm{C}\right.$, por $3 \mathrm{~min}$.), codificadas e então oferecidas ao painel. Para a avaliação sensorial descritiva do camarão cozido utilizou-se uma escala numérica de 5 pontos (Anexo 4). A verificação da vida útil do camarão in natura estocado em gelo, com e sem adição de sulfitos, foi realizada concomitantemente, por meio das determinações física e químicas na matéria-prima quanto aos parâmetros de BNVT, TMA pH e aminas biogênicas. Além disso, foram realizadas as análises microbiológicas contempladas pela ANVISA (Brasil, 2001), sendo elas S. aureus, Salmonella spp e ainda, as contagens de coliformes totais, bolores e leveduras, contagens padrão de bactérias heterotróficas aeróbias mesófilas e psicrotróficas. Cabe informar que o estudo de vida útil iniciou-se um dia após a captura dos camarões, portanto considera-se Dia 0, o dia da captura e Dia 1, o dia após a captura, quando foram iniciadas as análises laboratoriais. Este trabalho foi avaliado pelo Comitê de Ética em Pesquisa da Faculdade de Saúde Pública da Universidade de São Paulo (COEP) e aprovado de acordo com os requisitos da Resolução CNS/196/96 do Conselho Nacional de Saúde (Anexo 5). 


\subsubsection{ANÁLISE ESTATÍSTICA}

Os resultados obtidos nos ensaios de vida útil foram tabulados em Excel, analisados com auxílio do programa STATA 8.0 (StatSoft Inc., USA) e expressos como média e desvio padrão. Os valores médios de todos os parâmetros estudados foram plotados, separadamente, em função do período de armazenamento em gelo. $\mathrm{O}$ modelo de Regressão Linear Simples foi empregado para a análise dos dados e os modelos de calibração foram calculados para cada ensaio, utilizando-se o Índice de Qualidade (IQ) médio para cada dia de estocagem em gelo (CARDENAS BONILLA; SVEINSDOTTIR; MARTINSDOTTIR, 2007). 


\section{3 RESULTADOS E DISCUSSÃO}

7.3.1 Valor do $\mathrm{pH}$

Os valores de $\mathrm{pH}$ para os 4 lotes de camarão sete-barbas apresentaram-se acima do limite indicado pela legislação nacional para a qualificação do pescado para o consumo (BRASIL, 1952) já no primeiro dia do experimento (Dia 1).

Gonçalves e Junior (2009) também obtiveram pH elevado $(9,10$ e 9,27) para o camarão sete-barbas no tempo zero do armazenamento sob congelamento.

O valor médio do $\mathrm{pH}$ muscular no Dia 1 foi 7,59 $\pm 0,09$ para os camarões do controle e 7,63 \pm 0,05 para os camarões tratados com sulfito.

Os valores de $\mathrm{pH}$ do músculo dos camarões aumentaram significativamente $(\mathrm{p}<0,05)$ durante o período de armazenamento em gelo, tanto para o controle quanto para os camarões tratados com sulfito (Figura 18).

Zeng, Thorarinsdottir e Olafsdottir, (2005) observaram um rápido aumento do pH de camarões Pandalus borealis armazenados em gelo a $1,5^{\circ} \mathrm{C}$. Leitão e Rios (2000) também verificaram a elevação do pH do camarão Macrobrachium rosembergii sob refrigeração $\left(0\right.$ e $\left.5^{\circ} \mathrm{C}\right)$.

$\mathrm{O}$ aumento do $\mathrm{pH}$ pode indicar o acúmulo de compostos alcalinos, como a amônia, formada principalmente pela ação bacteriana (OKEYO; LOKURUKA; MATOFARI, 2009), ou ainda, o aumento das BNVT, resultante da decomposição dos compostos nitrogenados por enzimas endógenas e/ou de microrganismos. 

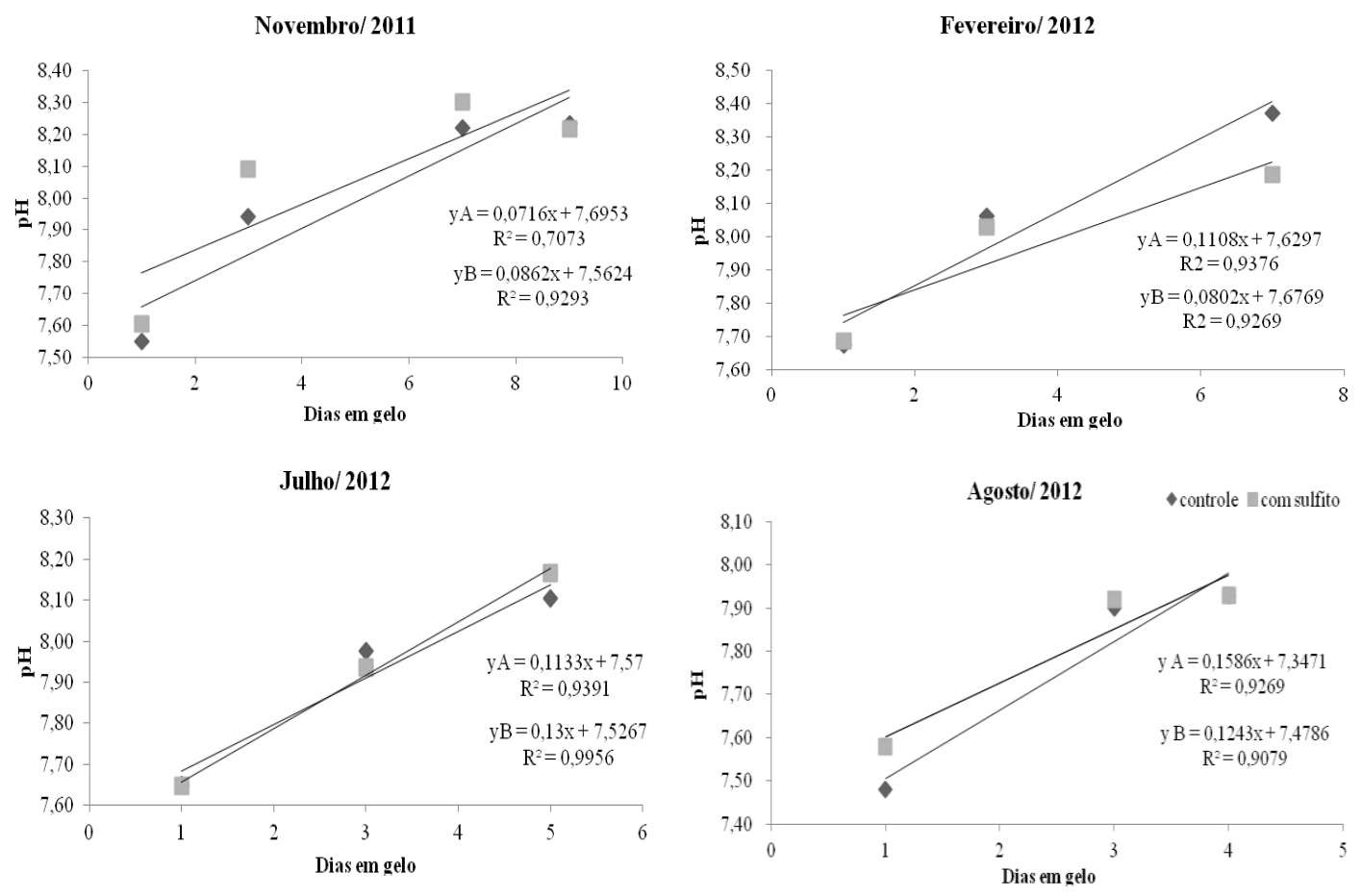

Figura 18. Variação dos valores de $\mathrm{pH}$ de camarões sete-barbas durante armazenamento em gelo $(\mathrm{A}=$ controle; $\mathrm{B}=$ tratados com metabissulfito de sódio a $1,25 \%)$

A determinação do valor de pH do músculo dos camarões sete-barbas mostrase uma ferramenta prática e promissora na avaliação da qualidade para a espécie armazenada em gelo, como indicam os coeficientes de determinação $\left(\mathrm{R}^{2}\right)$ apresentados na Figura 18. No entanto, como já bastante comentado pela literatura científica, não deve ser utilizada de forma isolada, uma vez que são muitos os fatores que podem afetar os seus valores.

\subsubsection{Bases Nitrogenadas Voláteis Totais}

O valor médio das BVNT no Dia 1 foi de $24 \mathrm{mg} \mathrm{N} 100 \mathrm{~g}^{-1}$, tendo variado de 15,7 a 36,2 mg N.100g ${ }^{-1}$ entre os lotes. O lote de agosto/ 2012 apresentou melhor qualidade e consequente menores valores de BNVT e pH. 
Os lotes de novembro/ 2011 e julho/ 2012 apresentaram teores de BNVT igual e superior, respectivamente, ao limite indicado pelo RIISPOA (BRASIL, 1952) para o pescado adequado ao consumo, já no $1^{\circ}$ dia de armazenamento em gelo. Estes mesmos lotes ainda apresentaram formação de TMA, sendo que para o lote de julho/ 2012 os teores determinados encontraram-se próximo a $4 \mathrm{mg} \mathrm{N}$. $100 \mathrm{~g}^{-1}$ no início de armazenamento em gelo e seus valores aumentaram com o avanço do período, tanto para o controle como para os camarões tratados com sulfito. Os lotes de camarão sete-barbas de fevereiro/2012 e agosto/2012 não apresentaram TMA.

Os valores das BNVT não tiveram aumento durante os primeiros dias de armazenamento sob refrigeração, com tendência a redução nos valores em função do período de armazenamento (Figura 19). A diminuição do teor de BNVT, registrada nos camarões, pode ter ocorrido devido à lixiviação destes compostos com a água de fusão do gelo (HOWGATE, 2010).
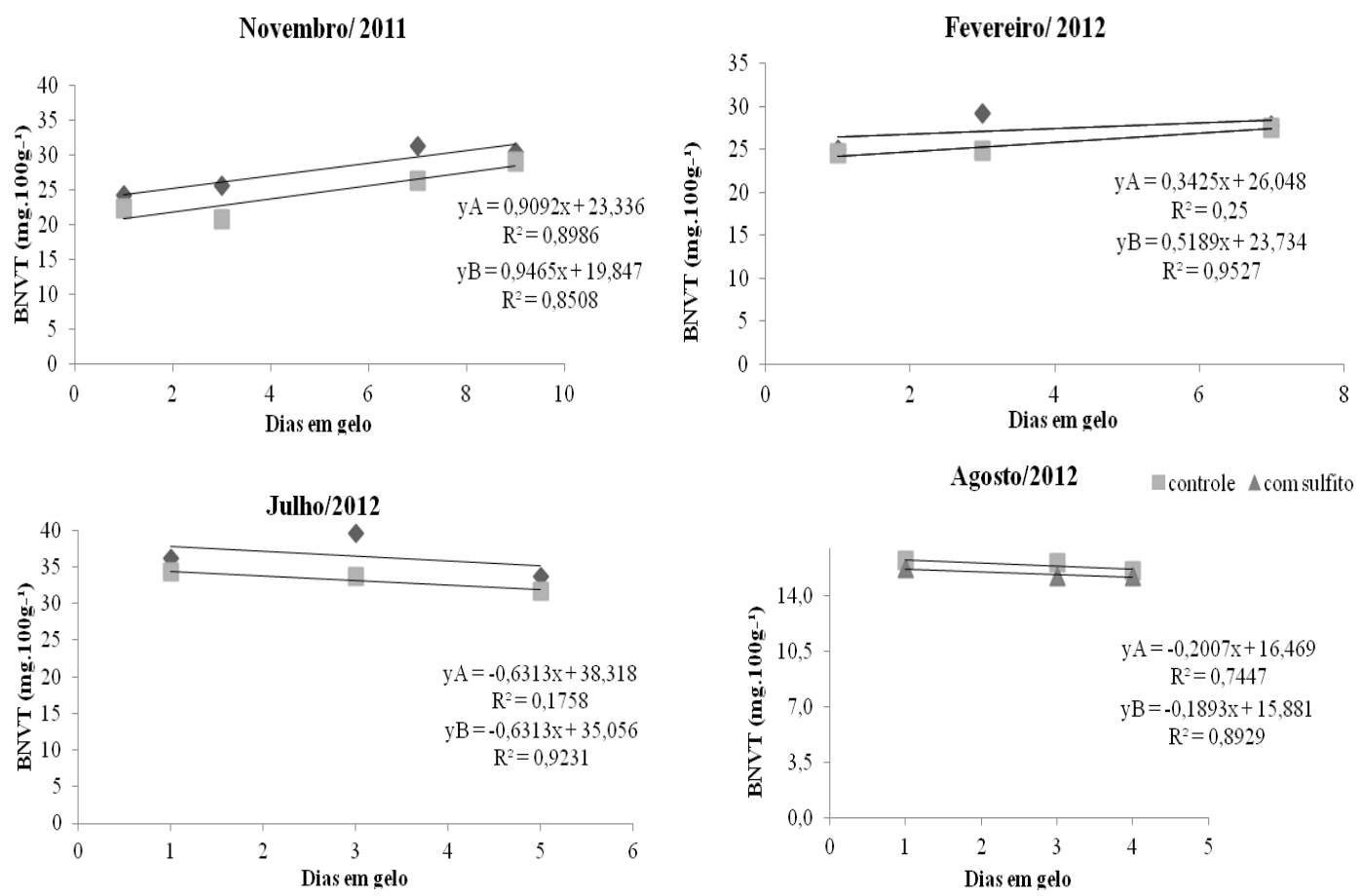

Figura 19. Valores de BNVT em camarões sete-barbas durante armazenamento em gelo $(\mathrm{A}=$ controle $; \mathrm{B}=$ tratados com metabissulfito de sódio a 1,25\%) 
Os valores médios das BNVT para os camarões tratados com sulfito apresentaram correlação com o período de armazenamento em gelo ( $\mathrm{p}<0.05)$. Zeng, Thorarinsdottir e Olafsdottir, (2005) encontraram boa correlação deste parâmetro com a qualidade de camarões.

A regressão linear dos valores médios de BNVT, em função do período de armazenamento em gelo (Figura 19), indica a adequação das BNVT como parâmetro para avaliação do frescor para os camarões sete-barbas tratados com sulfitos; apesar de não ser o índice mais indicado para produtos armazenados diretamente em gelo.

No presente estudo, as BNVT não apresentaram correlação com o período de estocagem em gelo para os camarões do "controle", quando os mesmos já apresentavam teores elevados de BNVT inicialmente, o que ocorreu nos ensaios de fevereiro/ 2012 e julho/ 2012.

\subsubsection{Aminas Biogênicas}

Segundo o Código CAC/RCP 52-2003 do CODEX (2009), a temperatura do pescado deve ser registrada para todos os lotes recebidos e no produto fresco não deve superar $4^{\circ} \mathrm{C}$, sendo necessárias amostragens representativas para se avaliar os possíveis perigos e defeitos.

Frente a provável exposição do pescado às altas temperaturas, que ocorrem normalmente por quase todo o país durante o procedimento da pesca e, com vistas a assegurar a vida útil do camarão sete-barbas in natura conservado em gelo, realizouse a pesquisa das aminas biogênicas.

As aminas biogênicas são mensuráveis, principalmente, durante os últimos estágios de armazenamento sob refrigeração e normalmente, utilizadas como indicadores da qualidade e inocuidade do pescado.

Muitas bactérias deteriorantes do pescado produzem uma ou mais das aminas biogênicas; agmatina, cadaverina, histamina, putrescina, espermidina, espermina, e tiramina. A produção destas aminas em produtos pesqueiros depende da composição 
em aminoácidos livres dos mesmos, variando com a espécie (SÁNCHEZ e CIAPARA, 2003; FAO, 2012c).

Segundo Yamanaka, Shiomi e Kikuchi (1987), a agmatina pode ser um índice adequado para a aferição do frescor de crustáceos e moluscos.

$\mathrm{Na}$ presente pesquisa as aminas biogênicas foram encontradas em níveis abaixo do limite de detecção $\left(<1,25 \mathrm{mg} .100 \mathrm{~g}^{-1}\right)$ e, em alguns poucos casos, com teores reduzidos de cadaverina e/ou histamina e/ou putrescina, provavelmente, devido as baixas contagens de microrganismos deteriorantes.

Os níveis de toxicidade das aminas são difíceis de estabelecer uma vez que dependem de fatores individuais e da presença de outras aminas. A histamina, devido a sua toxicidade, apresenta o limite de $100 \mathrm{mg} . \mathrm{kg}^{-1}$ de alimento (BRASIL, 1997).

Segundo Önal (2007), a putrescina, a cadaverina, a espermina e a espermidina não apresentam efeitos adversos significativos/comprovados, mas estas, além de potenciarem os efeitos da histamina, podem reagir com nitritos e formar nitrosaminas carcinogênicas.

Segundo o documento resultante da reunião de peritos sobre histamina e outras aminas biogênicas em pescado e derivados e os riscos à saúde pública (FAO, 2012), a quantidade de aminas biogênicas produzidas depende do nível de aminoácidos livres presentes, que está relacionada com a espécie de pescado e a quantidade e atividade das enzimas descarboxilase. A quantidade de decarboxilases está relacionada ao número de bactérias que as produzem e transferem ao pescado e, consequentemente, com a multiplicação das mesmas.

Muitos fatores podem afetar o crescimento dos produtores de aminas biogênicas e a temperatura é o principal.

O fato do estudo de vida útil ser conduzido em condições ideais e, portanto, sem quebra da cadeia do frio, pode ter sido determinante para o não aumento das aminas biogênicas formadas nos camarões durante o armazenamento em gelo.

No caso do lote de julho/ 2012, que apresentava-se com qualidade inferior, a histamina foi encontrada em quantidade reduzida $\left(1,4 \mathrm{mg} .100 \mathrm{~g}^{-1}\right)$ já no primeiro dia após a captura, mas não teve aumento dos teores durante o periodo de armazenamento em gelo. 
Benner et al., (2003) demonstraram que a putrescina, em concentrações de 3 $\mathrm{mg} . \mathrm{kg}^{-1}$, muitas vezes, confirma a deterioração sensorial de camarões.

\subsubsection{ANÁLISES MICROBIOLÓGICAS}

Os parâmetros microbiológicos pesquisados apresentaram-se de acordo com os limites de segurança propostos pela legislação nacional ou por normas técnicas para o consumo do pescado, durante todo o período de estudo (SÃO PAULO, 1978; ICMSF, 1986; BRASIL 1997; 2001).

Os microrganismos aeróbios psicrotróficos superaram contagens de $10^{5}$ UFC. $\mathrm{g}^{-1}$ com 5 dias de armazenamento em gelo e apenas no lote de Agosto/ 2012. Estes microrganismos são os mais comuns em alimentos refrigerados e responsáveis pela deterioração destes.

Alguns psicrotróficos podem ser patogênicos, como a Aeromonas hydrophila, algumas cepas de Bacillus cereus, Clostridium botulinum tipo E, B e F, Listeria monocytogenes, Vibrio cholera, Yersinia enterocolitica, entre outros. Algumas cepas de Bacillus cereus e S.aureus têm desenvolvimento reduzido em temperaturas entre 7

a $15^{\circ} \mathrm{C}$, mas podem se multiplicar se houver abuso de temperatura durante a estocagem (COUSIN, JAY e VASAVADA, 2001).

Segundo Chinivasagam et al. (1998), a Pseudomonas fragi é o principal microrganismo deteriorante de camarões tropicais. 


\subsubsection{ANÁLISE SENSORIAL E VERIFICAÇÃO DA VIDA ÚTIL DO CAMARÃO Xiphopenaeus kroyeri INTEIRO ESTOCADO EM GELO}

Visto que, o estudo apresentado no Capítulo 2 pontuou a inadequação dos limites regulados, para os parâmetros físico e químicos (pH, BNVT e TMA), para se qualificar o camarão sete-barbas para o consumo e ainda, frente a realidade do armazenamento em gelo, que promove a lixiviação dos compostos nitrogenados (BNVT e TMA); a vida útil dos camarões sete-barbas inteiros in natura armazenados em gelo, foi estimada levando-se em consideração as análises sensoriais, microbiológicas e a pesquisa de aminas biogênicas.

Uma vez que a pesquisa das aminas biogênicas não indicou limitação para o período de estudo e os ensaios microbiológicos apresentaram contagens satisfatórias até o Dia 5 do armazenamento em gelo, o fator determinante na estimativa da vida útil do camarão sete-barbas inteiro foi a rejeição sensorial do produto cozido.

A rejeição do produto sem sulfito foi precoce, pelo escurecimento do cefalotórax do camarão (melanose) no $2^{\circ}$ dia de armazenamento em gelo, tanto do produto cru como cozido, já que os camarões foram sempre analisados inteiros. Certamente a retirada do cefalotórax favoreceria a aceitação dos mesmos por um período superior.

Para os camarões tratados com sulfito a rejeição ocorreu com 3 ou 4 dias, em função da qualidade inicial do lote e foi determinada pela presença de odores não característicos (amoniacal, ácido e/ou sulfídrico) no camarão cozido, os quais apresentaram correlação com o período de armazenamento em gelo ( $\mathrm{r}=0,70 ; \mathrm{p}<$ 0,05), como mostra a Figura 20. 


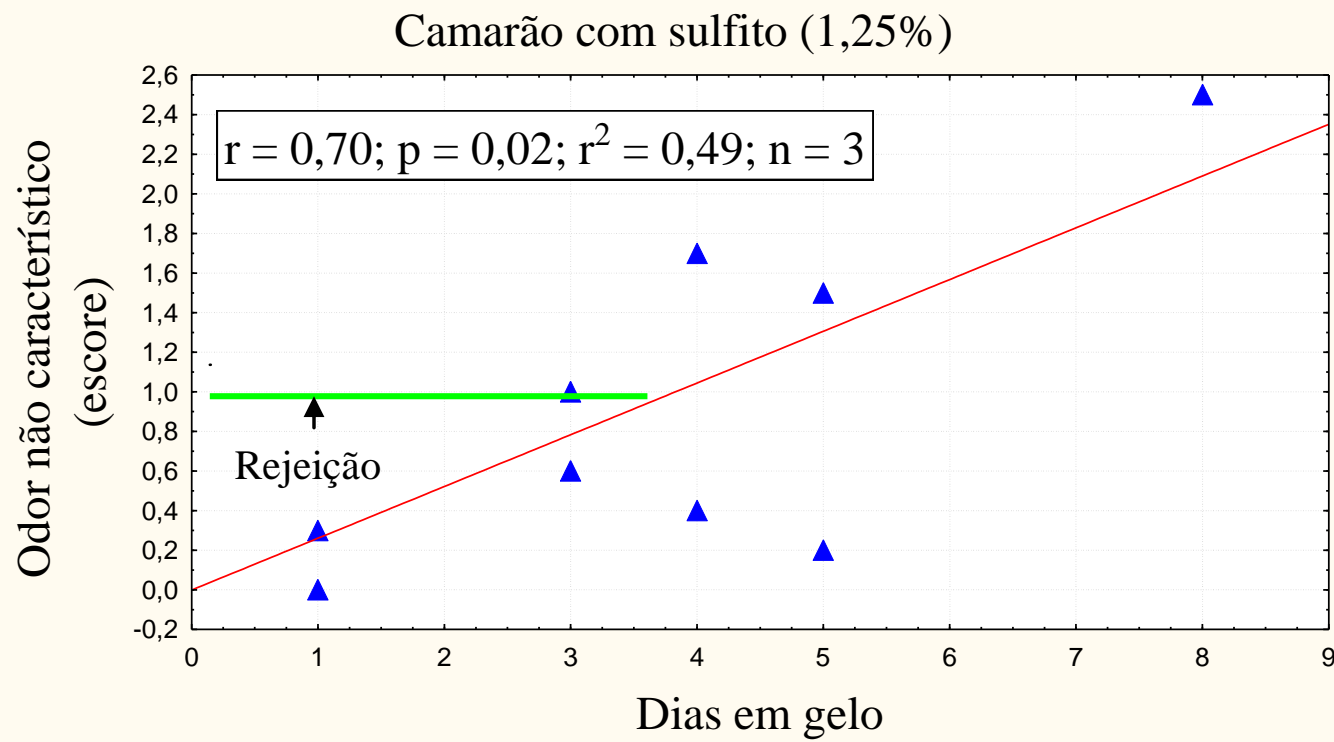

Figura 20. Valores médios do parâmetro odor não característico (amoniacal, ácido e/ou sulfídrico) detectado no camarão sete-barbas com sulfito, durante o armazenamento em gelo.

A avaliação sensorial do produto com sulfito cozido detectou um leve sabor residual amargo, no $3^{\circ}$ ou $4^{\circ}$ dia de armazenamento em gelo, também dependente da qualidade inicial do lote. O sabor amargo residual também foi pontuado no estudo realizado por Neil (2012), com lagostas.

A reduzida vida útil para os camarões sete-barbas da presente pesquisa pode ser reflexo da deficiente classificação a bordo, que incorreu em lotes bastante heterogêneos e camarões de tamanho mínimo, que segundo os resultados obtidos no estudo apresentado no Capítulo 2 estão associados a uma vida útil mais restrita.

Shamshad et al., (1990), já haviam apontado o efeito negativo da manipulação e de temperaturas elevadas sobre a qualidade de camarões, bem como, a drástica redução na sua vida útil.

Hanpongkittikun, Siripongvutikorn e Cohen, (1995) verificaram que camarões Penaeus monodon capturados em condições controladas atingem uma vida útil de 8 dias, enquanto os obtidos por intermediários chegam a apenas 4 dias.

Portanto, a adequada classificação dos camarões e a retirada de sujidades, ainda a bordo, pode garantir uma qualidade superior para o produto desembarcado na região de estudo, trazendo ganhos de até 2 dias na sua vida comercial útil. 
Constatando-se que, devido a restrita vida comercial, para a produção de camarões sete-barbas com elevada qualidade é eminente a definição de padrões, uso de gelo e boas práticas de manipulação a bordo, bem como, uso de conservantes e/ou tecnologias para a preservação.

A partir dos dados obtidos nos ensaios de vida útil do presente estudo, podese indicar que camarões sete-barbas com $\mathrm{pH}<8$ e BNVT $<35 \mathrm{mg} \mathrm{N} .100 \mathrm{~g}^{-1}$, respectivamente, apresentam qualidade aceitável.

\subsubsection{OTIMIZAÇÃO DO PROTOCOLO QIM PARA O CAMARÃO Xiphopenaeus kroyeri INTEIRO ARMAZENADO EM GELO}

A otimização de um protocolo de análise sensorial pelo método QIM leva em consideração a evolução das alterações sensoriais. Após o estabelecimento das mesmas, a definição do ponto de rejeição é dada pela avaliação sensorial do produto cozido (NUNES e BATISTA, 2009).

No caso do camarão sete-barbas a rejeição do produto in natura muitas vezes é anterior a do produto cozido, devido a rápida alteração na sua coloração, principalmente, pelo escurecimento da cabeça (melanose), levando a rejeição precoce do produto cru, mas não do cozido, quando descabeçado, uma vez que o processo de cocção promove o clareamento e consequentemente, a uma melhor aceitação.

Como apresentado anteriormente, a rejeição do produto sem sulfito ocorreu primeiro, pelo escurecimento do cefalotórax do camarão no $2^{\circ}$ dia de armazenamento em gelo, tanto do produto cru quanto cozido, uma vez que os camarões foram sempre analisados inteiros. Para os camarões tratados com sulfito, a rejeição foi determinada pela presença de odores não característicos no camarão cozido e ocorreu com 3 a 4 dias, em função da qualidade inicial do lote (Figura 20).

A evolução das alterações sensoriais foi analisada pela regressão linear simples entre os valores médios obtidos para os parâmetros sensoriais propostos no 
esquema QIM desenvolvido para o camarão sete-barbas (cor, odor, melanose, aderência do cefalotórax ao corpo e aderência da carapaça) e o período de estocagem em gelo.

As correlações entre os parâmetros sensoriais dos ensaios de fevereiro/2012, julho/2012 e agosto/2012, com o período de estocagem em gelo, tanto para os camarões do controle como para os tratados com sulfito, encontram-se ilustradas nas Figuras 21 e 22, respectivamente.
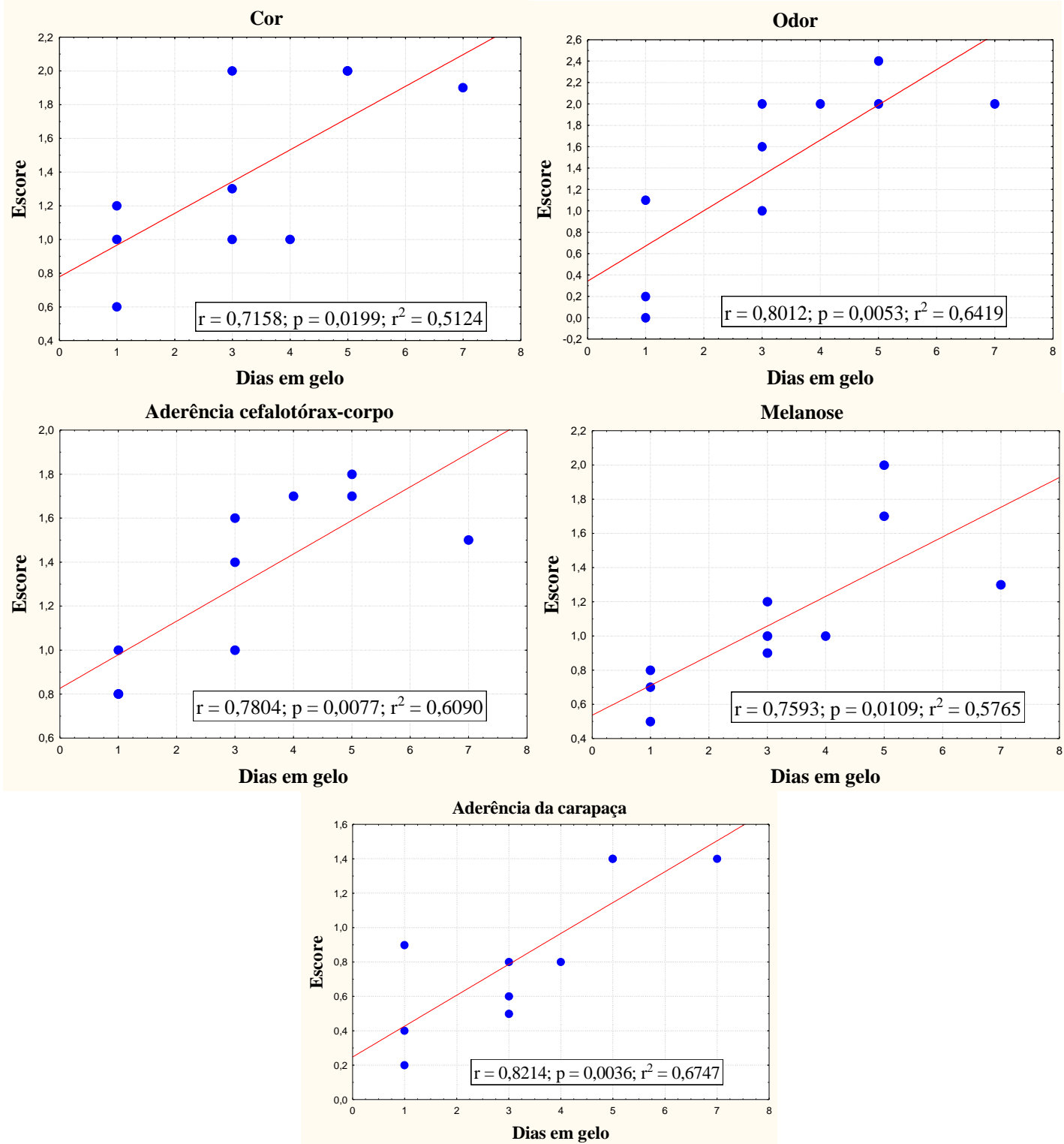

Figura 21. Regressão linear entre os valores médios dos parâmetros sensoriais (escore) e o período de armazenamento em gelo do camarão sete-barbas sem sulfito, referentes a 3 ensaios independentes (fevereiro/2012, julho/2012 e agosto/2012, n=3) . 
Os coeficientes de correlação lineares obtidos (r) e apresentados na Figura 21 demonstram a adequação dos parâmetros sensoriais propostos no protocolo QIM para aferir a qualidade do camarão sete-barbas sem sulfito (controle) ao longo do armazenamento em gelo.

Na Figura 22 são apresentados os coeficientes de correlação entre os parâmetros sensoriais do camarão sete-barbas tratado com sulfito $(1,25 \%)$ e o período de armazenamento em gelo.
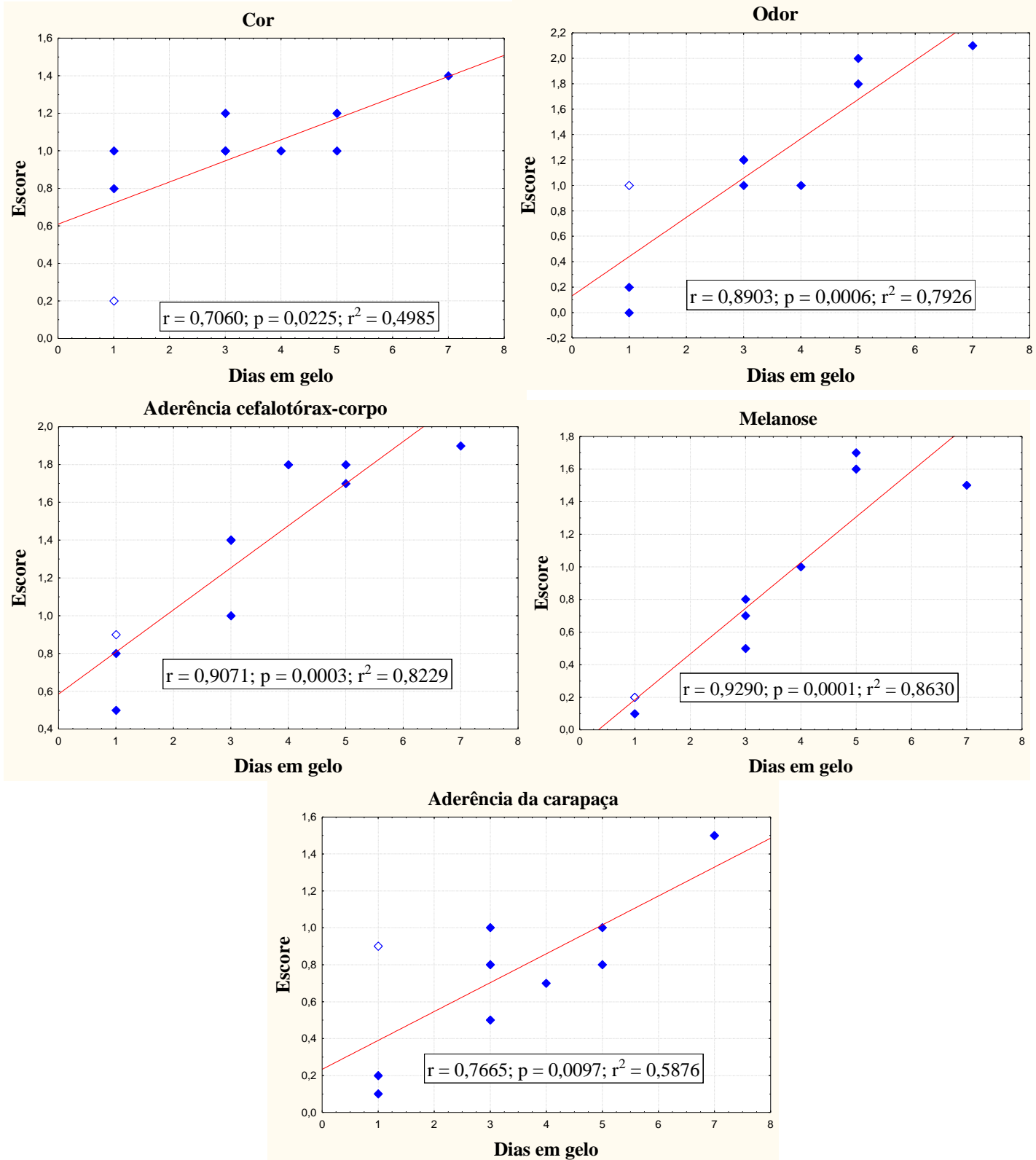

Figura 22. Regressão linear entre os valores médios dos parâmetros sensoriais (escore) e o período de armazenamento em gelo do camarão sete-barbas tratado com sulfito $(1,25 \%)$, referentes a 3 ensaios independentes (fevereiro/2012, julho/2012 e agosto/2012, n=3) . 
Os dados obtidos e apresentados nas Figuras 21 e 22 indicam que o protocolo QIM proposto (Figura 17) mostrou-se adequado à avaliação do frescor do camarão sete-barbas inteiro armazenado em gelo, com e sem o uso de sulfitos.

É possível também observar a dificuldade na avaliação da coloração dos camarões, que refletiu em coeficientes de correlação (r) e de determinação $\left(r^{2}\right)$ menores para este parâmetro, tanto para os camarões tratados com sulfito como para os que não sofreram o tratamento.

Para MEILGAARD (1999), na avaliação sensorial apenas coeficientes de correlação maiores que 0,75 são normalmente considerados. No entanto, a difícil tarefa para um painel sensorial em se determinar a cor é uma realidade para qualquer espécie de pescado, visto que a mesma sofre variação em função de muitos fatores.

A preservação do parâmetro cor no protocolo QIM para o camarão setebarbas é justificável, uma vez que se trata de um parâmetro que caracteriza a espécie, visto que, em muitos locais, a mesma é comercializada como camarão cinza.

O elevado coeficiente de correlação (r) obtido na regressão linear entre o Índice de Qualidade (IQ) e o período de estocagem em gelo, valida o protocolo QIM desenvolvido (Figura 23). Os coeficientes de determinação $\left(\mathrm{r}^{2}\right)$ indicam que o modelo desenvolvido ficou mais ajustado $\left(r^{2}=0,91\right)$ para os camarões tratados com sulfito $(1,25 \%)$.
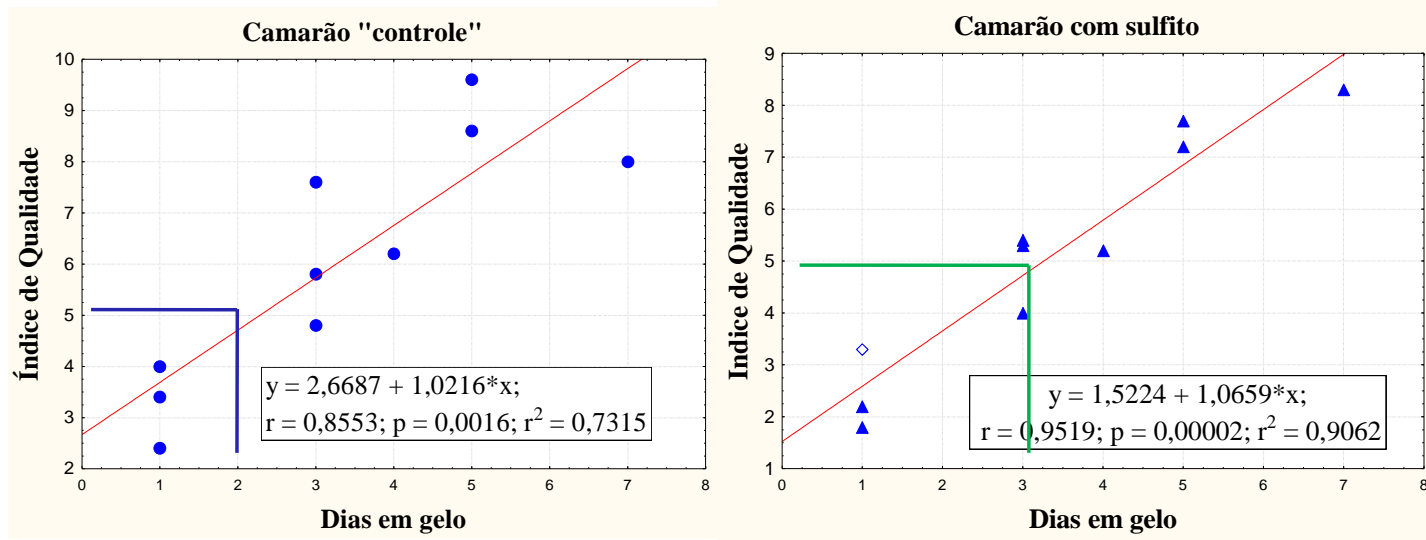

Figura 23. Evolução do Índice de Qualidade do camarão sete-barbas inteiro durante o armazenamento em gelo $\left(2 \pm 2^{\circ} \mathrm{C}\right)$, baseado em três ensaios de vida útil independentes. 
A Figura 23 ilustra ainda que, quando se aplica o QIM para um lote de camarões sete-barbas armazenado em gelo, com ou sem sulfito, o IQ máximo é de 5 pontos de demérito.

Entretanto, um IQ de 5 para camarões tratados com sulfito indica que os mesmos apresentam 3 dias em gelo, enquanto para camarões sem sulfito, este mesmo IQ indica 2 dias de armazenamento em gelo. Acima deste valor o produto não apresentará qualidade. Sendo possível estimar os dias de conservação do camarão sete-barbas em gelo (DIAS) através das fórmulas: IQ = 1,0216* DIAS + 2,6687 e IQ $=1,0659 *$ DIAS $+1,5224$, para camarão sem sulfito e com sulfito $(1,25 \%)$, respectivamente.

De acordo com Gonçalves, Antas e Nunes (2007), o conhecimento dos padrões específicos de deterioração é essencial para melhorar a manipulação do pescado e para se estabelecer critérios de qualidade.

Sendo o valor comercial do pescado associado a sua excelência, que é normalmente avaliada pelo seu frescor; espera-se que o protocolo QIM desenvolvido para o camarão $X$. kroyeri inteiro armazenado em gelo contribua para a valoração da qualidade do camarão sete-barbas produzido no país e, consequentemente, para o desenvolvimento desta cadeia produtiva.

\subsection{CONCLUSÃO}

O protocolo desenvolvido para a avaliação sensorial do frescor do camarão marinho Xiphopenaeus kroyeri inteiro, armazenado em gelo, consiste de 5 parâmetros, a saber: cor, odor, melanose, aderência do cefalotórax ao corpo e aderência da carapaça, bem como, de seus descritores, os quais somam 11 pontos de 
demérito (Figura 17) e que pode ser utilizado em camarões tratados ou não com sulfito.

Os camarões sete-barbas armazenados em gelo apresentaram uma vida útil de 2 dias e o tratamento dos camarões em solução de sulfito $(1,25 \%)$ pode estender a vida útil dos mesmos em 1 dia, nas mesmas condições de armazenamento. Sendo que, os camarões maiores podem ganhar até 2 dias na sua vida útil se, além do uso do conservante, estes forem classificados e manipulados adequadamente a bordo das embarcações.

\subsection{CONSIDERAÇÕES}

O camarão $X$. kroyeri é uma espécie altamente perecível e precisa ser prontamente resfriada, ainda no mar e desembarcada tão breve quanto possível para garantir melhor rendimento e qualidade;

A conservação de camarões pelo uso do gelo é uma tecnologia largamente aceita como prática e economicamente viável. No entanto, recomenda-se a utilização de dispositivos para registro das temperaturas durante todas as etapas de transporte e comercialização dos camarões sete-barbas para a garantia da qualidade e segurança do produto ofertado;

Ademais, ao uso de baixas temperaturas, a restrita vida útil dos camarões sete-barbas exige o uso de novas tecnologias para a preservação da sua qualidade. 


\section{REFERÊNCIAS}

1. BENNER JR, R.A.; STARUSZKIEWICZ, W.F.; ROGERS, P.L.; OTWELL, W.S. Evaluation of putrescine, cadaverine, and indole as chemical indicators of decomposition in Penaeid shrimp. JFS Food Chemistry and Toxicology, v.68, n.7, p.2178-2185, 2003.

2. BRASIL. Ministério da Agricultura. Regulamento de Inspeção Industrial e Sanitária de Produtos de Origem Animal (R.I.I.S.P.O.A). Decreto n ${ }^{\circ} 30.691$, de 29 de março de 1952. Seção 1, Capítulo 7 - Pescados e Derivados. Diário Oficial da União, Brasília, DF. jul.1952. p.71-73.

3. BRASIL. Ministério da Saúde. Agência Nacional da Vigilância Sanitária. Resolução Comissão Nacional de Normas e Padrões para Alimentos - CNNPA n 14, Brasília, DF. jul. 1977.

4. BRASIL. Ministério da Agricultura. Secretaria Nacional de Defesa Agropecuária. Laboratório Nacional de Referência Animal. Métodos analíticos oficiais para controle de produtos de origem animal e seus ingredientes: II Métodos físicos e químicos. Brasília, DF. 1981.

5. BRASIL. Ministério da Agricultura, Pecuária e do Abastecimento. Regulamento técnico de identidade e qualidade de peixe fresco (inteiro e eviscerado). Portaria $\mathrm{n}^{\circ}$ 185, de 13 de maio de 1997. Brasília, DF. 1997.

6. BRASIL. Ministério da Saúde. Regulamento técnico sobre padrões microbiológicos em alimentos. Agência Nacional da Vigilância Sanitária. Resolução RDC n 12, de 2 de janeiro de 2001.

7. BRASIL. Ministério da Agricultura, Pecuária e do Abastecimento. Métodos analíticos oficiais para análises microbiológicas para controle de produtos de origem animal e água. Secretaria de Defesa Agropecuária. Instrução Normativa n ${ }^{\circ}$ 62, de 26 de agosto de 2003. Diário Oficial da União, Brasília, DF, 2003. Seção 114p.

8. BRASIL. Ministério da Agricultura, Pecuária e Abastecimento. Instrução Normativa $\mathrm{n}^{\circ} 25$, de 2 de junho de 2011. Diário Oficial da União, Brasília, DF, 2011. 
9. BREMNER, H.A. A convenient, easy-to-use system for estimating the quality of chilled seafood. Fish Processing Bulletin, v.7, p.59-70, July.1985.

10. CARDENAS BONILLA, A.; SVEINSDOTTIR, K.; MARTINSDOTTIR, E. Development of Quality Index Method (QIM) scheme for fresh cod (Gadus morhua) fillets and application in shelf life study. Food Control, v.18, n.4, p.352-358, May, 2007.

11. CHINIVASAGAM, H.N.; BREMNER, H.A.; WOOD, A.F.; NOTTINGHAM, S.M. Volatile components associated with bacterial spoilage of tropical prawns. International Journal of Food Microbiology, v.42, p.45-55, 1998.

12. CODEX ALIMENTARIUS. Directrices para la evaluación sensorial del pescado y de los mariscos en laboratorio. Evaluación sensorial del pescado y los mariscos en laboratorio. Volumen 9a , 2001. Sección 4 (CAC/GL 31-1999). p. 131151.

13. CODEX ALIMENTARIUS. Código de prácticas para el pescado y los productos pesqueros. Roma: Organización mundial de la salud. Organización de las naciones unidas para la agricultura y la alimentación (FAO/WHO), 2009. (CAC/RCP 52-2003), 164p.

14. COUSIN, M.A.; JAY, J.M.; VASAVADA, P.C. Psychrotrophic microorganisms. In: DOWENS, F. P.; ITO, K. Compendium of Methods for the Microbiological Examination of foods. 4 ed. Washington: American Public Health Association (APHA), 2001.

15. ESTEVES, E.; ANÍBAL, J. Quality Index Method (QIM): utilização da Análise Sensorial para determinação da qualidade do pescado. In: CONGRESSO DO ALGARVE, 13., Racal-Clube, Lagos. ACTAS... Portugal: Centro cultural de Lagos, 2007. p.365-373.

16. FAO. Food and Agriculture Organization of the United Nations. In: Joint FAO/WHO Expert Meeting on the Public Health Risks of Histamine and Other 
Biogenic Amines from Fish and Fishery Products. Rome, Italy Meeting Report. Rome: FAO Headquarters, 2012. 111p.

17. GÓES, L.M.N.B. Uso do metabissulfito de sódio na pós-colheita do camarão marinho Litopenaeus vannamei (Boone, 1931). 2005. 83p. Dissertação (Mestrado em Recursos pesqueiros e Engenharia de pesca), Universidade Federal Rural de Pernambuco, Recife.

18. GONÇALVES, A.C.; ANTAS, S.E.; NUNES, M.L. Freshness and quality criteria of iced farmed senegale sole (Solea senegalensis). Journal of Agricultural and Food Chemistry, v.55, p. 3452-3461, 2007.

19. GONÇALVES, A.A.; JUNIOR, C.S.G.G. The effect of glaze uptake on storage quality of frozen shrimp. Journal of Food Engineering, n.90, p.285-290, 2009.

20. HANPONGKITTIKUN, A.; SIRIPONGVUTIKORN, S., COHEN, D.L. Black Tiger shrimp (Penaeus monodon) quality changes during iced storage. ASEAN Food Journal, v.10, n.4, 1995.

21. HEINITZ, M.L.; RUBLE, R.D.; WAGNER, D.E.; TATINI, S.R. Incidence of Salmonella in fish and seafood. Journal of Food Protection, v.63, n.5, p.79-592, 2000 .

22. HOWGATE, P. A critical review of total volatile bases and Trimethylamine as indices of freshness of fish. Part 2. Formation of the bases, and application in quality assurance. EJEAFChe, v.9, n.1, p. 58-88, 2010.

23. HUIDOBRO, A.; PASTOR, A.; TEJADA, M. Quality index method developed for raw gilthead seabream (Sparus aurata). Journal of Food Science, v.65, n.7, p.1202-1205, 2000. 
24. HUSS, H.H. Quality and quality changes in fresh fish. Rome: FAO, 1995. 195p. (FAO Fisheries Technical Paper 348).

25. HYLDIG, G.; NIELSEN, J. QIM a tool for determination of fish freshness. In: SHAHIDI, F.; SIMPSON, B. K. Seafood Quality and Safety. Advances in the New Millennium. St John’s: ScienceTech Publishing Company, 2004. p. 81-89.

26. ICMSF. International Commission on Microbiological Specification for Foods. Microorganisms in foods. 2-Sampling for microbiological analysis: principles and specific applications. Toronto: University of Toronto Press, 1986.

27. LEITÃO, M.F.F; RIOS, D.P.A. Microbiological and chemical changes in freshwater prawn (Macrobrachium rosembergii) stored under refrigeration. Brazilian Journal of Microbiology, v.31, n..3, 2000.

28. MARTINSDÓTTIR, E.; SVEINSDÓTTIR, K.; LUTEN, J.; SCHELVISSMIT, R.; HYLDIG, G. Sensory evaluation of fish freshness. Reference manual for the fish sector. The Netherlands: QIM Eurofish, 2001. Disponível em: www.qimeurofish.com. Acesso em: 11 Dec. 2011

29. MARTINSDÓTTIR, E.; SVEINSDÓTTIR, K.; LUTEN, J.; SCHELVISSMIT, R.; HYLDIG, G. Development of QIM - past and future. In: LUTEN, J.; OEHLENSCHLAGER, J.; OLAFSDOTTIR, G. Quality of fish from catch to consumer: labelling, monitoring and traceability. The Netherlands: Wageningen Academic Publ, 2003. p. 265-271.

30. MENDES, R. Guidebook on melanosis inhibitors and processing technology of crustaceans. Algés, Lisboa: INIAP/IPIMAR, 2006. Project QLK1CT-2002-71517 (CRUSTAMEL New approaches to the crustaceans prevention of melanosis and quality indices). $41 \mathrm{p}$.

31. MORTON, R.D. Aerobic Plate Count. In: DOWNES, F.P.; ITO, K. Compendium of Methods for the Microbiological Examination of Foods, 4.ed. Washington, DC: American Public Health Association, 2001. 
32. NEIL, D.M. Ensuring crustacean product quality in the post-harvest phase. Journal of Invertebrate Pathology, v.110, n.2, p. 267-275, Jun., 2012.

33. NUNES, M.L.; BATISTA, I. Aplicação do índice de qualidade (QIM) na avaliação da frescura do pescado. Algés, Lisboa: Divulgação IPIMAR, 2004. Disponível em: http://ipimar-iniap.ipimar.pt/servicos/biblioteca/edicoes/ipimardivulgacao/Folheto29.pdf. Acesso em: 20 out. 2009.

34. OKEYO, G.O.; LOKURUKA, M.N.I.; MATOFARI, J.W. Nutritional composition and shelflife of The Lake Victoria Nile Perch (Lates niloticus) stored in ice. African Journal of Food Agriculture Nutrition and Development, v. 9, n. 3, p. 901-919, May, 2009,

35. OMAR, M.I.V Utilization of sodium metabisulphite for preservation of frozen-thawed shrimp (Pandaleus borealis). Final Project 1998, Fisheries Training Programme. Reykjavik, Iceland, 1998. 41p.

36. ÖNAL A. A review: current analytical methods for the determination of biogenic amines in foods. Food Chemistry, v.103, p. 1475-1486, 2007.

37. OTWELL, W.S.; FLICK, Jr.G.J. A HACCP program for raw, cultured Penaeid shrimp. USA: Florida Sea Grant College Program, 1995. p. 218-226. (FLSGP-R-95-001 C3).

38. OTWELL, W.S.; GARRIDO, L.; GARRIDO, V.; BENNER, R. Farm-raised shrimp good aquacultural practices for product quality and safety. Food Science \& Human Nutrition Department and FL Sea Grant College Program. Gainesville: University of Florida, 2001.71p (FL 32611).

39. SHAMSHAD, S.I.; KHER - UN - NISA; RIAZ, M.; ZUBERI, R.; QADRI, R.B. Shelf Life of Shrimp (Penaeus merguiensis) Stored at Different Temperatures. Journal of Food Science, v.55, n.5, p.1201-1205, Aug., 2006.

40. SÁNCHEZ, M.C.C.; CIAPARA, I.H. Manual de Buenas Prácticas de Producción Acuícola de Camarón para la Inocuidad Alimentaria. Descripción de las Buenas Prácticas de Cultivo de Camarón relacionadas con la inocuidad durante el manejo de sustancias químicas y fármacos, 2003. p.45-55. 
41. SÃO PAULO. Decreto $n^{\circ}$ 12.486, de 20 de outubro de 1978. Aprova Normas Técnicas Especiais Relativas a Alimentos e Bebidas, Secretaria do Governo, 20 de outubro de 1978.

42. U.E. Application of melanosis inhibitors by dipping in metabisulphite solution. In: Irish Sea Fisheries Board, Irish South \& West Producers Organization Ltd., Department of the Marine and Natural Resources (Eds.). Whitefish, quality guide. FIFG Project under EU Pesca measure, 2006. 11p.

43. VAZ-PIRES, P. Tecnologia do Pescado, Porto-PT, 2006. 211p. Apostila da disciplina de Tecnologia do Pescado. Instituto de Ciências Biomédicas Abel Salazar - Universidade do Porto.

44. VYNCKE, W. Direct determination of the thiobarbituric acid value in trichloracetic acid extracts of fish as a measure of oxidative rancidity. Fette Seifen Anstrichmittel, v.72, n.12, p. 1084-1087, 1970.

45. YAMANAKA, H.; SHIOMI, K.; KIKUCHI, T. Agmatine as a potential index of freshness of common squid (Todarodes pacificus). Journal of Food Science, v.52, n.4, p.936-938, 1987.

46. YOKOYAMA, V.A. Qualidade do camarão da espécie Xyphopenaeus kroyeri mediante a ação dos agentes antimelanóticos. 2007. 124p. Dissertação (Mestrado em Ciência e Tecnologia de Alimentos) - Departamento de Agroindústria, Alimentos e Nutrição, Escola Superior de Agricultura Luiz de Queiroz, Universidade de São Paulo, Piracicaba, SP.

47. ZENG, Q.Z.; THORARINSDOTTIR, K.A.; OLAFSDOTTIR, G. Quality changes of shrimp (Pandalus borealis) stored under different cooling conditions. Sensory and Nutritive Qualities of Food, v.70, n.7, p. 459-466, 2005. 
Anexo 1- Manuscrito

\title{
VALORAÇÃO DA QUALIDADE DO CAMARÃO SETE-BARBAS (Xiphopenaeus kroyeri) DESEMBARCADO NO LITORAL DE SÃO PAULO, BRASIL
}

\author{
Érika Fabiane FURLAN ${ }^{1}$
}

RESUMO

\begin{abstract}
O setor pesqueiro mantém sua importância em relação à oferta de alimentos e cunmpre importante papel, visto proporcionar mais de $15 \%$ do consumo total de proteina animal. $O$ s crustáceos ocupam o quarto lugar em volume de captura no mundo e o alto valor comercial destes os tornam relevantes em relaģão a montante financeiro gerado pela atividade pesqueira. Atualmente, a garantia da qualidade é requisito para a permanéncia no mercado, sendo exigida dentro de especificacões previamente estabelecidas, tanto pelas autoridades sanitárias brasileiras como dos paises para os quais o pescado é exportado. No caso do camarão marinho, o conceito de qualidade envolve atributos sensoriais, caracteristicas fisicas, quinuicas, biológicas, e ainda as técnicas de captura, processamento, armarenamento, rastreabilidade, apresentação do produto, atenģão da empresa com os aspectos ambientais e contribuigão para o bem estar social. No entanto, a comercialivação de camarốes envolve alguns entraves que afetam sua qualidade, dentre eles, a melanose e o uso abusivo de aditivos são os que trazem maiores prejuiros. A oferta de produtos com qualidade deficiente pode gerar consequências graves à saúde do consumidor. Considerando que o camarão marinho continua sendo o principal responsável pela oferta global do produto e sua importância em termos de divisas seradas pela exportaçäo, existe necessidade de se implementar programas de gestĩo da qualidade deste alimento e para tal, é imprescindivel o desenvolvimento de padröes e/ou resulamentos de qualidade espécie especificos, visto a enormidade de fatores intrinsecos ì espécie na determinação da qualidade.
\end{abstract}

Palavras chave: Inocuidade; sulfitos; crustáceos

\section{QUALITY AGGREGATION OF SETE-BARBAS SHRIMP (Xiphopenaeus kroyeri) DISEMBARKED IN THE COAST OF SÃO PAULO, BRAZIL}

\section{ABSTRACT}

Fishery sector plays an important role in food supply, being responsible for more than $15 \%$ of total animal protein consumed. Crustaceans occupy the fourth place in volume of capture and their high econonic value, make them relevant in the overall financial value senerated by the fichery activity. Nowadays, the guarantee of quality is basic requirement to be kept in market, with established and required specifications either from national sanitary authorities or from countries where fisheries products are exported. In the case of marine shrimp, the concept of quality involves physical chemvical, biological and sensory attributes, and also capture, processing and storage techniques, traceability, product presentation, environmental and social responsibility of the industry. In the shrimp market, amons all difficulties, melanosis and abusive use of additives are the ones who brins more financial and quality loss. The offer of products with poor quality can lead to serious consequences to the consumer's health. Whereas the marine shrimp remains the primary responsibility for slobal supply of the product and its importance in terms of foreign exchange earned by exports, it is needed to develop and to implement a program of quality management for this product, and initially it nust be develop standard and/or regulation of quality specie specific, due to the many intrinsic factors in the specie to determine its quality.

Key words: Food security; sulfite; crustaceans

Artigo de Revisão: Recebido em 28/02/2011 - Aprovado em 09/07/2011

1 Contro APTA do Poscado Marinho, Institu to de Pesca - Unidado Laboratorial do Reforência em Tocnologin do Pescado. An. Bartolomou de Gugmió, 192 - Ponfa da Prain - CEP: 11.030-906 - Santos - SP - Bravil. o-mail: offurlame puscar.op-gov.br Doutoranda em Nutrigaio on Saúdo Pública - Faculdado de Saŕdo Fública da USP 


\section{INTRODUÇÃo}

O mercado brasileiro de pescado constitui um dos setores alimenticios de maior crescimento e desenvolvimento e 0 camarão-sete-barbas (Xiphoponaous kroyori) é a terceira principal espécie marinha desembarcada no Estado de São Paulo (INSTTTUTO DE PESCA, 2011).

Por ser uma espécie costeira, o camarão $X$. kroyori é acessivel à pesca de pequena escala destacando-se entre as espécies marinhas desembarcadas no Estado de São Paulo pela quantidade capturada e pelo número de embarcagóes envolvidas na atividade (SEVERINO-RODRIGUES et al., 1993 (INSTTIUTO DE PESCA, 2011, possuindo, portanto, grande relevância econômica e social (GRAÇA LOPES of al., 2007).

Os camarões são normalmente comercialirado frescos ou congelados. Una vez capturados, estes devem ser imediatamente lavados, classificados por tamanho e pesados. Todo camarão, mesmo se comercializado "in natura", deve passar por um processo de beneficiamento, seja este primário ou integral. $O$ beneficiamento primärio deve ser realizado ainda na embarcação (PINHEIRO e CINTRA, 1999) e o integral deverá ser realizado por uma unidade credenciada pelo Ministério da Agricultura, que obedeça a um sistema de controle da qualidade de Análise de Perigos e Pontos Criticos de Controle - APPCC.

A adoção deste critério é exigência dos mercados internacionais e requer, em suma, a implementação de princípios que objetivam prevenir ou eliminar as condigôes de risco durante a despesca e o processamento dos camarões (NUNES, 2001).

Após a morte de qualquer pescado, as enzimas presentes na carne e visceras passam a atacar as substancias do corpo do pescado. Esta ação, conhecida como autólise, provoca o amolecimento da carne e a produção de odores desagradáveis. Outra consequência deste fenômeno é o aparecimento de manchas pretas (melanose) em lagostas e camarões, preocupante agravante para os paises que exploram tais recursos, dada as grandes perdas de divisas.

A inocuidade dos alimentos representa a principal preocupação das autoridades sanitírias e dos consumidores. Essa preocupação recai, entre outros aspectos, sobre a contaminação por produtos químicos, como a presenga de asrotóxicos, aditivos e antibióticos.

O uso excessivo de sulfitos na prevengão da melanose em camarões, a deficiente qualidade do camarão desembarcado e comercializado no Brasil, bem como o impacto da manipulação inadequada sobre a contaminação de camarōes vem sendo apontados em alguns estudos (THAMPURAN e GOPAKUMAR, 1990; MOURA et al, 2003; OGAWA of al., 2003; YOKOYAMA, 2007; FURLAN e TORRES, 2010; MACHADO of al., 2010).

Aliando estas problemáticas à deficiente fiscalização dos produtos pesqueiros destinados ao mercado interno, bem como a data da legislação vigente para pescado (BRASIL, 1952) e a falta de especificidade da mesma frente a sama de espécies exploradas comercialmente no pais, vê-se a necessidade de desenvolvimento de ferramentas que contribuam para redução dos riscos associados ao consumo do pescado.

- setor pesqueiro brasileiro também apresenta carência por métodos de padronização rápida para avaliação da qualidade do pescado e seus produtos. No Brasil, o principal método utilizado pelas indústrias e servigo de inspeção para a avaliação do frescor em pescado in natura ou de produtos derivados é o sensorial, visto que os demais métodos existentes, fisico-quimicos e microbiológicos, muitas vezes são morosos $\mathrm{e} / \mathrm{ou}$ de alto custo. No entanto, não existe um regulamento técnico de produção, identidade e qualidade para o camarão marinho $X$. kroyori, comprometendo a eficícia desta avaliação.

- que há no País é uma crescente preocupação em aumentar a oferta de alimentos com caracteristicas fisicas, quimicas e microbiológicas satisfatórias, apresentando, assim, maior qualidade e seguranga. Neste contexto, torna-se imprescindivel o estabelecimento de uma metodoloğia eficiente para a avaliação $\mathrm{da}$ qualidade do camarão $\mathrm{X}$. kroyjori, que ofereça informação necessária e de forma simples, viabilizando sua aplicação na rotina dos inspetores e das plantas de processamento.

O "Quality Index Method" (QIM) é um método rápido e tem sido indicado como 
referência na padronização e harmonização da avaliação sensorial de pescado na Europa (MARTINSDÓTTIR ot al., 2001). Segundo alguns autores (BREMNER, 1985; HYLDIG e NIELSEN 1997: NUNES e BATISTA, 2004; ESTEVES ANIBAL, 2007), o QIM tem se mostrado uma ferramenta útil no planejamento da produção e no traballho de garantia da qualidade. Propóe-se, com esta revisão, levantar os principais aspectos da qualidade dos camarões sete-barbas $e$ indicar caminhos para a valoração da mesma, visando a seguranga no consumo desse alimento $e$ a sustentabilidade desta cadeia produtiva.

\section{PRODUÇÃo E MERCADO Do CAMARÃo MARINHO}

A FAO, no documento "The State of World Fisheries and Aquaculture - SOFIA" (FAO, 2008) aponta estabilidade na produção pesqueira mundial nas últimas décadas e indica que a pesca de camarões produz cerca de 3,4 milhões de toneladas ano-1; com aproximadamente $60 \% \mathrm{da}$ produção sendo comercializada no mercado internacional

Durante as duas últimas décadas, o volume total de produtos pesqueiros comercializados intemacionalmente aumentou de 10 milhões para aproximadamente 24 milhões de toneladas métricas (YASUADA e BOWEN, 2006). Apesar do enfraquecimento na demanda no final de 2007 e inicio de 2008, resultante da agitação do setor financeiro e que afetou a confiança do consumidor nos principais mercados, a tendência em lonso prazo para o comércio de pescado é positiva, com aumento parcial tanto em paises desenvolvidos como em desenvolvimento (FAO, 2003).

Atualmente, o camarão é o produto pesqueiro mais importante comercializado no mercado internacional e segundo PAIVA of al., (2004) a atividade extrativa ainda é a principal responsável pela oferta slobal de camarōes $(64,8 \%)$.

No Brasil o mercado de pescado constitui um dos setores alimenticios de maior crescimento desenvolvimento e, no Estado de São Paulo, o camarão-sete-barbas é a terceira principal espécie marinha desembarcada. Os crustáceos representaram $11,8 \%$ do total de pescado desembarcado em $2010 \mathrm{nas}$ cidades de Santos Guaruji. Estes locais receberam $60,2 \%$ da produção em peso de pescado proveniente do extrativismo do Estado (INSTITUTO DE PESCA, 2011).

Globalmente, pouco se conhece quanto 20 número de embarcagóes e pescadores envolvidos na pesca do camarão. Contudo, estatisticas de produção e comércio indicam a importância desta atividade pesqueira e que o camarão sete-barbas encontra-se entre as 10 espécies de camarào mais capturadas em volume no mundo, tendo atingido 52.411 toneladas em 2005 (FAO, 2007).

O camarão é um excelente candidato a fonte de proteina alimentar, dado sua popularidade, alto valor asregado e ter elevada demanda nos mercados dos EUA e EU (HORTON at al, 2008). No entanto, devido sua restrita vida comercial, faz-se imprescindivel adoção das boas práticas de manipulação, processamento e conservação em todos os elos da cadeia produtiva, vislumbrando uma máxima preservação da qualidade e a sarantia de mercado, uma vez que as exigências quanto a qualidade dos produtos pesqueiros é uma questão crescente.

QUALIDADE E REGULAÇÃO NACIONAL para o camarão

Em muitas regiōes do mundo, o pescado fas parte da dieta alimentar e representa, em alguns paises, a principal fonte de proteinas de origem animal. Atualmente, un número cada vez maior de pessoas dí a sua preferéncia ao pescado como uma alternativa saudável ì carne. Contudo, o consumo de pescado pode também causar enfermidades devido ao desenvolvimento de infecgōes ou intoxicagoóes. Algumas dessas doenģas têm sido especificamente associadas ao consumo de pescado, enquanto outras apresentam uma etiologia mais geral (HUSS, 1997).

Conforme exposto, a maior parte do pescado é ainda retirada de uma população selvagem. Assim, a indústria de processamento de pescado marinho no Brasil está limitada, na escollha de suxs matérias primas, ao que está disponivel em termos de tamanho, condiģão e espécies. Neste contexto, o pescador é a pedra fundamental desta cadeia produtiva, pois não existe procedimento posterior a collheita que reconstitua a qualidade inicial da matéria-prima a ser utilisada pelos transformadores. Cabe à instituigões governamentais, indústrias e órgãos de ensino e 
pesquisa aproximarem a comunidade de pescadores dos avangos cientificos e da realidade do comércio slobalizado (YOKOYAMA, 2007).

O pescado pode ser veiculador de uma sama enorme de microrsanismos patogénicos para o homem, a maior parte deles oriunda $\mathrm{da}$ contaminação ambiental Neste sentido, importante destacar as bactérias do sênero Samonolla e as Shigolla spp., todas elas encontradas em águas poluidas por essotos ou excretas animais. No caso particular da pesca maritima, a captura em águas costeiras oferece maiores riscos do que a realizada em alto mar (GERMANO of al., 2008).

Outra fonte importante de contaminação é a manipulação do pescado, desde o momento da captura, ainda nos barcos pesqueiros, até a sua destinação final. Como consequência direta $\mathrm{da}$ manipulação inadequada tem-se apontado os Stroptococcus spp e o Staphylococous aurves, ambos de orisem humana, presentes nas mucosas e superficie da pele, e que encontram no pescado ambiente favorável à sua multiplicação. Inúmeros asentes bacterianos podem ainda contaminar o pescado e causar riscos à saúde.

Poluentes quimicos, biotoxinas endoparasitas são outros riscos associados 20 consumo do pescado. Dentre os poluentes quinicos, o mercúrio assume srande relevância em saúde pública, dado seu efeito cumulativo para o homem, e por, seralmente, estar presente nas águas que recebem efluentes industriais (GERMANO ef al., 2008)

$\mathrm{Os}$ problemas de ordem ambiental, bastante discutidos na atualidade, exercem relação direta sobre a qualidade do pescado. Assim, avangos quanto à certificagão na origem dos produtos pesqueiros são imprescindiveis para a sarantia da seguranģa do consumidor.

Para SCHRÖDER (2008), a intensificação do comércio slobal de alimentos tem direcionado a busca pela sarantia da qualidade, transparência e proteção da saúde do consumidor. $O$ termo "qualidade", com referência aos produtos alimentares, pode ter diversos significados, podendo se referir às caracteristicas sensoriais de um produto, indicar o valor nutricional, o frescor higiene, conveniência, aceitação pelo consumidor e ainda, pode estar associada ì segurança e disponibilidade. No caso do pescado, o frescor assume particular releváncia, pois constitui o primeiro critério para a aceitaçào ou rejeição (NUNES e BATISTA, 2004; ABBAS of al., 2008).

Muitos consumidores sabem que o pescado e muitos de seus produtos derivados são itens alimentares altamente pereciveis, mas poucos conhecem a complexidade desta cadeia produtiva e quão complicada pode ser a trajetória do pescado até o prato do consumidor (SCHRÖDER, 2008).

Informações quanto is técnicas de manipulaçĩo, processamento e estocašem, incluindo histórico de tempo e temperatura, que podem afetar o frescor e qualidade dos produtos. são de grande importância para os agentes desta cadeia produtiva. Adicionalmente, as condigões ambientais, que afetam as äreas de pesca, os métodos de captura e a ocorréncia de defeitos, influenciam diretamente na qualidade seral dos produtos pesqueiros (ABBAS et al., 2008)

$\mathrm{O}$ s processos de autólise ou de perda $\mathrm{da}$ qualidade iniciam-se logo após a morte do pescado. $\mathrm{Em}$ muitos destes processos estão envolvidas substâncias que derivam $\mathrm{da}$ metabolização do nitrogênio. Dentre estas substäncias, hả de se salientar o oxido de trimetilamina (OTMA), que pode ser transformado em trimetilamina (TMA), pela ação bacteriana, ou dimetilamina (DMA) e formaldeido (FA), por ação enzimática (HUSS et al., 2004).

Outra consequéncia do processo deteriorativo é o aparecimento de manchas pretas (melanose) em lagostas e camarões. Substâncias redutoras, tais como sulfitos, ácido ascórbico e cisteina, são usualmente empregadas no controle da melanose (OGAWA e DINIZ, 1999).

Segundo OTWELL e FLICK (1995), os sulfitos têm sido utilizados no controle da melanose em camarões desde meados de 1950 . No entanto, o uso de aditivos químicos em camarões, com o intuito de prevenir a melanose, vem sofrendo restrições, principalmente pelo mercado externo, devido ao abuso e efeitos tóxicos por eles provocados (MORAIS, 1984).

$\mathrm{Os}$ sulfitos sào emprestados ainda a bordo das embarcações e, quando usados em excesso, podem não só causar reaģöes adversas em individuos sensiveis ao dióxido de enxofre, mas também favorecer a decomposição do óxido de 
Valoração da qualidade do camarão sete-barbas (Ẍphoponavus krogyeri)..

trimetilamina ì dimetilamina e a formaldeido, comprometendo a qualidade do produto e do meio ambiente quando seus residuos são descartados sem tratamento adequado.

A utilização deste produto quimico esta amparada na legislação brasileira pela resolução $14 / 77$ da Comissão Nacional de Normas e Padrōes para Alimentos, não devendo o dióxido de enxofre residual ultrapassar $100 \mathrm{mg} \mathrm{kg}^{-1}$ (BRASIL, 1977).

OGAWA e DINIZ (1999) afirmam que o empreso de concentraçöes usuais do bissulfito de sódio dificilmente inibirá a melanose se os espécimes sofreram traumas previamente, o que $i$ de se esperar numa operação de pesca.

Diante do exposto, toma-se perceptivel a necessidade de implantação das Boas Práticas de Manipulação - BPM nas embarcagōes pesqueiras, virando minimizar os impactos netativos sobre a qualidade da matéria-prima, com consequente redução no aporte de preservativos e nos riscos à saúde. $O$ uso excessivo de sulfitos e a deficiente qualidade do pescado desembarcado no Brasil vêm sendo apontados por alsuns autores (OGAWA of al. 2005; YOKOYAMA, 2007; FURLAN e TORRES, 2010; MACHADO ot al., 2010)

$\mathrm{O}$ s sulfitos ingeridos sz̃o oxidados a sulfatos e tiossulfatos por ação enaimaitica, sendo excretados pela urina, não causando risco em niveis normais de uso, para a maioria da população (MACHADO of al., 2006). Porém, alguns estudos indicam casos de sensibilidade à insestão de sulfitos.

No Brasil, o que se sabe é que o indice de camarões danificados pela melanose, denominados "broken" (quebra, do ingles), decresceu na última década (PINHEIRO e CINTRA, 1999). Esta redução da "quebra" pode estar associada ao empreso desordenado destes sulfitos, o que pode estar comprometendo consumo do camarão no mercado interno pelo desenvolvimento de alergias, entre outros sintomas, em consumidores deste pescado.

Grande parte das alteraģóes na qualidade do pescado sz̃o consequência da atividade de microrganismos deteriorantes, como a shewanolle putrofacions, Vibronaceae, Enterobacteriaceae, Photobactorism sp., Halococous sp. e Halobactorimm sp. Segundo HUSS (1995), a deterioração do pescado é acelerada quando a carsa microbiana supera $10^{7}$ UFC $5^{-1}$.

No entanto, a contagem do número de células viáveis é complexa e consome tempo, não sendo um método prático para estimação do frescor. Em contrapartida, a qualidade microbiológica dos alimentos marinhos é um fator chave para a comercialização e na segurança para o consumo.

Alsuns paises, como os Estados Unidos, praticam o monitoramento microbiano das águas de cultivo. No Brasil, não existe ainda um programa de monitoramento das ásuas nas áreas de pesca; o CONAMA, do Ministério do Meio Ambiente, por meio da resolução 357, de 17 de março de 2005, considera que as ásuas para a criação natural e/ou intensiva de espécies destinadas à alimentação humana não devem exceder um limite de 1.000 coliformes termolerantes por $100 \mathrm{~mL}$, em $80 \%$ ou mais de, pelo menos, 6 amostras coletadas durante o período de um ano, com periodicidade bimestral (BRASIL, 2005).

$\mathrm{O}$ s coliformes termolerantes sĩo indicadores especificos e apresentam uma elevada correlação positiva com a contaminação fecal por animais de sangue quente. A enumeração de coliformes totais em água é menos representativa como indicação de contaminação fecal que a enumeração de coliformes termotolerantes ou Escherichin coli. No entanto, sua enumeração é muito utilizada em indústrias alimenticias, indicando poluição présanitização, contaminação pós-sanitização ou pósprocesso, evidenciando práticas de hisiene e sanitização aquém dos padrões requeridos para o processamento de alimentos (PÁDUA, 2003).

No Brasil, a ANV1SA, örgão que regulamenta os padrốes microbiológicos em alimentos, por meio da resolução $\operatorname{RDC} \mathrm{n}^{\circ} 12$, de 2 de janeiro de 2001, preconiea que o camarão in nafura, resfriado ou conselado e que nào será consumido cru, apresente-se livre de Salmonolla sp. em 25 s e limita em $10^{3}$ a contagem de Staphylococous coagulase positiva $5^{-1}$ do pescado (BRAsIL, 2001).

Outros patógenos, tais como, O Clostridism perfringons, o sénero Shigolla, Yorsinia onterocolition, Listaria monocytogenes e Canpylobactor jojuni, representam risco, no entanto, práticas adequadas de manipulação pós captura podem reduzir a frequência de doenças. $O$ risco de infeç̧ões

Bol. Inst. Pascn, São Paulo, 37(3): 317 - 326, 2011 
alimentares associados a estes microorganismos é baixo comparado ao risco de uma infeção viral or por vibrios (EUA, 1992; GERMANO at al., 2008).

Segundo Art. 442 do Resulamento da Inspeção Industrial e Sanitária de Produtos de Origem Animal - R.I.I.P.P.O.A. os crustáceos devem apresentar aspecto brilhante, úmido; corpo em curvatura natural, rígido e com articulos firmes e resistentes; carapaça bem aderente 20 corpo; coloração própria da espécie, sem qualquer pismentação estranha: ollhos vivos, destacados: cheiro próprio e suave (BRASIL, 1952).

Como se pode perceber, os padrões sensoriais disponiveis neste regulamento apresentam-se de forma seneralizada, o que restringe a classificação dos crustáceos aos "experts", uma vez que, num pais rico em diversidade como o Brasil, torna-se dificil $\circ$ conhecimento das caracteristicas particulares às diferentes espécies. Fato este, que limita o trabalho dos técnicos da inspeção, uma vez que os mesmos são responsáveis por fiscalizar uma sama de produtos.

Vale ressaltar que o consumidor moderno está mais exisente quanto ao cumprimento dos requisitos de qualidade por parte das empresas produtoras nos aspectos de sesuranca alimentar, padronizaçào e fraude econômica, além de responsabilidade ambiental e social

No Brasil, os padrões analiticos da qualidade do pescado e derivados estão também baseados na análise de compostos como bases nitrogenadas volíteis totais (N-BVT) e TMA bem como na mensuraģão do $\mathrm{pH}$ e do teor de indol (BRASIL, 1952).

Para BOTTA (1995), estes parâmetros não são capazes de identificar estágios inicizis da perda do frescor, indicando apenas se o produto encontrase deteriorado. Logo, estudos visando o estabelecimento de limites criticos mais adequados são necessírios, devendo monitorar as amostras logo após a captura e ao longo do armazenamento sob condições ideais.

\section{INDICE DE QUALIDADE E VALORAÇÃO DO PESCADO}

Atualmente, com a abertura dos mercados internacionais, processadores devem não somente atender as expectativas nacionais quanto a qualidade, mas também adquirir competitividade no mercado internacional, e a málise sensorial é um dos métodos mais utilizados para sarantir o frescor e a qualidade no setor pesqueiro e pelos servigos de inspeç̃̃o do pescado.

Segundo ABBAS of al. (2008), a avaliação sensorial sempre teve papel fundamental $\mathrm{na}$ análise da qualidade e frescor da indústria pesqueira. As diversas caracteristicas sensoriais, tais como aparência, odor, coloração são ainda muito importantes nos sistemas de qualidade das indústrias processadoras, sendo a inspeção sensorial do pescado processado utilisada na indústria para localizar defeitos ocorridos durante manipulação e processamento.

No entanto, a anallise sensorial tem sido considerada uma metodologia subjetiva, que apesar de apresentar vantagens como baixo custo, rapidez e ter relação direta com os padrões de aceitação do consumidor, exige a participação de um número representativo de julgadores treinados para obtenção de resultados confiáveis e reprodutiveis, o que não é viável na prática. Neste contexto, alternativamente em tempos recentes, alguns autores vêm desenvolvendo o Método do Indice de Qualidade, ou QIM, da designação original em ingles

O QIM foi desenvolvido durante a década de 1980 na "Tasmanian Food Research Unit" (BREMNER, 1985) e baseiz-se na avaliaģ̃o dos atributos sensoriais considerados significativos para o pescado "in natura" (aparência, textura, ollhos, odor, etc.) por meio de um sistema de classificação por pontos de demérito por atributo (de 0 a 3). A soma dessas classificações quantifica a falta de qualidade sensorial até un valor máximo, especifico de cada espécie/sênero, que corresponde à ausência total de qualidade (impróprio para consumo humano) e que se obtém a partir da análise sensorial do pescado por um painel enxuto de julgadores treinados (HUSS, 1995).

A principal diferenca entre o QIM e os outros métodos sensoriais é basear-se em descritores especificos para cada espécie de pescado, o que implica no desenvolvimento e otimiração de um esquema particular para cada umas das espécies de interesse comercial em condiçóes de armazenamento também especificas (BREMNER, 
1987 ; MARTINSDÓTTIR at al., 2001). Em paralelo, a avaliação do pescado coxido é imprescindivel para estabelecer-se a rejeição e estimar a vida útil nas condigões especificas de armazenagem (MARTINSDÓTTIR of al., 2001).

O QIM ja foi desenvolvido para uma gama de espécies de pescado, a saber: European Hake, Chub Mackerel e Horse Mackerel (BADIANI of al. 2009), Sepia officinalis, L (SYKES, et al., 2009), Salvolinus alpinus (CYPRIAN of al, 2008), Gades morhua (BONILLA ot al., 2007), Solon sonogalonsis (GONCALVES of al., 2007), Cholidonichelnys Jucornus (BEKAERT, 2006). Atlantic Halibut (GUILLERM-REGOST et al., 2006), Engrawlis oncrasicholus (PONS-SÁNCHEZ-CASCADO of al. 2006), entre outras. No entanto, nenhum estudo foi realizado com o camarão X. kroyeri.

Segundo MARTINSDÓTTIR et al. (2003), 。 QIM é um método rápido e tem sido indicado como referência na padronização e harmonizạ̧̃̃o da avaliação sensorial do pescado na Europa Estes autores ainda sugerem uma relaģào linear entre o QIM e o tempo de estocagem em gelo para diversas espécies de pescado, sendo uma ferramenta prática, objetiva e poderosa para a indústria da pesca. ESTEVES e ANIBAL (2007) também indicaram o QIM como ferramenta para o estabelecimento da vida útil do pescado, uma ver que os resultados do QIM estão linearmente relacionados com o tempo de conservação.

$\mathrm{O}$ s consumidores, cada vez mais exigentes quanto a qualidade dos alimentos, também determinam a aceitação e/ou rejeição do pescado e produtos derivados sensorialmente (MARTINSDÓTTIR et al., 2001). Por esta raxão, faz-se extremamente útil o desenvolvimento de métodos que descrevam as propriedades sensoriais do alimento, caracterizando os atributos iniciais e as principais mudangas que ocorrem 20 longo da estocagem (HUIDOBRO of al., 2000).

Segundo HYLdig e NIELSEN, (1997) e NUNES e BATISTA (2004), as vantagens do QIM requerer treinamento simples, ser rápido, nãodestrutivo e objetivo. Nenhum atributo tem peso excessivo na classificação final e quanto maiores forem as alteraçoes em determinada caracteristica. derivadas da deterioração do pescado, maior será a classificação atribuida, podendo ser utilizado como ferramenta no planejamento a produção e na sarantia da qualidade. No entanto, o QIM deve ser desenvolvido para cada espécie, o que se pode ser considerado uma desvantagem.

Com vistas a assegurar a seguranga alimentar na cadeia produtiva do camarão marinho é importante a manutenção da alta qualidade em cada elo desta complexa cadeia produtiva, da captura 20 sarfo do consumidor. Prevé-se que o QIM será útil para dar sabarito aos pescadores a respeito da qualidade da sua captura, o que poderá influenciar positivamente a manipulação a bordo das embarcagóes pesqueiras (BONILLA ef al., 2007).

\section{CONSIDERAÇÕES FINAIS}

A presente revisão permite-nos concluir que:

- no panorama de mercado atual não há espaço para produtos alimenticios com qualidade deficiente e/ou duvidoss;

- o camarão sete-barbas comercializado no litoral paulista necessita de um controle de qualidade criterioso;

- a melhoria da qualidade do camarão é sarantia de valoração do produto, uma vez que há mercado sarantido para produtos de camarão de boa qualidade, com consequente melhoria as condiģóes de vida para um srande número de profissionais envolvidos na atividade;

- o treinamento dos profissionais da pesca do camarão em Boas Práticas de Manipulação pode mellhorar a qualidade dos camarões desembarcados e comercializados no litoral paulista, principalmente quanto ao aspecto $\mathrm{d} a$ sanidade;

- é iminente o desenvolvimento de padrões de qualidade especifico para o camarão sete-barbas visando a garantia da qualidade;

- há necessidade de implementar programas de sestão da qualidade para o camarão setebarbas, sobretudo avançar quanto à certificação na orisem, que é imprescindivel para a sarantia da seguranģa do consumidor; neste sentido, também o monitoramento sanitário das áreas de pesca ferramenta fundamental;

- é oportuna a realização de estudos que viabilizem a formulação de normas e/ou regulamentos para a espécie em questão, bem 
como, - desenvolvimento de ferramentas de padronização rápida, efetiva e viável, o que poderá contribuir positivamente para com o trabalho dos técnicos da inspeção e/ou do controle de qualidade;

- o consumidor atual busca maior qualidade seguranģa na sua alimentaģão, ressaltando a importáncia da qualidade dos produtos pesqueiros como valor agrezado;

- QIM parece ser uma ferramenta promissora para se avançar na mellhoria da qualidade do camarão sete-barbas ofertado no litoral de São Paulo.

\section{REFERÊNCIAS}

ABBAS, K.A; MOHAMED, A.; JAMILAH, B. EBRAHIMIAN, M. 2008 A review on correlations between fish freshness an pH during cold storage. American Joumal of Biochomistry and Biotochnology. EUA, 4(4): 416-421.

ÁvILA-DA-SILVA A.O.; CARNEIRO, MH MENDONÇA, J.T;; SERVO, G.J.M; BASTOS, G.C.C.: SILVA S.O.: BATISTA, P.A. 2005 Produção pesqueira marinha do estado de São Paulo no ano de 2004. Sóris Relatórios Tócnicos, n.20. Sào Paulo: Instituto de Pesca/APTA/SAA.40p.

BADIANI, A.; ADINOLFI, F.; BONALDO, A. FAGIOLI, P.; FCQCHI, C.; TESTI, S.; GATTA, P. 2009 Froshness Assossment of Europoan Hinko, Chub Machorol and Horso Mackaral. Bologna: Libreria Bonomo Editrice. 170p.

BEKAERT, K. 2006 Development of Quality Index Method scheme to evaluate freshness of tub sumard (Chalidonichthys lwoornus). In: LUTEN, J.B.; JACOBSEN, C.; BEKAERT, K.; S,FBO, A. OEHLENSCHLAGER, J. Sanfood resourch from fish to dish. Wageningen: Wageningen Academic Publishers. p.289-296.

BONILLA, A.C:- SVEINSOTTIR K.; MARTINSDOTIIR, E. 2007 Development of Quality Index Method (QDM) scheme for fresh cod (Gadus mornua) fillets and application in shelf life study. Food Control, England, UK, 18(4): 352-363.

BOTTA, J.R. 1996 Exaluation of soafood froshness quality. New York vCH Publisher. 180p.

BRAsIL. 1952 Ministério da Agricultura. Rogulamanto do Inspoção Industrial a Santiária de Produtos do
Origam Animal (R.I.I.S.P.O.A). Decreto n. 30.691 de 29 de março de 1952, Diário Oficial da União, 07/07/1952, Seção 1, Capitulo 7 - Pescados e Derivados. p.71- 73 .

BRASIL 1977 Ministério da Saúde. Agência Nacional da Vigilância Sanitária. Resoluçĩo Comissão Nacional de Normas a Padröes para Alimonios CNNPA n.14, de 15 de jullho de 1977. Disponivel em: Shttp///www-anvisa.gov.br/legis/resol/ 14_77.htm> Acesso em: 31 jul. 2008.

BRASIL. 2001 Ministério da Saúde. Agéncia Nacional da Vigilância Sanitária. Resolução $\operatorname{RDC~n} 12$, de 2 de janeiro de 2001. Rogulamento tóconico sabro padröss microbialógicos am alimentos. Disponivel em: <http://www anviza.gov/legis/resol_/1201 redchtm> Acesso em: 27 a50. 2009.

BRASIL 2005 Ministério do Meio Ambiente. Conselho Nacional do Meio Ambiente - CONAMA. Qualidado da água. Resolução 357, de 17 de março de 2005. Disponivel em <wwwingaba. sov.br/common/fckeditor/editor/.../php/transf er.php?._> Acesso em: 31 jul. 2009.

BREMNER, H.A. 1985 A convenient, exsy-to-use system for estimating the quality of chilled seafood. Fish Procossing Bullotin, San Diego, 7: 59-70.

BREMINER, H.A.; OLLEY, J.; VAI, A.M.A. 1987 Estimatins time temperature effects by a rapid systematic sensory method. In: KRAMER, D.E: LISTON, J. Sonfood Quality Detormination, Dovalopments in Food Scionce. Ansterdam, The Netherlands: Elsevier Science Publishers. v.15, p.415- 435 .

CYPRIAN, O.O; SVETNSDOTIIR, K. MAGNUS90ON, H; MARTINSDOTIIR, E. 2000 Application of Quality Index Method (QDM) scheme and effects of short-time temperature abuse in shelf life study of fresh water Arctic Char (Salevlinus alpinus). Jow of Aqual ofic Food Product Tochnology, London, 17(3): 303-321.

ESTEVES, E. e ANIBAL, J. 2007 Quality Index Method (QIM): utilização da Análise Sensorial para determinação da qualidade do pescado. In: CONGRESSO DO ALGARVE, 13., Lagos, 1517/nov./2007. Actas detronica... p.365-373. Disponivel em: <http://w3.uals.pt/-eesteves /docs/ArtigoonM_13CongressoAlsarve_Esteves Anibal.pdf> Acesso em: 23 out. 2009. 
EUA. 1992 National Advisory Committee on Microbial Criteria for Foods - NACMCF. Hasard analysis critical control point system. Intornational Jowmal of Foad Micrabiology, Torino, 16: 1-23.

FAO. 2007 Capture production 1950-2006. FISHSTAT Plus - Unviversal softwowe for fishery statistical timo sorics. Disponivel em: <http: //www fao.ors/fishery/topic/16073> Acesso emr 27 out 2009 .

FAO. 2008 Food Agriculture Organization of the United Nations. The State of World Fishories and Aquaculture - Sofia. Rome: Fisheries and Aquaculture Department. Disponivel em: 〈http://www.fao.or: > Acesso em: 27 out. 2009.

FURLAN, E.F. e TORRES, E.A.F.S. 2010 Seguranga alimentar na cadeia produtiva do camarão setebarbas (Xiphoponaews kroyari). In: SLMPÓsIO DE CIÊNCLA E TECNOLOGIA DE ALIMENTOS, 2.: CONGRESSO DO INSTITUTO NACIONAL DE FRUTOS TROPICAIS, 1., Aracaju, SE, 1821/abr./2010. Anais... (ISBN: 978-85-63641-00-7)

GERMANO, PM.L.; GERMANO, M.IS; OLIVEIRA C.A.F. 2008 Qualidade do pescado. In GERMANO, PMLL e GERMANO, MIS. Higiene - vigilância sanitária dos alimentos, J'ed. Cap. 8. Barueri, SP:- Manole. p.161-177.

GONCALVES, A.C.; ANTAS, S.E.; NUNES, M.I 2007 Freshness and quality criteria of iced farmed Senegalese sole (Solon sonogalonsis). Journal of Agriculfural and Food Chomistry. Califórnia, 55: 3452-3461.

GRAÇA LOPES, R.; SANTOS, E.P. DOS; SEVERMNORODRIGUES, E.; BRAGA, F.MS.; PUZZI, A 2007 Aportes ao conhecimento da biologia pesca do camarão-sete-barbas (Xiphoponaous kroyeri Heller, 1862) no litoral do Estado de São Paulo, Brasil. Bolotions do Instituto de Posca, Sào Paulo, 33(1): 63-84.

GUILLERM-REGOST, C.; HAUGEN, T.; NORTVEDT, R.; CARLEHÖG, M.; LUNESTAD, B.T.; KIESSLING, A.; RORA, A.M.B. 2006 Quality Characteriation of Farmed Atlantic Halibut During Ice Storage. Joumal of Food Scioncs, Chicaso, $71(2): 83-90$.

HORTON, L. R; WRIGHT, B., WRIGHT, E. 2008 International Food \& Agricultural Trade Policy Council. IPC Position Paper - Standards Series. Disponivel em: <hitp://www.agritrade.org/
Publications/documents/IPCStandardsPosition Paper.pdf> Acesso em: 20 out 2009.

HUIDOBRO, A.; PASTOR, A.; TEJADA, M. 2000 Quality index method developed for raw silthead seabream (Sparus aurata). Joumal of Food Scionce, Chicaso, 65: 1202-1205.

HUSs, H.H. 1996 Quality and quality changes in fresh fish. FAO Fishorias Inchenical Papor 348, Rome: FAO. 195 p.

HUSs, H.H. 1997 Garantia da qualidade dos produtos da pesca. FAO Documento T́́cnico sobre as Pesciss nf 334, Romx: Fisheries and Aquaculture Department. 176p.

HUSS, H.H.; ABABOUCH, L.; GRAM, L. 2004 Assessment and management of seafood safety and quality. FAO Fishorios Tochical Paper 444, Rome: FAO. 266p.

HYLDIG, G. e NIELSEN, J. 1997 A rapid sensory method for quality management. In OLAFSDÓTTIR G.; LUTEN, J.; DALGAARD, P; CARECHE, M.; VERREZ-BAGNIS, E; MARTINSDÓTTIR E; HEIA, K (eds) Mothods to Detormine the Froalmoss of Fish in Resoarch and Industry. Procondings of the Final Mooting of the Concorted Action Evaluation of Fish Froshmoss, Paris: International Institute of Refrigeration. p.297-306.

INSTITUTO DE PESCA 2011 Informe da Produção Pesqueira Marinha e Estuarina do Estado de Sào Paulo: Julho 2011. Centro APTA Pescado Marinho, Instituto de Pesca, Santos, 12(set. 2011):4p

MACHADO, T.M.; FURLAN, É.F.; NEIVA, C.R.P. CASARINI, L.M.; ALEXANDRINO DE PEREZ, A.C.; LEMOS NETO, M.J.; TOMITA, RY. 2010 Fatores que afetam a qualidade do pescado na pesca artesanal de municípios da costa sul de Săo Paulo, Brasil. Bolotim do Instifufo do Pesca Sào Paulo, 36(3): 213-223.

MACHADO, R.MD; TOLEDO, M.C.F.; VICENTE, E. 2006 Sulfitos em alimentos. Brazilian Journal of Food Tochnology, Campinas, 9(4): 265-275.

MARTINSDÓTTIR, E; SVENNSDÓTTIR, K; LUTEN, J.B.; SCHELVIS-SMIT, A.A.M.; HYLDIG, G. 2001 Sonsory crualuation of fish froshoss. Reference manual for the fish sector, The Netherlands: QIM Eurofish. p.49.

Bol. Insti. Pascn, São Paulo, 37(3): 317 - 326, 2011 
MARTINSDÓTTIR, E.; LUTEN, J.B.; SCHELVISSMIT, A.A.M; HYLDIG, G. 2003 Development of QIM - past and future. In: LUTEN, J. OEHLENSCHLAGER, J- OLAFSDOTTIR, G. (eds) Quality of fish from catch to consumer: Labelling, Monitoring and Traceability. The Netherlands: Wageningen Academic Publishins. 1: $265-272$.

MORA15, C. 1984 Causa e prevenção da "mancha neğra" em camaróes. Bolatim do ITAL, Campinas, 21(2): 121-135.

MOURA, A; DEL BEN MAYER, M.; LANDGRAF, M.; TENUTA FILHO, A. 2003 Qualidade quinica e microbiológica de camarão-rosa comercializado em São Paulo. Brazilinn Journal of Pharnacoutical Scioncos, São Paulo, 39(2): 203-208.

NUNES, AJ.P. 2001 O cultivo de camarṍes marinhos no Nordeste do Brasil Panorama da Aquicicultura Rio de Janeiro, 11: 29-33.

NUNES, M.L. e BATISTA, I. 2004 Aplicação do indice de qualidade (QMM) na avaliação da frescura do pescado. Divulgugaio IPIMAR, Algés. Disponivel em: <http://ipimar-iniap.ipimar.pt/ servicos/biblioteca/edicoes/ipimar-divulgacao/ Folheto29.pdf> Acesso em: 20 out. 2009.

OGAWA, M. e DINIZ, F.M. 1999 Tecnologia do pescado na região nordeste. In OGAWA, M. e MAIA, E.L. Mnnual da posca. v.1, São Paulo: Varela. p.398-410.

OGAWA N.B.P.; ARAÜJO, I.W.F.; LUCENA. L.H.L. MAIA, E.L.; OGAWA, M 2003 Teor residual de $\mathrm{SO}_{2}$ em camarões congelados exportados pelo Estado do Ceará. Bolotim Tócnico do CPNOR, Belém, 3(1): 191-196.

OTWELL, W.S. e FLICK Jr., G.J. 1996 A HACCP program for naw, culturod Ponaid shrimp. Florida: Florida Sea Grant College Program p.218-226.

PẢDUA, H.B. de. 2003 Informagōss sobre os coliformes totais/ focnis o nlguns outros organisnos indicadores om sistomas mquáticos - Aquicultura. 20p. Disponivel em: <http://www.setorpesqueiro. combr> Acesso em: 12 aso. 2009

PAIVA, R.I.; RODRIGUES, J; AMORIM, L.A. 200 Carcinioulfura Brasileira on 2003. Disponivel em: <http://www.abccam.com.br/download/carcio 3.pdf> Acesso em: 10 out. 2005.
PINHEIRO, J.S. e CINTRA, IH.A. 1999 Tecnologia do pescado na Reģião Norte. In: OGAWA, M e MAIA E.L. (orst). Manual do Pesca. v.1, São Paulo: Livraria Varela. p.411-419.

PONS-SÁNCHEZ-CASCADO, S; VIDAL-CAROU, M.C.; NUNES, M.L.; VECLANA-NOGUÉS, M.T. 2006 Sensory analysis to assess the freshness of Mediterranean anchovies (Engraulis oncrasicholus) stored in ice. Food Contral, United Kingdom, 17: 564-569.

SEVERNO-RODRIGUES, E.; PITA. J.B.; GRAÇALOPES, R; COELHO, J.A.P.; PUZZI, A 1993Aspectos biológicos e pesqueiros do camarào-sete-barbas (Xuphoponaous kroyori) capturado pela pesca artesanal no litoral do Estado de São Paulo. Bolotims do Instituto do Pesca, Săo Paulo, 19: 67-81.

SCHRŌDER, U. 2008 Challenges in traceability of seafood. Journal für Verbraucherschutz wnd Labungmittalsicherheit, Switwerland, 3(1): 45-48.

SYKES, A.V.; OLIVEIRA, A.R.; DOMINGUES, P.M: CARDOSO, CM; ANDRADE, JP.; NUNES, M.L. 2009 Assessment of Europexn cuttlefish (Sopia officinalis, L.) nutritional value and freshness under ice storage usins a developed Quality Index Method (QIM) and biochenuical methods. LWT - Food Science and Tochology. Zurich, 42: 424-432.

THAMIPURAN, N. e GOPAKUMAR, K. 1990 Impinct of handling practices on the micrabial quality of shrimp (Motaponacus dobsoni). Rome: FAO Fisheries Report 401, p.47-52.

YASUADA, T. e BOWEN, RE. 2006 Chain of custody $\alpha s$ an organizins framework in seafood riak reduction. Marine Pollution Bullotien, United Kingdom, 53: 640-649.

YOKOYAMA, VA. 2007 Qualidado do camañ̃o de eppócio Xyphopentaens kroyeri medianto a agnōo dos agontes antimolanóticos. Piracicaba. 124p. (Dissertação de Mestrado, Departamento de Agroindústria, Alimentos e Nutrição, Escola Superior de Agricultura Luiz de Queiroa, Universidade de São Paulo). Disponivel em: Shttps//www.teses.usp.br/teses/disponiveis/11 /11141/tde-28022008-154048/pt-br.php> Acesso em: 18 set. 2011. 
Anexo 2 - Capa do Livro publicado em novembro/2012 - Capítulo 6 - Manuscrito 2

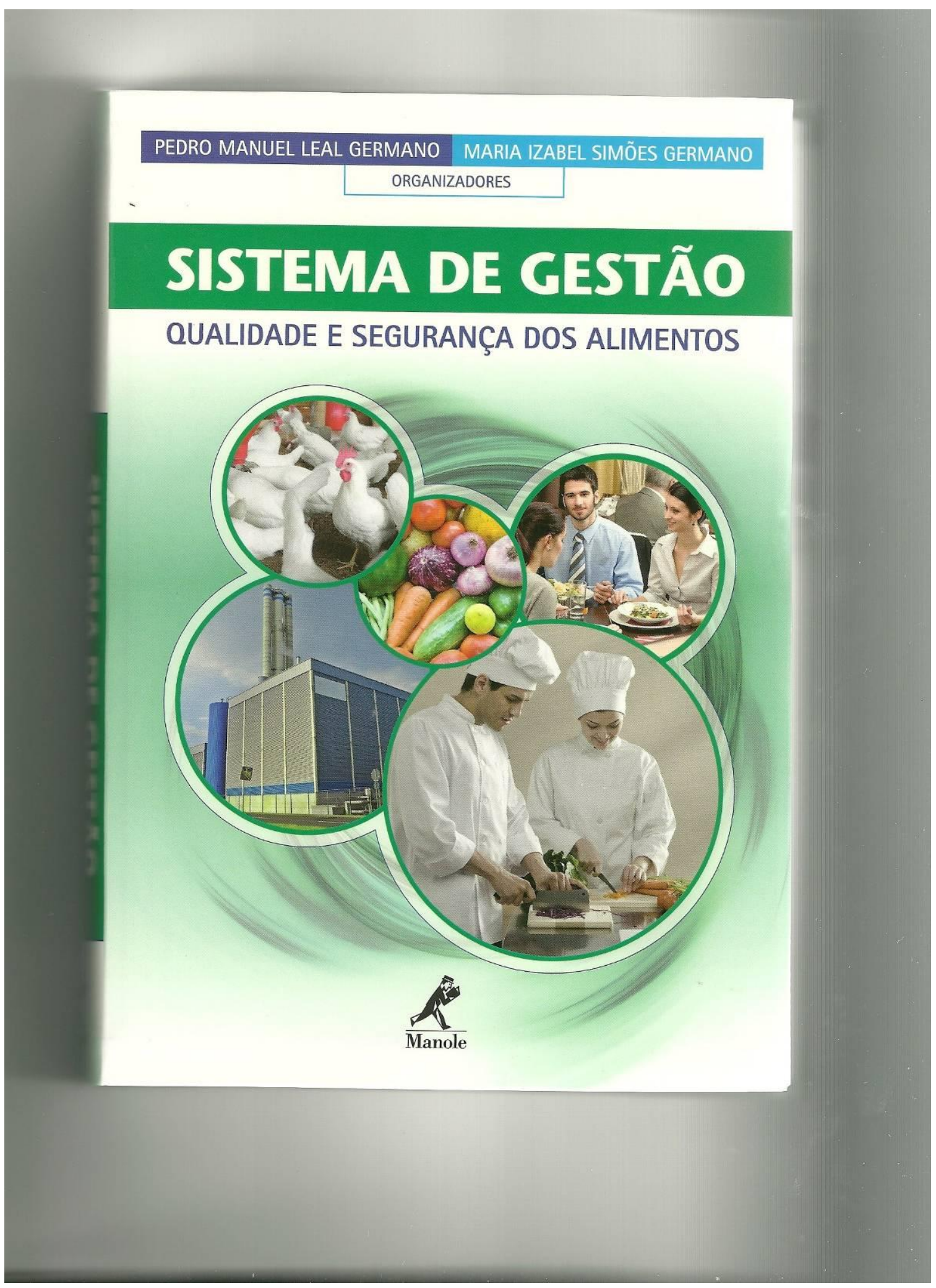


Anexo 3 - Ficha da análise sensorial de aceitação do camarão sete-barbas in natura.

Nome: Idade:

Amostra:

APARÊNCIA:
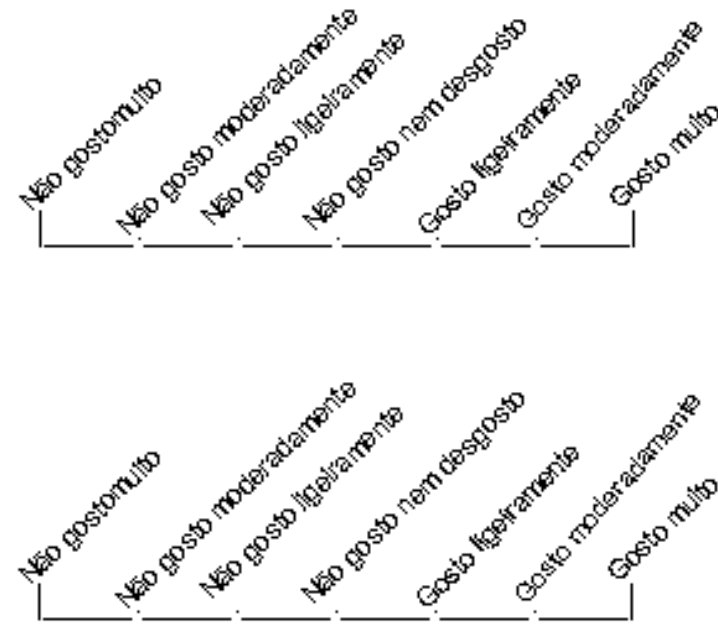

COR:

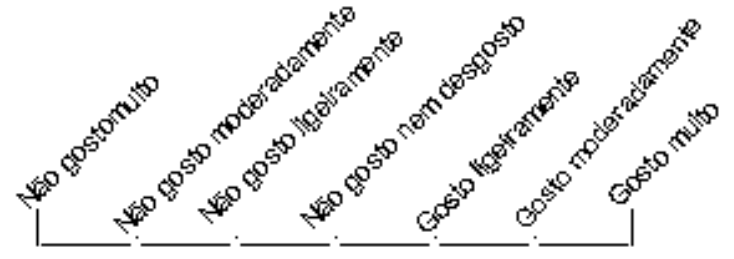

ODOR:

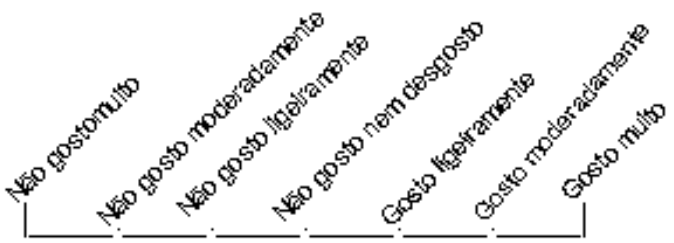

TEXTURA:

Indique o que você mais gostou e o que menos gostou neste produto:

+ Gostei:

- Gostei:

Você compraria este produto? ( ) sim ( ) não 
Anexo 4 - Ficha de análise sensorial de camarões sete-barbas cozido.

\section{Ficha de Avaliacão Sensorial Descritiva do camarão sete-barbas cozido}

Nome:

Data:

Por favor, prove a amostra __ e assinale a intensidade dos atributos na tabela a seguir:

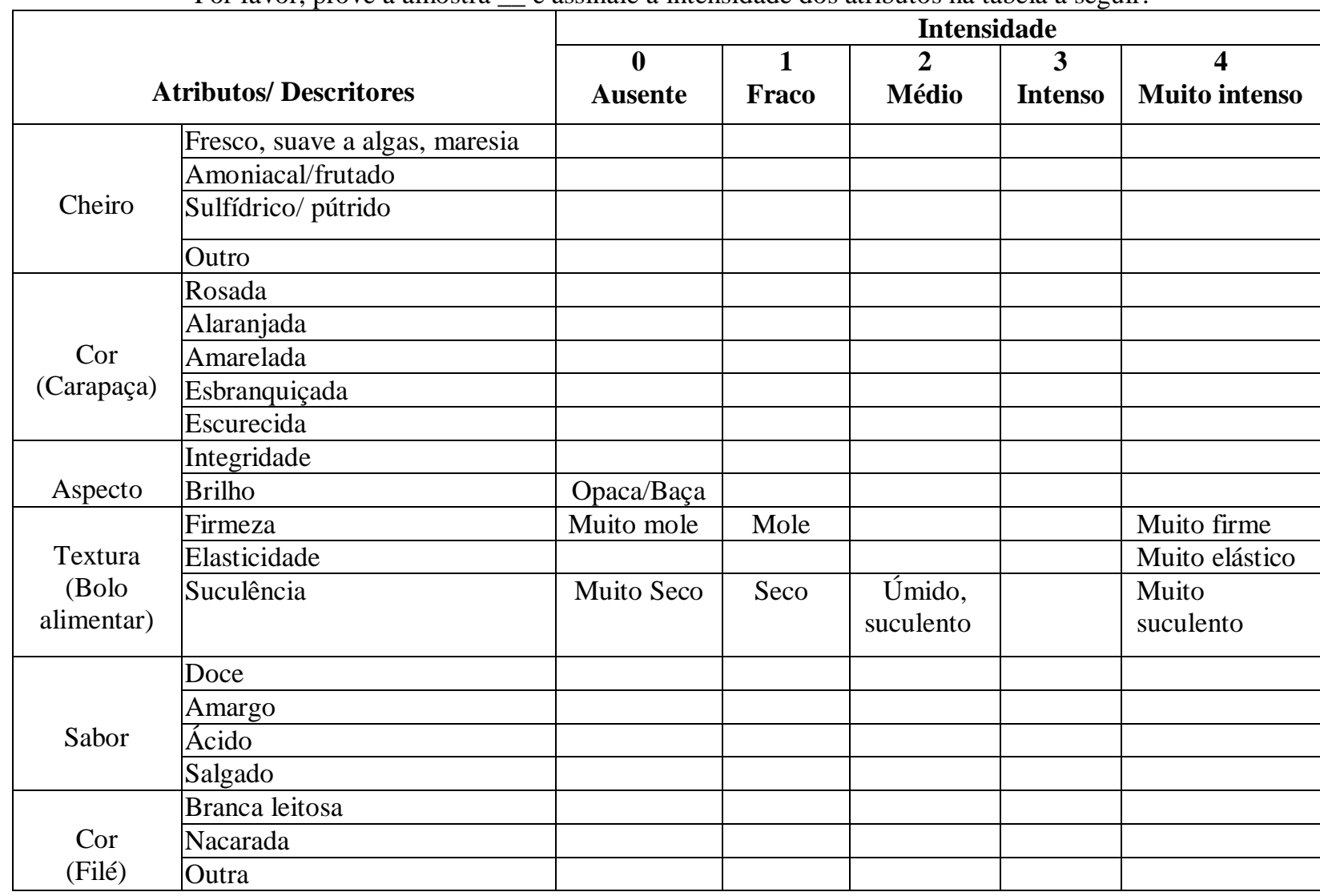

Apreciação global (Assinale com $\mathbf{X})$ :

\begin{tabular}{|c|c|c|c|c|c|c|}
\hline $\begin{array}{c}\text { Não gosto } \\
\text { nada }\end{array}$ & $\begin{array}{c}\text { Não gosto } \\
\text { moderadamente }\end{array}$ & $\begin{array}{c}\mathbf{2} \\
\text { Não gosto } \\
\text { ligeiramente }\end{array}$ & $\begin{array}{c}\text { Não gosto } \\
\text { nem } \\
\text { desgosto }\end{array}$ & $\begin{array}{c}\mathbf{4} \\
\text { Gosto } \\
\text { ligeiramente }\end{array}$ & $\begin{array}{c}\mathbf{5} \\
\text { Gosto } \\
\text { moderadamente }\end{array}$ & $\begin{array}{c}\mathbf{6} \\
\text { Gosto } \\
\text { muito }\end{array}$ \\
\hline & & & & & \\
\hline
\end{tabular}

Por favor, indique os atributos que mais contribuíram para a sua apreciação:

Muito obrigada pela sua colaboração! 
Anexo 5 - Parecer do comitê de Ética

\section{COMITE DE ETICA EM PESQUISA - COEP}

Faculdade de Saúde Publica

Universidade de São Paulo

OF.COEP $/ 123 / 12$

04 de junho de 2012

Prezadas pesquisadora e orientadora,

O Comité de Etica em Pesquisa da Faculdade de saude pública da Universidade de São Paulo, em sua $5: 12$ sessáo ordinária, realiząa em $11 / 05 / 2012$, analisou de acordo com a Resolução n $\bullet 196 / 96$ do Conselho Nacional de Saude e suas complementares, o protocolo de pesquisa 92027 intitulado QUALIDADE E PADRONIZACCÁO DO CAMARÁO SETE-BARBAS

(Xiphopeneus kroyeri) DESEMBARCADO NA BAIXADA SANTISTA, SP! do grupo III sob responsabilidade da pesquisadora Erika Fabiane Furlan e orientação da Professora Elizabeth Aparecida Ferraz da Silva Torres, considerando APROV ADA a inclusão da degustação dos camaroes cozidos a $70^{\circ} \mathrm{C}$.

Cabe lembrar que, de acordo com a Res CNS 196,96, sao deveres do(a) pesquisador(a): 1) Comunicar de imediato qualquer alteração no projeto e aguardar manifestaçáo deste comitê de Ética em Pesquisa para dar continuidade a pesquisa, 2) Manter sob sua quarda e em local seguro, pelo prazo de 5 (cinco) anos, os dados da pesquisa, contendo fichas individuais e todos os demais documentos recomendados pelo GOEP no caso eventual auditoria, 3) Comunicar formalmente a este comité por ocasiáo do encerramento da pesquisa, 4) Elaborar e apresentar relatórios parciais e final, 5) Justificar perante o COEP intérupcáo do projeto ou a hão publicacáo dos resultados.

Atenciosamente,

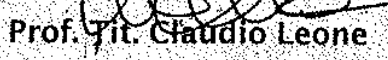

Coordenador do Comité de Etica em Pesquisa, FSP/USP 


\section{Anexo 6 - Primeira página do Currículo Lattes da aluna}

\section{Érika Fabiane Furlan}

- Endereço para acessar este CV: http://lattes.cnpq.br/1821513214759586

- Última atualização do currículo em 20/12/2012

Possui graduação em Zootecnia pela Universidade Estadual Paulista Júlio de Mesquita Filho (1999) e mestrado em Ciência e Tecnologia de Alimentos pela Escola Superior de Agricultura Luiz de Queiroz (2004). Atualmente é doutoranda em Nutrição em Saúde Pública pela Faculdade de Saúde Pública/USP e pesquisadora científica do Instituto de Pesca. Tem experiência na área de Ciência e Tecnologia de Alimentos, com ênfase em pescado, atuando principalmente nos seguintes temas: controle de qualidade do pescado e seguranca alimentar. (Texto informado pelo autor)

\section{Identificação}

\section{Nome}

Érika Fabiane Furlan

\section{Nome em citações bibliográficas}

FURLAN, É. F.

\section{Sexo}

Feminino

\section{Endereço}

\section{Endereço Profissional}

Instituto de Pesca, Centro APTA do Pescado Marinho - Instituto de Pesca.

Av. Bartolomeu de Gusmão, 192

Ponta da Praia

11030-906 - Santos, SP - Brasil

Telefone: (13) 32612653

Fax: (13) 32611900

URL da Homepage: http://www.pesca.sp.gov.br

\section{Formacão acadêmica/titulacão}

2009

Doutorado em andamento em Nutrição em Saúde Pública.

Faculdade de Saúde Pública da Universidade de São Paulo.

Título: QUALIDADE E PADRONIZAÇÃO DO CAMARÃO-SETE-BARBAS (Xiphopenaeus

kroyeri) DESEMBARCADO NA BAIXADA SANTISTA, SP,

Orientador: Elizabeth Aparecida Ferraz da Silva Torres.

\section{1 - 2004}

Mestrado em Ciência e Tecnologia de Alimentos.

Escola Superior de Agricultura Luiz de Queiroz.

Título: Vida útil dos mexilhões Perna perna cultivados no litoral Norte de São Paulo: aferição dos parâmetros físico-químicos e microbiológicos., Ano de Obtenção: 2004.

Orientador: Marília Oetterer.

Bolsista do(a): Coordenação de Aperfeiçoamento de Pessoal de Nível Superior, CAPES, Brasil. 


\title{
Anexo 7 - Primeira página do Currículo Lattes da orientadora
}

\section{Elizabeth Aparecida Ferraz da Silva Torres}

\author{
Bolsista de Produtividade em Pesquisa do CNPq - Nível 2 \\ - $\quad$ Endereço para acessar este CV: http://lattes.cnpq.br/9804923403746874 \\ - Última atualização do currículo em 14/09/2012
}

Elizabeth Aparecida Ferraz da Silva Torres concluiu o Doutorado em Ciência dos Alimentos (São Paulo, SP) pela Universidade de São Paulo, em 1988. Foi Visiting Scholar na MSU de 1986 a 1987, como bolsista Fulbright Comission. Professora Associada - desde 2000 na Faculdade de Saúde Pública da Universidade de São Paulo. Publicou 89 artigos em periódicos especializados e 126 trabalhos em anais de eventos. Possui 4 livros publicados, 1 processo, 1 software e 1 patente técnica além de outros 30 itens de produção técnica. Participou de 11 eventos no exterior e 78 no Brasil. Supervisionou 1 pós-doutor com bolsa da FAPESP e supervisiona um Jovem Pesquisador com auxílio e bolsa da FAPESP. Orientou 23 dissertações de Mestrado, 14 teses de Doutorado e co-orientou 1 tese de Doutorado, em complemento orientou 22 trabalhos de Iniciação Científica nas áreas de Ciência e Tecnologia de Alimentos, Nutrição e Saúde Coletiva. Vários AT foram treinados. Recebeu 6 Prêmios/Homenagens. Atua diretamente na área de Ciência e Tecnologia de Alimentos com ênfase em quatro linhas de pesquisa: 1) Lipídios, ácidos graxos, colesterol, fitoesterol e seus produtos de oxidação. 2) Antioxidantes e substâncias bioativas. 3) Carnes, Aves e Pescados 4) Microssomos, Lipossomos e Sistemas Modelo. Em suas atividades profissionais, interagiu com 165 colaboradores em co-autorias de trabalhos científicos. Em seu CVLattes, os termos mais frequentes na contextualização da produção científica, tecnológica e artístico cultural, são: aulas ministradas, comissões, grupos de trabalho, valor nutricional, segurança alimentar, lipídios, qualidade higiênico sanitária, substitutos de gordura, alimentos funcionais e tecnologia de alimentos. Em 09/09/2010 apresentou fator $\mathrm{H}=8$ na base SCOPUS. (Texto informado pelo autor)

\section{Identificacão}

\section{Nome}

Elizabeth Aparecida Ferraz da Silva Torres

Nome em citações bibliográficas

TORRES, E. A. F. S.;;Torres, Elizabeth Aparecida Ferraz Da Silva;Torres, Elizabeth A. F. S.

\section{Sexo}

Feminino

\section{Endereco}

\section{Endereço Profissional}

Universidade de São Paulo, Faculdade de Saúde Pública, Departamento de Nutrição.

Av. Dr. Arnaldo, 715 HNT

Cerqueira César

01246-904 - Sao Paulo, SP - Brasil

Telefone: (11) 30617857

Fax: (11) 30617130

URL da Homepage: www.fsp.usp.br/ eatorres/ 